UNIVERSIDADE DE BRASÍLIA

FACULDADE DE CIÊNCIAS DA SAÚDE

RENATA PAULA COPPINI DE ALMEIDA

AVALIAÇÃO DA PRODUÇÃO DE L- ASPARAGINASE POR FUNGOS ISOLADOS DO BIOMA CERRADO

BRASÍLIA-DF 
Dissertação de Mestrado apresentada ao Programa de Pós-Graduação em Ciências Farmacêuticas da Faculdade de Ciências da Saúde, Universidade de Brasília, como requisito parcial à obtenção do título de Mestre em Ciências Farmacêuticas.

Orientador(a): Prof(a). Dra(a). Pérola de Oliveira Magalhães Dias Batista 
RENATA PAULA COPPINI DE ALMEIDA

\section{AVALIAÇÃO DA PRODUÇÃO DE L-ASPARAGINASE POR FUNGOS ISOLADOS DO BIOMA CERRADO}

Dissertação de Mestrado apresentada ao Programa de Pós-Graduação em Ciências Farmacêuticas, Faculdade de Ciências da Saúde, Universidade de Brasília, como requisito parcial à obtenção do título de Mestre em Ciências Farmacêuticas.

Aprovada em 05 de março de 2015.

\section{Banca examinadora}

Profa. Dra. Pérola de Oliveira Magalhães Dias Batista

Faculdade de Ciências da Saúde da Universidade de Brasília (UnB)

Profa. Dra. Maria de Fátima Borin

Faculdade de Ciências da Saúde da Universidade de Brasília (UnB)

Profa. Dra. Eliete Neves da Silva Guerra

Faculdade de Ciências da Saúde da Universidade de Brasília (UnB) 
"Nem tão longe que eu não possa ver, nem tão perto que eu possa tocar, nem tão longe que eu não possa crer, que um día chego lá".

Humberto Gessinger 
Ao mew amado esposo Bruno, pelo sew carinho e compantheirismo incondicionais.

Aos mens pais Renato e Magda, pelo amor e dedicação recebidos.

Ao men irmão Matens, pela amizade $e$ palarras de apoio. 


\section{AGRADECIMENTOS}

A Deus, por mais essa etapa vencida em minha vida.

A Professora Dra. Pérola de Oliveira Magalhães Dias Batista, pela oportunidade, confiança e amizade. Seus estímulos, apoio e questionamentos foram fundamentais para a conclusão desse trabalho. Muito obrigada.

Ao meu maior incentivador, companheiro de todas as horas, meu amor Bruno. Obrigada pelo carinho, compreensão, apoio e paciência neste período e em todos os momentos da minha vida. Amo muito você.

Aos meus pais, Renato e Magda, e ao meu irmão, Mateus, que, mesmo distantes, incentivam e compartilham os grandes momentos da minha vida. Sem vocês, nada disso seria possível.

A toda minha família que sempre torceu muito pelas minhas conquistas, especialmente a minha tão amada avó, Maria, que sempre me protege e abençoa em suas orações.

As professoras Dra. Maria de Fátima Borin e Dra. Eliete Neves da Silva Guerra, por terem aceitado o convite e participarem como membros da banca de avaliação deste trabalho. Meus sinceros agradecimentos pela atenção dispensada.

Aos professores Dra. Damaris Silveira, Dra. Yris Fonseca e Dr. Maurício Homem de Mello pelos ensinamentos e pelo apoio na realização das minhas atividades.

Ao professor Dr. Edivaldo Ximenes Ferreira Filho e ao grupo de estudo do Laboratório de Enzimologia do Instituto de Ciências Biológicas da Universidade de Brasília pelos ensinamentos e suporte que permitiram a execução de atividades que foram essenciais neste trabalho.

Ao professor Dr. Adalberto Pessoa Junior pelo apoio e suporte durante a realização deste trabalho.

A todos os professores do Programa de Pós-Graduação em Ciências Farmacêuticas da UnB pelo apoio, colaboração e ensinamentos. 
Aos colegas e amigos do Laboratório de Controle da Qualidade de Fármacos e Medicamentos; Carol, Christian, Dani, Diegue, Ekaly, Gabi, Juli, Kleber, Lorena, Luana, Marcela, Márcia, Marline, Michelle, Mona, Nathália, Pati, Paula, Rachel, Raquel, Rodrigo, Samuca e Yuri, que tanto contribuíram na execução deste trabalho. Além disso, meu muito obrigada pelas palavras de apoio e incentivo nos momentos mais difíceis, serei eternamente grata por tudo.

À CAPES pelo suporte financeiro concedido.

A todas as pessoas que direta ou indiretamente contribuíram para o desenvolvimento e conclusão deste trabalho, meu muito obrigada. 


\section{RESUMO}

ALMEIDA, Renata Paula Coppini de Almeida. Avaliação da produção de LAsparaginase por fungos isolados do bioma Cerrado. Dissertação (Mestrado em Ciências Farmacêuticas) - Faculdade de Ciências da Saúde, Universidade de Brasília, Brasília 2015.

A leucemia linfóide aguda (LLA) é uma neoplasia maligna de linfócitos, caracterizada pelo acúmulo de células sanguíneas imaturas na medula óssea. Um dos medicamentos utilizados no tratamento da LLA é a enzima L-Asparaginase. Algumas linhagens de células tumorais não são capazes de produzir asparagina, assim, a redução dos níveis plasmáticos do aminoácido implica na inibição da síntese de proteínas das células leucêmicas. Atualmente, estão disponíveis apenas enzimas de origem bacteriana para serem utilizadas na clínica, o que reflete na grande taxa de efeitos adversos relacionados ao tratamento. Neste sentido, a busca por novas fontes de L-Asparaginase torna-se imprescindível. O presente trabalho teve como objetivo principal avaliar a produção de L-Asparaginase por fungos filamentosos isolados do bioma Cerrado brasileiro. Inicialmente, foi realizada a padronização do preparo da amostra e da metodologia para determinação da atividade enzimática, onde foram utilizadas a enzima padrão (Sigma-Aldrich) e a cepa de um conhecido produtor de L-Asparaginase, o Aspergillus terreus. Posteriormente, foram isolados 42 cepas fúngicas a partir do bioma Cerrado brasileiro. Das 42 cepas isoladas, 22 apresentaram halo vermelho, o que pode indicar a produção de L-Asparaginase. Essas 22 espécies foram cultivadas em meio líquido e apenas 10 apresentaram resultados positivos para produção enzimática. Em seguida, as 3 melhores cepas produtoras foram cultivadas em diferentes condições de cultivo a fim de melhorar a produção de L-Asparaginase. Com relação às fontes de carbono, a utilização de glicose foi essencial para a produção enzimática. A L-Prolina parece ser a fonte de nitrogênio mais eficaz para que a produção de L-Asparaginase ocorra. Foram encontrados ainda, diferentes valores de $\mathrm{pH}$ ótimos de cultivo pelas diferentes cepas fúngicas.

Palavras chaves: Asparaginase, Cerrado, fungos filamentosos, leucemia. 


\begin{abstract}
ALMEIDA, Renata Paula Coppini de Almeida. Evaluation of L-asparaginase production by isolated fungi of the savanna biome. Dissertação (Mestrado em Ciências Farmacêuticas) - Faculdade de Ciências da Saúde, Universidade de Brasília, Brasília 2015.
\end{abstract}

Acute lymphoblastic leukemia (ALL) is a malignant neoplasm of lymphocytes, characterized by the accumulation of immature blood cells in the bone marrow. One of the drugs used in the treatment of ALL is L-Asparaginase enzyme. Some tumor cell lines are not capable of producing asparagine thus the reduction of plasma levels of amino acids involves the inhibition of protein synthesis of leukemic cells. Currently, the only enzymes available for use in the clinic are of bacterial origin, which reflects the high rate of adverse effects related to treatment. In this way, the search for new sources of L-Asparaginase becomes indispensable. This study is aimed at evaluating the production of L-Asparaginase by isolated filamentous fungi of the brazilian savanna biome. Initially, the standardization of sample preparation was performed as well as the methodology for determining the enzymatic activity where the standard enzyme (Sigma-Aldrich) and the Aspergillus terreus, which is a known LAsparaginase strain producer, were used. Subsequently, 42 fungal strains from the brazilian savanna were isolated and a screening to assess the ability of the same for the production of L-Asparaginase was performed through the halo test. Out of the 42 isolated stains, 22 species showed red halo, which may indicate the production of LAsparaginase. These 22 species were cultivated in the liquid medium under controlled agitation and temperature and only 10 were positive for enzyme production. Then, the top 3 producing strains were grown in different culture conditions to improve the production of L-Asparaginase. Regarding the carbon sources, glucose utilization was essential for enzyme production. L-Proline seems to be the most effective source of nitrogen for producing L-Asparaginase. In addition, were found different optimum $\mathrm{pH}$ values of the different fungal strains cultivation.

Key words: Asparaginase, Brazilian Savanna, filamentous fungi, leukemia. 


\section{LISTA DE FIGURAS}

Figura 1 - Reação catalisada pela enzima L-Asparaginase .............................. 10

Figura 2 - Os 25 hotspots. As extensões de hotspot compreendem de 3 a 30\% das áreas vermelhas.

Figura 3 - Esquema simplificado do isolamento de fungos filamentosos do solo do bioma Cerrado da região Centro-Oeste brasielira.

Figura 4 - Amostras do caldo fermentado, após a realização de diferentes técnicas, a fim de eliminar a amônia formada durante o processo fermentativo em meio líquido. (A) Extrato bruto; (B) Amostra dialisada; (C) Amostra concentrada em membrana de ultrafiltração - 3,0 kDa; (D) Amostra ultrafiltrada em membrana de ultrafiltração - 3,0 kDa.

Figura 5 - Curva analítica de L-Asparaginase (Sigma-Aldrich).

Figura 6 - Cinética enzimática utilizando como amostra uma solução com concentração de $2 \mathrm{Ul} / \mathrm{mL}$ da enzima purificada (Sigma-Aldrich)

Figura 7 - Cinética enzimática utilizando como amostra a enzima de origem fúngica (filtrado da cultura dialisado), da cepa $A$. terreus (PC-1.7.A).

Figura 8 - Valores de atividade enzimática obtidos a partir de amostras dialisadas, de um único cultivo de $A$. terreus (PC-1.7.A), expostas a diferentes parâmetros de centrifugação. Todas as centrifugações foram realizadas durante 5 minutos.

Figura 9 - Valores de atividade enzimática obtidos a partir de soluções de concentrações conhecidas da enzima L-Asparaginase purificada (SigmaAldrich), utilizando diferentes concentrações de substrato durante a reação.......

Figura 10 - Valores de atividade enzimática, de amostra de cultivo de $A$. terreus (PC-1.7.A), utilizando diferentes concentrações de substrato durante a reação.

Figura 11 - Crescimento da cepa fúngica durante 7 dias, em dois meios líquidos de cultivo. A linha vermelha representa o crescimento em meio composto por glicose, L-Prolina e sais, enquanto a linha azul representa um meio que utilizou L-Asparagina, em substituição a L-Prolina, mais glicose e sais.

Figura 12 - Valores de $\mathrm{pH}$ final dos meios de cultivo, obtidos durante 7 dias da curva de crescimento. A linha vermelha representa o cultivo em meio composto por glicose, L-Prolina e sais, enquanto a linha azul representa um meio que utilizou L-Asparagina em substituição a L-Prolina. 
Figura 13 - Valores de proteína total produzida durante os 7 dias de cultivo. A linha vermelha representa o cultivo em meio composto por glicose, L-Prolina e sais, enquanto a linha azul representa um meio que utilizou L-Asparagina em substituição a L-Prolina.

Figura 14 - Valores de atividade enzimática de L-Asparaginase, durante os 7 dias de cultivo. A linha vermelha representa o cultivo em meio composto por glicose, L-Prolina e sais, enquanto a linha azul representa um meio que utilizou L-Asparagina em substituição a L-Prolina.

Figura 15 - Imagens das espécies vegetais utilizadas para o isolamento de fungos endofíticos. (A) Calophyllum brasiliensis; (B) Eriotheca pubescens; (C) Sapindus saponaria; (D) Eugenia dysentérica; (E) Erythroxylum daphnites.........

Figura 16 - Etapas do isolamento de fungos endofíticos. (A) Folhas da espécie vegetal Erythroxylum daphnites; (B) Fragmentos do material vegetal aplicado em placas de petri contendo o meio de cultura dextrose Sabouraud, onde já é possível a visualização de crescimento fúngico; (C) O fungo endofítico isolado..

Figura 17 - Formação de halo vermelho ao redor da colônia indicando a possível produção de L-Asparaginase pela espécie fúngica. Todas as figuras apresentam uma placa controle (esquerda) e uma placa teste (direita). (A) 24 horas de incubação; (B) 48 horas de incubação; (C) 72 horas de incubação; (D) 96 horas de incubação.

Figura 18 - Organograma geral dos fungos isolados do bioma Cerrado utilizados nesse trabalho.

Figura 19 - Cultivos realizados a fim de avaliar a produção enzimática frente a utilização ou não de pré-inóculo

Figura 20 - Valores de atividade enzimática de quatro cepas fúngicas, em cultivos realizados em meios líquidos com diferentes valores iniciais de $\mathrm{pH}$.

Figura 21 - Valores de atividade enzimática obtidos durante o cultivo em meio líquido, utilizando três fontes diferentes de nitrogênio. 


\section{LISTA DE TABELAS}

Tabela 1 - Metabólitos de importância para a indústria farmacêutica produzidos por fungos filamentosos.

Tabela 2 - Fontes de nitrogênio e de carbono utilizadas na composição do meio de cultivo CDM.

Tabela 3 - Valores de atividade enzimática obtidos a partir da utilização de solução de concentração conhecida da enzima L-Asparaginase $(1 \mathrm{Ul} / \mathrm{mL})$.........

Tabela 4 - Valores de atividade enzimática obtidos a partir de uma solução de concentração conhecida da enzima L-Asparaginase $(2 \mathrm{Ul} / \mathrm{mL})$, encontrados a partir da realização de duas diferentes metodologias.

Tabela 5 - Valores de absorbância encontrados antes e após a realização do processo de diálise.

Tabela 6 - Valores de atividade enzimática obtidos a partir de uma amostra dialisada, de um único cultivo de $A$. terreus, utilizando as diferentes metodologias propostas neste trabalho.

Tabela 7 - Valores (média das cinco repetições) de atividade enzimática obtidos a partir da realização das três metodologias, utilizando soluções com diferentes concentrações da enzima L-Asparaginase purificada (SigmaAldrich)

Tabela 8 - Valores (média das seis concentrações testadas) de precisão e exatidão obtidos para as três metodologias testadas

Tabela 9 - Valores obtidos para a precisão do protocolo da Microplaca, a partir da utilização de seis concentrações enzimáticas diferentes

Tabela 10 - Valores de exatidão obtidos a partir da execução da metodologia da Microplaca.

Tabela 11 - Espécies vegetais utilizadas para o isolamento de fungos endofíticos.

Tabela 12 - Fungos filamentosos isolados de diferentes regiões do solo do bioma Cerrado da região Centro-Oeste brasileira, utilizados neste trabalho.......

Tabela 13 - Vinte e dois isolados fúngicos que exibiram zona avermelhada em torno das colônias.

Tabela 14 - Produção enzimática de L-Asparaginase, em meio líquido, encontrada em dez dos vinte e dois isolados fúngicos testados. 
Tabela 15 - Valores de atividade enzimática e origem das três cepas de fungos filamentosos, isoladas do bioma Cerrado da região Centro-Oeste brasileira, que apresentaram melhores níveis de atividade de LAsparaginase. 


\section{LISTA DE ABREVIATURAS}
ANVISA - Agência Nacional de Vigilância Sanitária
BDA - Ágar batata dextrose
BSA - Soro albumina bovina
CMD - Czapek Dox modificado
CV\% - Coeficiente de variação
LLA - Leucemia linfóide aguda
LMA - Leucemia mielóide aguda
PEG - Polietilenoglicol
RDC - Resolução da Diretoria Colegiada
TCA - Ácido tricloroacético
TRIS - 2-Amino-2-hydroxymethyl-propane-1,3-diol 
1 INTRODUÇÃO

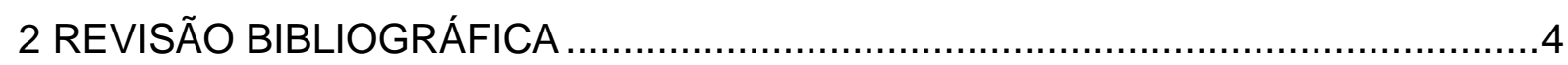

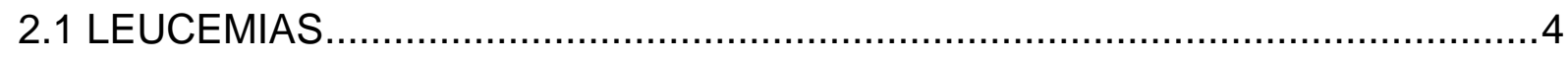

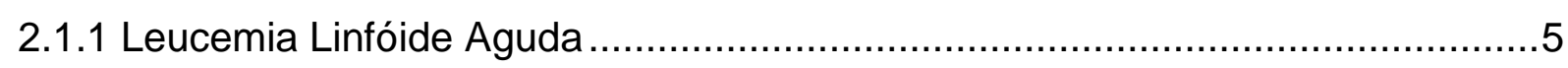

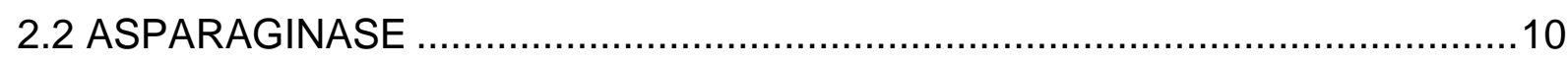

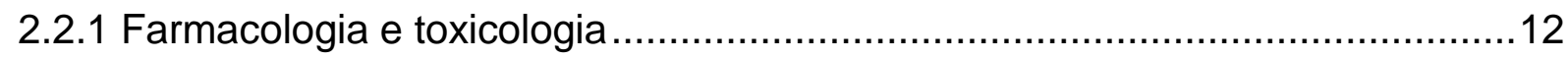

2.3 FUNGOS FILAMENTOSOS PRODUTORES DE ASPARAGINASE ..................15

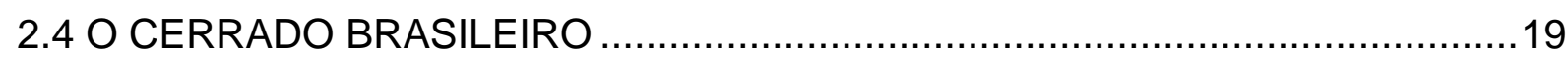

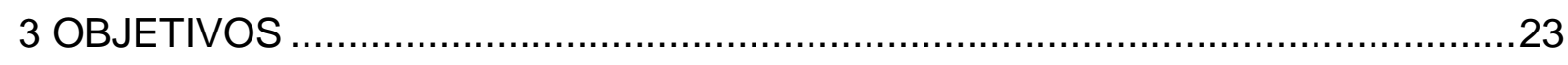

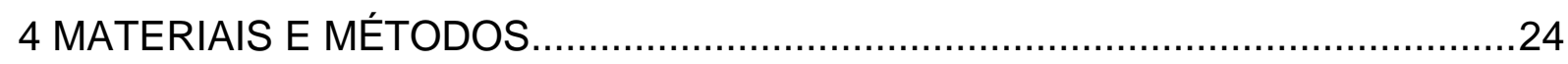

4.1 PADRONIZAÇÃO DA METODOLOGIA PARA A DETERMINAÇÃO DA

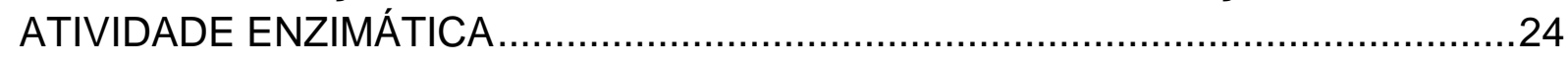

4.1.1 Protocolo Sigma para determinação da atividade enzimática ..........................24

4.1.2 Protocolo Imada para determinação da atividade enzimática .........................25

4.1.3 Protocolo Microplaca para determinação da atividade enzimática ....................26

4.1.4 Preparo dos reagentes e soluções utilizadas .............................................26

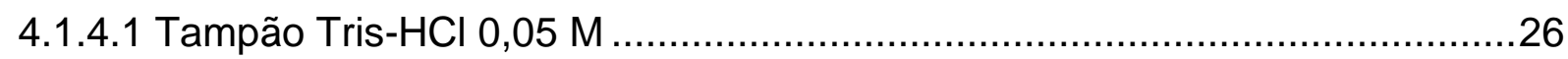

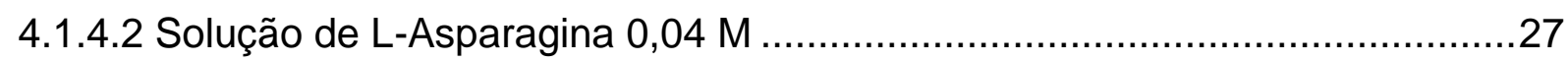

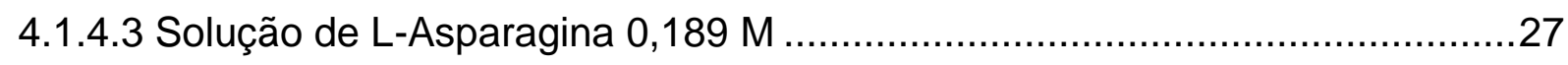

4.1.4.4 Solução de ácido tricloroacético (TCA) 1,5M ........................................27

4.1.5 Processo de ultrafiltração ......................................................................2

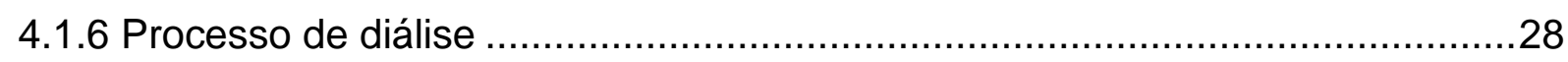

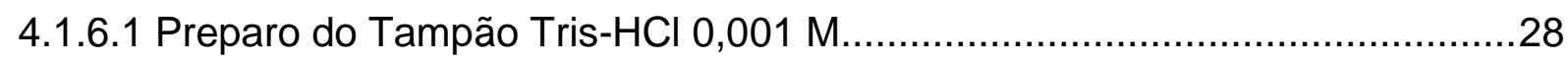

4.1.7 Avaliação de diferentes condições de centrifugação da amostra ......................28

4.1.8 Avaliação de diferentes tempos de incubação durante a reação de

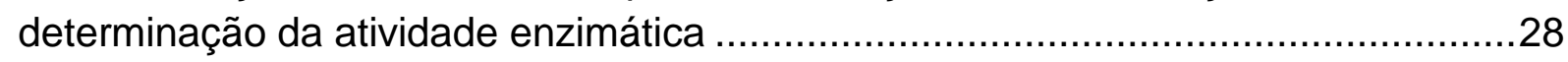

4.1.9 Avaliaçao de diferentes concentrações de substrato na determinação da

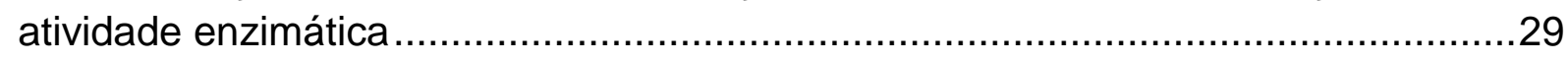

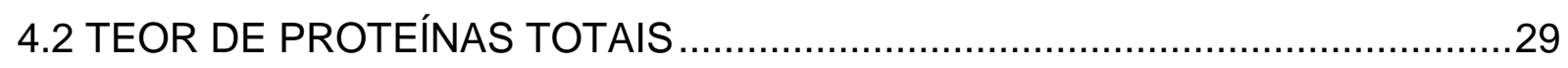

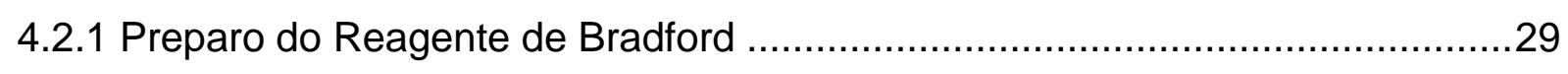

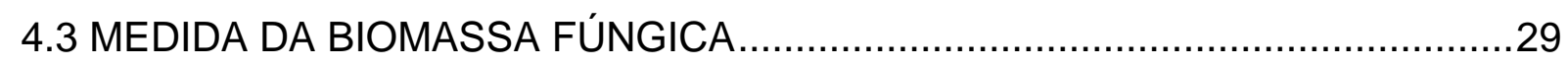

4.4 ISOLAMENTO E IDENTIFICAÇÃO DOS FUNGOS FILAMENTOSOS ................30

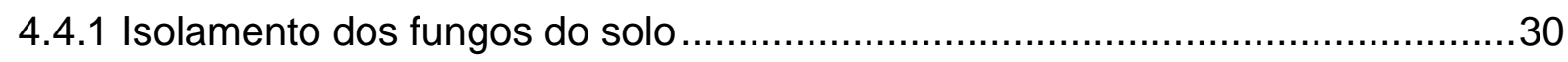


4.4.2 Isolamento dos fungos endofíticos .31

4.5 PREPARAÇÃO DO INÓCULO.

4.6 SELEÇÃO DE FUNGOS QUANTO À PRODUÇÃO DE L-ASPARAGINASE EM MEIO SÓLIDO. 32

4.7 SELEÇÃO DE FUNGOS QUANTO À PRODUÇÃO DE L-ASPARAGINASE EM

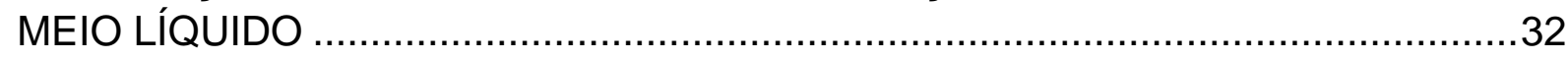

4.8 PRESERVAÇÃO DOS FUNGOS PRODUTORES DE L-ASPARAGINASE.........33

4.9 AVALIAÇÃO DA MELHOR CONDIÇÃO DE CULTIVO PARA A PRODUÇÃO

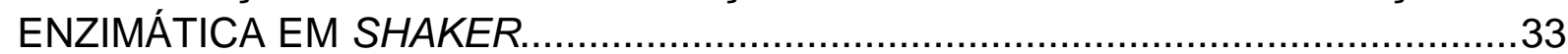

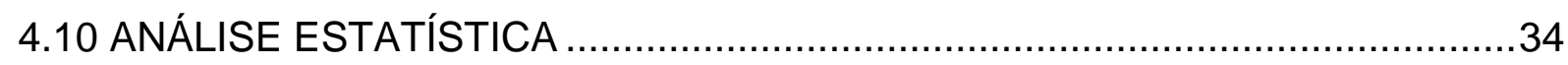

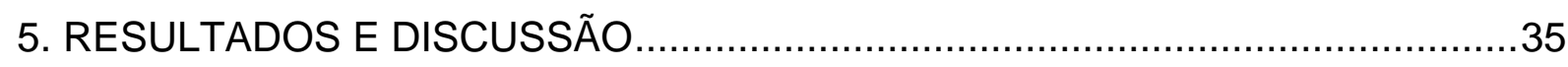

5.1 PADRONIZAÇÃO DA METODOLOGIA DE DETERMINAÇÃO DA ATIVIDADE

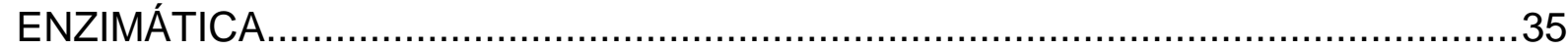

5.2 PADRONIZAÇÃO DO PROCESSO DE PRODUÇÃO DE L-ASPARAGINASE EM

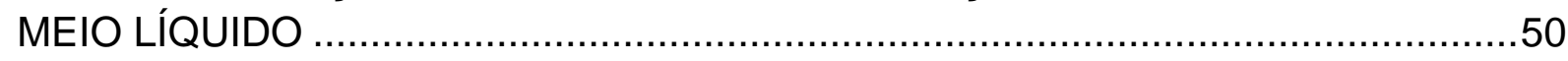

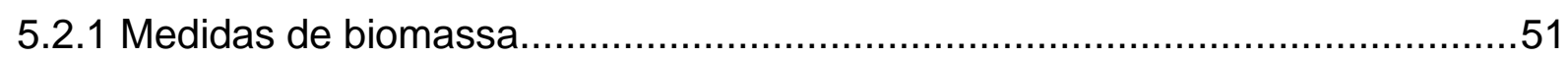

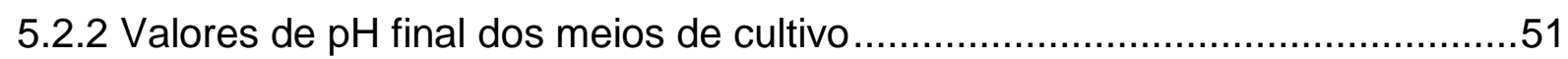

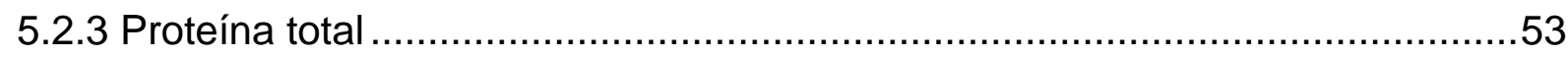

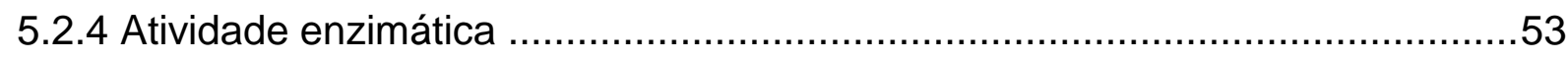

5.3 ISOLAMENTO E IDENTIFICAÇÃO DOS FUNGOS FILAMENTOSOS ................55

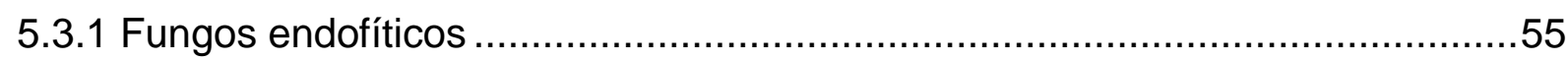

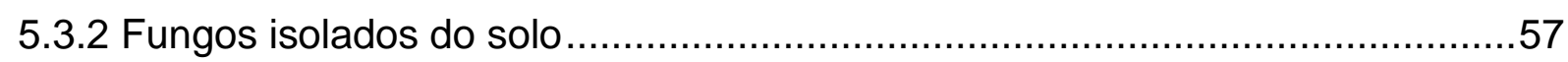

5.4 SELEÇÃO DE FUNGOS QUANTO À PRODUÇÃO DE L-ASPARAGINASE EM

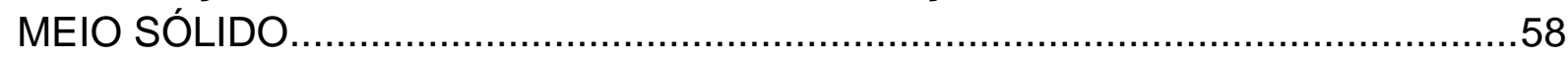

5.5 SELEÇÃO DE FUNGOS QUANTO À PRODUÇÃO DE L-ASPARAGINASE EM

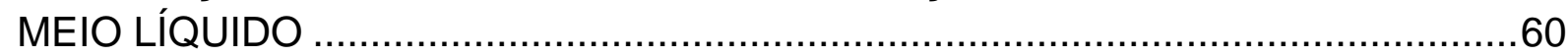

5.6 MELHORAMENTO DA PRODUÇÃO DE L-ASPARAGINASE EM SHAKER ......63

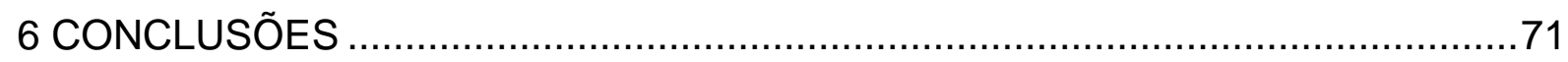

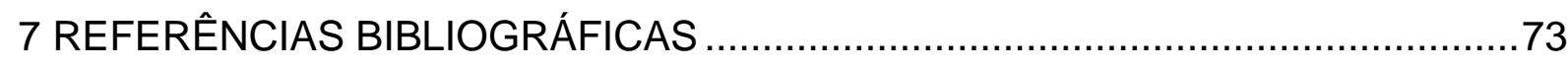




\section{INTRODUÇÃO}

A leucemia linfóide aguda (LLA) é uma neoplasia maligna de linfócitos, caracterizada pelo acúmulo de células imaturas na medula óssea, sangue periférico e órgãos linfóides (NEHMY et al., 2011). A LLA é o tipo mais comum de leucemia na infância, apresentando um pico de incidência entre o segundo e o quinto anos de vida, regredindo nas faixas etárias maiores. Ocorre ainda uma variação de gênero e etnia, indicando maior incidência em crianças do sexo masculino, em relação às do sexo feminino, além de acometer, mais frequentemente, crianças caucasianas (PUI, C. H.; RELLING;DOWNING, 2004; ADELMAN et al., 2007; BELSON; KINGSLEY;HOLMES, 2007; ONCIU, 2009).

O evento patogênico que leva ao desenvolvimento dessa patologia ainda é desconhecido, entretanto, é improvável que seja resultado de apenas um único evento. As interações entre possíveis alterações genéticas, fatores ambientais e infecciosos parecem ser a causa mais provável para o surgimento da LLA (GREAVES;WIEMELS, 2003; KEBRIAEI; ANASTAS;LARSON, 2003). A sintomatologia da doença é muito variável, dependendo de alterações das séries vermelhas, branca e megacariocítica. A ocorrência de palidez, apatia, taquicardia, febre e infecções recorrentes são frequentes. Além disso, o paciente pode apresentar episódios hemorrágicos e sintomas associados ao acometimento do sistema nervoso central (KEBRIAEI; ANASTAS;LARSON, 2003; PUI, CH ;THIEL, 2009).

O tratamento da LLA preconiza a combinação de drogas com diferentes mecanismos de ação, resultando, atualmente, em altos índices de sobrevida. De maneira geral, o tratamento de crianças com LLA segue três fases terapêuticas principais: indução, consolidação e manutenção (PUI, C. H.;EVANS, 2006). Dentro dessas fases, uma enzima é de suma importância para o sucesso da terapia, a LAsparaginase, que é utilizada durante o tratamento e também na indução da remissão da doença, em protocolos pediátricos e adultos (PIETERS et al., 2011).

As enzimas são proteínas biocatalisadoras de um enorme repertório de reações químicas, sendo essenciais para a quebra de moléculas relacionadas com o crescimento e, consequentemente, com a vida de todos os organismos (HOLLIDAY; MITCHELL;THORNTON, 2009; ZIMMER et al., 2009). Além disso, possuem papel 
fundamental na degradação da matéria orgânica, na infecção do hospedeiro e na deterioração dos alimentos. Visto que são moléculas que apresentam alta especificidade e seletividade de atuação sobre substratos, as enzimas vêm sendo muito utilizadas nos setores biotecnológicos e em processos industriais nas áreas de segmento têxtil, produção de fármacos, cosméticos, alimentos e bebidas, apresentando assim, grande participação no comércio mundial (ORLANDELLI et al., 2012).

O mercado mundial de enzimas está dividido em dois setores: o das enzimas industriais, que correspondem a $60 \%$ do mercado industrial e aquele das enzimas especiais, tais como, as enzimas terapêuticas e aquelas destinadas para diagnósticos e pesquisas. A grande eficiência das enzimas, aliada à sua alta especificidade, tornam-nas agentes de grande potencial para uso terapêutico (ZIMMER et al., 2009). A L-Asparaginase é uma dessas enzimas e atua na hidrólise do aminoácido asparagina, gerando ácido aspártico e amônia e, por isso, é uma das drogas mais utilizadas no tratamento da LLA (NOMME et al., 2012; MOHAN KUMAR;MANONMANI, 2013). A L-Asparaginase é um produto natural importante que possui um amplo espectro de atividade antitumoral. Além da leucemia linfóide, a enzima tem sido aplicada no tratamento de muitas outras doenças, como a doença de Hodgkin's, leucemia mielocítica aguda, leucemia mielomonocítica aguda, leucemia linfocítica crônica, linfossarcoma, reticulossarcoma e melanossarcoma (DUVAL et al., 2002; WINK, 2009; KAVITHA;VIJAYALAKSHMI, 2012).

A existência de vários micro-organismos produtores de L-Asparaginase é uma grande vantagem para a obtenção de enzimas que possam ser utilizadas clinicamente. Esses micro-organismos representam alternativa atraente, uma vez que podem ser cultivados em grandes quantidades e em um período de tempo relativamente curto (SARQUIS et al., 2004). Existem três formas da L-Asparaginase utilizadas atualmente na clínica, entretanto, todas são de origem bacteriana e podem causar indução da resposta imune, produzindo anticorpos anti-asparaginase e, consequentemente, reduzindo sua ação terapêutica (SARQUIS et al., 2004; RIZZARI et al., 2013).

Diante dessa problemática, uma alternativa promissora para o desenvolvimento de um produto com menos efeitos adversos, é a utilização de micro-organismos eucariotos. Algumas leveduras e fungos filamentosos já foram citados como potenciais produtores de L-Asparaginase. Gêneros como Aspergillus, 
Penicillium e Fusarium são, frequentemente, relatados na literatura científica como produtores da enzima (PALLEM; NAGARJUN;SRIKANTH, 2011; KUMAR et al., 2013; NIHARIKA YADAV;SARKAR, 2014; IMADA et al., 1973; SARQUIS et al., 2004).

Nos dias atuais, há um movimento mundial no sentido de prospectar novos meios de produção de princípios ativos farmacêuticos obtidos por processos biotecnológicos. O Brasil, no entanto, não acompanha essa tendência, revelando reduzida participação em pesquisa e produção industrial farmacêutica em relação ao cenário mundial. Além disso, fornecedores internacionais de biofármacos para o país estão perdendo o interesse no mercado e descontinuando a produção de diversos desses, principalmente os relacionados ao tratamento onco-hematológico, o que agrava ainda mais essa situação (ABIFINA; WINK, 2009).

Assim, revela-se importante o estudo de novos micro-organismos capazes de produzir L-Asparaginase extracelularmente, com potencial aplicação farmacêutica. Neste contexto, encaixa-se o estudo de fungos filamentosos presentes no solo e em espécies vegetais do bioma Cerrado brasileiro, localizado na região Centro-Oeste, levando em consideração características como a baixa umidade do solo desta região e as altas temperaturas, presentes durante a maior parte do ano. 


\section{REVISÃO BIBLIOGRÁFICA}

\subsection{LEUCEMIAS}

As leucemias constituem um grupo de doenças neoplásicas provenientes da expansão clonal de células imaturas (blastos) que darão origem as células sanguíneas na medula óssea. As células-tronco hematopoiéticas possuem a capacidade de se diferenciarem, primeiramente, em dois tipos celulares, a linhagem linfóide e a linhagem mielóide (SCHOCH et al., 2001). Na leucemia, essas células progenitoras são incapazes de se diferenciar em células maduras, impedindo a formação de células sanguíneas normais e levando ao acúmulo das mesmas na medula óssea e no sangue periférico (CIMINO et al., 1993; GREAVES;WIEMELS, 2003).

A classificação das leucemias se dá a partir de dois fatores principais, a depender do precursor celular que sofreu malignização e pela rapidez do desenvolvimento e progressão da doença (FOON;TODD, 1986; WANG;DICK, 2005). No primeiro caso, a doença ocorre devido à modificação do progenitor celular, este que pode ser da linhagem linfóide ou mielóide. A classificação correta das leucemias é fundamental para aplicação da terapêutica adequada e pode ser realizada a partir de técnicas morfológicas, citoquímicas e imunofenotípicas (DIGIUSEPPE, 2007). Em alguns pacientes, não se revela uma linhagem bem definida durante o diagnóstico, apresentando antígenos das linhagens mielóide e linfóide. Nestes casos, diferentes denominações para a doença podem ser utilizadas, como leucemia de células mistas, leucemia híbrida ou leucemia bifenotípica (MORAVEJl et al., 2014; YUE et al., 2015).

As leucemias podem ser classificadas ainda, conforme a fisiopatologia da doença, em agudas e crônicas. Na forma aguda da leucemia, células imaturas estão presentes no sangue e na medula óssea, como consequência da perda da capacidade de maturação por parte das células que originam o clone neoplásico (HARRIS et al., 1999; PUI, CH; CAMPANA;EVANS, 2001; NEHMY et al., 2011). Possui um curso clínico mais rápido e, se não tratada rapidamente, leva ao óbito em poucas semanas ou meses. Enquanto que, na forma crônica da doença, as células malignas se desenvolvem em estágios de maturação mais tardios e, 
consequentemente, caracteriza-se pela hiperplasia maciça desses elementos maduros (KERSEY, 1997). As leucemias crônicas possuem progressão mais lenta, com história natural chegando a durar até alguns anos (WANG;DICK, 2005).

Embora de rara incidência global, a leucemia é o tipo mais comum de câncer infantil. A neoplasia é responsável por cerca de $30 \%$ de todos os cânceres diagnosticados em crianças menores de 15 anos. Dentro dessa população, a LLA é cerca de cinco vezes mais frequente do que leucemia mielóide aguda (LMA) e representa cerca de $75 \%$ de todos os diagnósticos de leucemia na infância (BELSON; KINGSLEY;HOLMES, 2007; ONCIU, 2009). No Brasil, as leucemias agudas são as neoplasias mais frequentes na infância, variando de 15 a 45\% de todas as doenças malignas diagnosticadas nesta faixa etária (CAMARGO et al., 2010), enquanto que as leucemias crônicas são mais raras (CHEOK; LUGTHART;EVANS, 2006).

\subsubsection{Leucemia Linfóide Aguda}

A LLA é uma neoplasia maligna de linfócitos, caracterizada pelo acúmulo de células sanguíneas imaturas da medula óssea. O mecanismo que leva ao desenvolvimento dessa patologia ainda é desconhecido, entretanto, é improvável que seja resultado de um único evento (KEBRIAEI; ANASTAS;LARSON, 2003). Sabe-se que alterações nos genes que controlam a homeostase da célula linfóide são responsáveis pela expansão clonal desregulada de células progenitoras imaturas, originando células leucêmicas chamadas de linfoblastos (BEKKERMÉNDEZ et al., 2014; PAN et al., 2014; HAGAG;NOSAIR, 2015)

Apesar da alteração genética ser um fator importante no desenvolvimento da LLA, acredita-se que o acúmulo de vários outros processos envolvendo interações complexas entre a susceptibilidade do hospedeiro, sucessivas alterações cromossômicas e, possivelmente, a incorporação de informações genéticas virais transmitidas às células progenitoras susceptíveis possam estar envolvidos na leucemogênese (GREAVES;WIEMELS, 2003; KEBRIAEI; ANASTAS;LARSON, 2003; CANALLE et al., 2004; BELSON; KINGSLEY;HOLMES, 2007). Anormalidades genéticas hereditárias, tais como Síndrome de Down e Ataxia-telangectasia, além de alguns polimorfismos do gene MTHFR, relacionados ao metabolismo do folato, 
parecem predispor a LLA (KEBRIAEI; ANASTAS;LARSON, 2003; ZANROSSO et al., 2006; LEITE et al., 2007).

Alguns fatores de risco ambientais também parecem estar associados a uma maior susceptibilidade à LLA. Vários estudos têm contribuído para a teoria de que algum agente transmissível possa estar envolvido no processo oncogênico da leucemia na infância. Isso por que o pico de incidência de leucemia infantil, assim como da ocorrência de infecções, ocorre entre crianças de dois a cinco anos de idade, quando o sistema imunológico ainda não é tão desenvolvido (BELSON; KINGSLEY;HOLMES, 2007).

Diferentes agentes infecciosos, a exemplo dos vírus Epstein Barr e HTLV-I A, foram e estão sendo estudados como possíveis fatores associados ao desenvolvimento da LLA em crianças, porém nenhum foi comprovado até 0 momento (GREAVES;WIEMELS, 2003; MCNALLY;EDEN, 2004).

A radiação ionizante é um dos fatores ambientais relacionados à ocorrência de leucemia, principalmente quando a exposição ocorre durante a vida intra-uterina ou durante a primeira infância. A magnitude do risco depende de alguns fatores como a dose de radiação recebida, duração dessa exposição e a idade do indivíduo (NOSHCHENKO et al., 2001; BELSON; KINGSLEY;HOLMES, 2007). Alguns produtos químicos também parecem estar relacionados com a leucemia infantil, como hidrocarbonetos e pesticidas. O hidrocarboneto mais amplamente conhecido é o benzeno e, em estudo realizado por Glass e colaboradores (2003), um excesso de risco de leucemia foi associado com à exposição a este hidrocarboneto (GLASS et al., 2003). Alguns estudos têm sugerido uma ligação entre a exposição a pesticidas e ocorrência de leucemias na infância, no entanto, a maioria destes estudos são limitados devido às informações inespecíficas de exposição e ao pequeno número de crianças expostas (DANIELS; OLSHAN;SAVITZ, 1997; MENEGAUX et al., 2006; BELSON; KINGSLEY;HOLMES, 2007).

A sintomatologia da doença é bastante variável e está relacionada com os graus de anemia, neutropenia e trombocitopenia, alterações laboratoriais comuns dos pacientes com LLA, além da presença de infiltração leucêmica extra-medular (KEBRIAEI; ANASTAS;LARSON, 2003; LEITE et al., 2007). Os principais sinais e sintomas da LLA são atribuídos à substituição das células hematopoiéticas normais pelas células leucêmicas (blastos), assim como pelo crescimento descontrolado 
destas células no tecido linfóide e em sítios extramedulares (ONCIU, 2009; NEHMY et al., 2011).

Os sintomas mais frequentes estão correlacionados à anemia apresentada pelo paciente, como astenia, mal-estar, redução da tolerância ao exercício e palidez. Em seguida, aparecem os sinais e sintomas relacionados à presença de trombocitopenia, sendo petéquias, equimoses, epistaxe e sangramento nas fezes ou na urina (KEBRIAEI; ANASTAS;LARSON, 2003; PUI, CH ;THIEL, 2009). Outras manifestações clínicas da LLA são secundárias à proliferação de blastos e aparecem devido a infiltração destes em diferentes tecidos do organismo como as amígdalas, linfonodos, pele, baço, rins e outros (NEHMY et al., 2011). Episódios de febre, perda de peso, suores noturnos e envolvimento do sistema nervoso central também são frequentes, além dos relatos de dor nos membros, atribuídos a concentração dos clones leucêmicos no interior da medula óssea (KEBRIAEl; ANASTAS;LARSON, 2003). Diversas outras doenças de menor gravidade podem apresentar manifestações semelhantes e, assim, um diagnóstico rápido e preciso é fundamental (NEHMY et al., 2011).

Além da presença dos sinais e sintomas citados no parágrafo anterior, que levam a suspeita do diagnóstico de leucemia, a realização de um hemograma é importante pois fornece informações que podem reforçar essa suspeita, como a observação de anemia, plaquetopenia, leucopenia ou leucocitose e presença de blastos (NEHMY et al., 2011). Entretanto, a confirmação do diagnóstico se dará apenas após a realização do mielograma, com a análise morfológica complementada pelos exames de imunofenotipagem, citogenética e biologia molecular, estes últimos fundamentais para a escolha do esquema terapêutico (CIUDAD et al., 1998; BOROWITZ et al., 2005; DIGIUSEPPE, 2007; COUSTANSMITH et al., 2011).

A LLA é uma neoplasia hematopoiética que apresenta maior incidência na faixa etária pediátrica ou seja, em menores de 15 anos, com pico entre dois e cinco anos de idade, constituindo cerca de um terço de todas as neoplasias malignas da criança. Acomete mais frequentemente o sexo masculino, além de ocorrer uma variação étnica indicando maior incidência em crianças brancas em relação às crianças negras. A LLA apresenta ainda, maior incidência em portadores de outras afecções, como distúrbios genéticos ou com síndromes de imunodeficiência (PUI, C. 
H.; RELLING;DOWNING, 2004; CHEOK; LUGTHART;EVANS, 2006; ADELMAN et al., 2007; LEITE et al., 2007; ONCIU, 2009).

Há algumas décadas, as leucemias agudas eram praticamente incuráveis, enquanto hoje, as taxas de cura giram em torno de $80 \%$ para LLA e $45 \%$ para LMA (CHEOK; LUGTHART;EVANS, 2006). A partir da década de 1940, uma sequência de descobertas marcantes contribuiu de forma decisiva para a melhor evolução e sobrevida das pacientes como a descoberta da quimioterapia, utilização de quimioterapia combinada, de manutenção, além dos tratamentos adaptados a grupos de riscos (PUI, C. H.; RELLING;DOWNING, 2004; PUI, C. H.;EVANS, 2006).

Os avanços na remissão e sobrevida dos pacientes estão relacionados a diagnósticos mais precisos e constantes aperfeiçoamentos em protocolos terapêuticos. O tratamento da LLA melhorou muito ao longo dos últimos anos, devido ao desenvolvimento de novos medicamentos e protocolos terapêuticos bem desenhados e estabelecidos. Esse progresso pode ser representado a partir do aumento das taxas de sobrevida em pacientes infantis que, em 1960, era de $10 \%$ e nos dias atuais, gira em torno de 75 a 80\% (CHEOK;EVANS, 2006; PUI, C. H.;EVANS, 2006; LEITE et al., 2007; HENZE, 2008; PIETERS et al., 2011).

O regime de tratamento da LLA utilizado atualmente preconiza a combinação de drogas com diferentes mecanismos de ação e se divide em três fases importantes: indução, consolidação e manutenção. A fase da indução, que busca o retorno à hematopoiese normal, tem por objetivo levar os pacientes à remissão da doença. É realizada através da utilização de uma combinação de quatro agentes antineoplásicos, entre eles, a L-Asparaginase. A duração dessa fase inicial do tratamento é de, aproximadamente, quatro semanas e as taxas de remissão atingidas giram em torno de noventa e cinco por cento (PUI, C. H.;EVANS, 2006; ANDRADE; BORGES;SILVEIRA, 2014; QUINTANILLA-FLORES et al., 2014).

Posteriormente, durante a segunda fase de tratamento, a busca por manter a remissão, além de prevenir infiltrações no Sistema Nervoso Central (SNC), são os principais objetivos a serem alcançados. Esta fase tem duração que pode variar de 2 a 8 meses de tratamento e ocorre a administração de altas doses de metrotexato. $\mathrm{Na}$ terceira fase do tratamento, a terapia de manutenção é realizada. Com duração de, pelo menos, dois anos para o devido controle da doença, faz-se a utilização de doses baixas de metrotexato combinado, na grande maioria dos esquemas, com mercaptopurina (JEHA;PUI, 2009). 
O transplante com células hematopoiéticas pode ser realizado naqueles pacientes que não respondem bem ao tratamento quimioterápico. Esse procedimento consiste em um transplante de células extraídas da medula óssea, do sangue periférico ou do cordão umbilical de um doador compatível (JEHA;PUI, 2009).

Um dos maiores desafios durante o tratamento de neoplasias malignas está relacionado com o fato de que a dose da quimioterapia necessária para destruir as células malignas, muitas vezes têm toxicidade alta para as células normais. Este fato acarreta no aumento da procura de tratamentos mais específicos. Sabe-se que algumas linhagens de células tumorais não são capazes de produzir aminoácidos, dependendo daqueles presente no plasma para a síntese proteica. Esta é a base de uma modalidade de tratamento antitumoral considerada mais seletiva, que consiste na redução dos níveis plasmáticos de aminoácidos, para induzir a apoptose de células tumorais, com menor comprometimento das células saudáveis (FERNANDEZ et al., 2013; GUILLEME et al., 2013).

Dentro deste grupo, a enzima L-Asparaginase é capaz de transformar o aminoácido L-Asparagina em ácido aspártico (SHRIVASTAVA et al., 2015). As células tumorais, mais especificamente os linfócitos, requerem uma enorme quantidade de asparagina para acompanhar seu rápido crescimento. Isto significa que estas células neoplásicas necessitam usar, além daquela que é sintetizada pela própria célula (que é limitada), também a Asparagina presente no soro sanguíneo (proveniente da dieta) para satisfazer sua grande demanda (NARTA; KANWAR;AZMI, 2007). O esgotamento extracelular de L-Asparagina, ocasionado pela ação da L-Asparaginase, inibe a síntese proteica em linfoblastos e induz à apoptose da população de células neoplásicas (FERNANDEZ et al., 2013; GUILLEME et al., 2013).

Entre as drogas indicadas para o tratamento da LLA, a enzima LAsparaginase é uma das mais utilizadas (LOUREIRO, 2010; PIETERS et al., 2011; SAISON et al., 2014). Atualmente, existem três formas da enzima terapeuticamente utilizadas, todas obtidas a partir de cepas bacterianas. Porém, embora este citostático tenha sido uma das maiores contribuições para o tratamento da LLA nos últimos anos, seu uso é ainda limitado devido aos importantes efeitos colaterais (GUILLEME et al., 2013; TONG et al., 2014; NARTA; KANWAR;AZMI, 2007), além 
de que sua formulação e dosagem ideais continuam sendo muito discutidas (PIETERS et al., 2011).

\subsection{ASPARAGINASE}

A L-Asparaginase (L-Asparagina amino hidrolase) é a enzima responsável pela catálise da reação de hidrólise do aminoácido L-Asparagina, resultando em ácido aspártico e amônia, conforme esquematizado na Figura 1 (GURUNATHAN;SAHADEVAN, 2012; NOMME et al., 2012). Detalhando essa reação, a enzima catalisa a hidrólise do nitrogênio do grupo amida da cadeia lateral do aminoácido, convertendo-o em ácido (LOUREIRO, 2010).

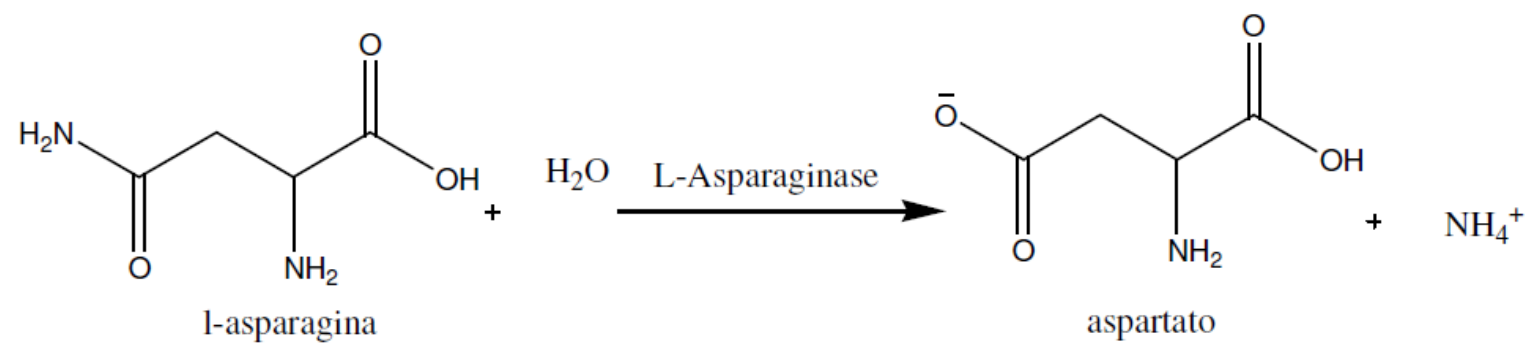

Figura 1 - Reação catalisada pela enzima L-Asparaginase (NARTA; KANWAR;AZMI, 2007).

A reação enzimática de hidrólise realizada pela L-Asparaginase exaure rapidamente os níveis celulares de asparagina presentes no corpo. Diante do fato de que algumas células tumorais são incapazes de garantir seu próprio fornecimento de asparagina, a resposta ao tratamento com a L-Asparaginase é positiva, visto que as células dependem de uma oferta extracelular do aminoácido (MULLER;BOSS, 1998; BUSHMAN et al., 2000; DHALE;MOHAN-KUMARI, 2014). A deficiência de asparagina interfere na síntese de proteínas, ocasionando inibição na produção de DNA e RNA, com consequente deterioração da função celular e apoptose da população de células neoplásicas (GRAHAM, 2003; FERNANDEZ et al., 2013; GUILLEME et al., 2013).

A descoberta e desenvolvimento de Asparaginase como uma droga antineoplásica teve início em 1922, quando Clementi, durante pesquisas utilizando soro de mamíferos, observou que o soro de porquinhos-da-índia apresentava atividade da enzima (NARTA; KANWAR;AZMI, 2007). Anos mais tarde, Kidd (1953) 
relatou a regressão de linfomas transplantados em camundongos pela administração do soro dessas cobaias (KIDD, 1953) e, ao mesmo tempo, várias outras observações foram feitas. Entre essas observações, pode-se destacar o fato de que a inibição do crescimento celular ocorreu apenas a partir da utilização do soro de porquinhos-da-índia, sendo que soros obtidos a partir de outras espécies animais não apresentaram este efeito e, além disso, apenas certos tipos de tumores foram suscetíveis ao mesmo (EL-NAGAR; EL-EWASY;EL-SHWEIHY, 2014).

Broome (1961), após correlacionar os resultados de Kidd e de Clementi, percebeu que a regressão dos linfomas transplantados em camundongos ocorreu devido à dependência nutricional das células malignas em asparagina exógena e, assim, chegou à conclusão de que a atividade antitumoral era consequência da atividade enzimática da L-Asparaginase (EL-NAGAR; EL-EWASY;EL-SHWEIHY, 2014; BROOME, 1961). Investigações posteriores realizadas pelo mesmo autor confirmaram o potencial terapêutico da enzima (BROMME, 1963a, 1963b). Em 1966, um estudo realizado por Yellin e Wriston obteve a purificação parcial de duas isoformas da L-Asparaginase a partir do soro de porquinhos-da-índia, entretanto, apenas uma isoforma exibiu atividade anti-tumoral in vivo (YELLIN;WRISTON JR, 1966).

Devido ao fato de que a extração da L-Asparaginase a partir do soro das cobaias era difícil e a quantidade extraída era insuficiente, a continuidade das pesquisas tornou-se cada vez mais restrita. Assim, os pesquisadores iniciaram investigações voltadas para a busca de outras fontes enzimáticas, especialmente de origem microbiana (LOUREIRO, 2010; NARTA; KANWAR;AZMI, 2007). Trabalhos publicados por Mashburn e Wriston (1964) e por Campbell e Mashburn, cinco anos mais tarde, relataram a purificação da enzima L-Asparaginase a partir de cepas de Escherichia coli e, além disso, demonstraram que sua atividade anti-tumoral foi semelhante àquela encontrada no soro dos porquinhos-da-índia. Esses resultados foram importantíssimos e deram início à produção enzimática em escalas maiores, possibilitando a obtenção de quantidades adequadas para a realização de ensaios clínicos (ASSELIN et al., 1993; NARTA; KANWAR;AZMI, 2007). 


\subsubsection{Farmacologia e toxicologia}

A síntese de proteínas, nas células humanas, necessita de um suprimento regular do aminoácido Asparagina. Visto que a obtenção desse aminoácido se dá a partir da utilização da enzima asparagina sintetase, a maioria das células humanas podem produzir seus próprios suprimentos de L-Asparagina, não necessitando obtêlos da dieta (MULLER;BOSS, 1998). Entretanto, diferentemente das células normais, as células de alguns tipos de tumores possuem poucos níveis de asparagina sintetase e não conseguem regular positivamente o gene desta enzima durante as condições de depleção de asparagina, sintetizando este aminoácido lentamente (MOOLA et al., 1994; WINK, 2009).

Algumas células neoplásicas requerem, ainda, grandes quantidades de LAsparagina para seu rápido crescimento e, a fim de satisfazer essa demanda, o aminoácido é obtido do meio extracelular. Haja visto que, ao ser injetada ou chegar à corrente sanguínea, a enzima L-Asparaginase ocasiona a depleção das reservas de L-Asparagina presentes no plasma, as células tumorais serão impedidas de obter o aminoácido extracelular, o que, consequentemente, leva à destruição das células tumorais por tornarem-se incapazes de completar a síntese protéica e, assim, sintetizar suas próprias proteínas (TALLURI et al., 2014; NARTA; KANWAR;AZMI, 2007).

A L-Asparaginase é um bioproduto muito importante pois possui um amplo espectro de atividade antitumoral. O seu mecanismo antileucêmico conta com a conversão da L-Asparagina em aspartato a partir da hidrólise do aminoácido (MOOLA et al., 1994; RICHARDS;KILBERG, 2006). Tem sido amplamente utilizada no tratamento de diferentes neoplasias além da LLA, como a doença de Hodgkin's, a LMA, leucemia mielomonocítica aguda, leucemia linfocítica crônica, linfossarcoma, reticulossarcoma e melanossarcoma (DUVAL et al., 2002; WINK, 2009; KAVITHA;VIJAYALAKSHMI, 2012).

Atualmente, três formas de L-Asparaginase estão disponíveis comercialmente: a L-Asparaginase nativa; a L-Asparaginase peguilada (PEGasparaginase), que possui ligação covalente com um grupo polietilenoglicol, ambas obtidas de E. coli; e a L-Asparaginase obtida de Erwinia chrysanthemi (Crisantaspase). Os três tipos possuem o mesmo mecanismo de ação, mas diferem nas suas propriedades farmacocinéticas (WINK, 2009; CORTIJO-CASCAJARES; 
JIMÉNEZ-CEREZO;TEJADA, 2012; KAWEDIA;RYTTING, 2014; RIZZARI et al., 2013). Isso significa que as três formulações não são intercambiáveis na mesma dose e frequência de administração (ASSELIN et al., 1993; PIETERS et al., 2011).

A utilização de terapia parenteral com L-Asparaginase em seres humanos apresenta dois padrões importantes de toxicidade. O primeiro está relacionado a ocorrência de reações de hipersensibilidade, devido ao fato de se introduzir uma proteína estranha ao organismo; já o segundo, apresenta sinais de toxicidade provocados pela inibição de síntese proteica, consequência da diminuição dos níveis de L-Asparagina disponíveis na circulação e também devido à liberação de produtos a partir da hidrólise enzimática (GRAHAM, 2003; LOUREIRO, 2010; RIZZARI et al., 2013).

As reações de hipersensibilidade são os eventos adversos mais frequentes quando se faz a utilização de L-Asparaginase, com uma incidência que pode variar de 6 a 43\%, podendo ocorrer anafilaxia grave em 10\% dos casos (CORTIJOCASCAJARES; JIMÉNEZ-CEREZO;TEJADA, 2012). Kurtzberg e colaboradores (2011) citam ainda que, logo após a administração da enzima derivada de E. coli, a incidência de reações de hipersensibilidade fica em torno de $4 \%$ durante a fase de indução do tratamento, porém, pode chegar a $80 \%$ naqueles pacientes que forem expostos a doses adicionais (KURTZBERG et al., 2011). As reações de hipersensibilidade são acompanhadas da produção de anticorpos anti-LAsparaginase, principal causa de resistência ao medicamento, essa que pode ser sintomática, com sinais de hipersensibilidade clínica, ou assintomática, sem quaisquer sinais (PANOSYAN et al., 2004; PIETERS et al., 2011; TONG et al., 2014; RIZZARI et al., 2013). Ambas resultam na redução da atividade enzimática e, consequentemente, a efetiva depleção de L-Asparagina no plasma não irá ocorrer (AVRAMIS et al., 2002) e, em alguns casos, a atividade enzimática pode ser indetectável (PANOSYAN et al., 2004; KAWEDIA;RYTTING, 2014).

Entre os sintomas que podem aparecer a partir da indução de resposta imune pela L-Asparaginase, incluem-se: urticária, edema, febre, erupções na pele, prurido, hipotensão, bronco espasmos e ocasionalmente choque anafilático (raros casos) (BRUNTON; LAZO;PARKER, 2010; CORTIJO-CASCAJARES; JIMÉNEZCEREZO;TEJADA, 2012; NARTA; KANWAR;AZMI, 2007). Enquanto a urticária pode ser tratada com a utilização de anti-histamínicos, os outros sintomas só desaparecem com a substituição do medicamento ou interrupção do tratamento 
(GRAHAM, 2003). O uso de corticóides e anti-histamínicos, como medidas profiláticas, não é aconselhável, pois podem mascarar os sintomas de inativação da enzima (NARAZAKI et al., 2012). Outros efeitos adversos relatados são: disfunção hepática, alterações na coagulação sanguínea, vômitos, diarréia, pancreatite, supressão da medula óssea, hiperglicemia e baixos níveis séricos de antitrombina III e fibrinogênio (AVRAMIS et al., 2002; PIETERS et al., 2011; NARAZAKI et al., 2012; QUINTANILLA-FLORES et al., 2014).

Naqueles pacientes que, ao utilizarem a L-Asparaginase nativa obtida de $E$. coli, apresentam reações de hipersensibilidade mais graves, a forma peguilada da enzima (conjugada com polietilenoglicol) pode representar uma alternativa mais segura, afinal apresenta imunogenicidade menor (PIETERS et al., 2011; NARTA; KANWAR;AZMI, 2007), além de possuir a vantagem de ter um período de meia-vida biológico maior (ASSELIN et al., 1993; AVRAMIS et al., 2002). Alternativa que pode ser utilizada é aquela obtida de Erwinia (BRUNTON; LAZO;PARKER, 2010; CORTIJO-CASCAJARES; JIMÉNEZ-CEREZO;TEJADA, 2012).

A amônia liberada no sangue a partir da hidrólise da L-Asparagina, catalisada pela L-Asparaginase, parece estar relacionada com a ocorrência de encefalopatia e hepatotoxicidade observadas durante o tratamento (BRUNTON; LAZO;PARKER, 2010; LOUREIRO, 2010). A L-Asparaginase de origem bacteriana pode hidrolisar além de L-Asparagina, o aminoácido glutamina, porém com uma afinidade bem menor (ASSELIN et al., 1993; GRAHAM, 2003; VAN DER SLUIS et al., 2013). Os produtos da hidrólise da glutamina e da L-Asparagina, o glutamato e o aspartato, respectivamente, parecem estar diretamente relacionados com a neurotoxicidade que ocorre em cerca de $25 \%$ dos pacientes que realizam tratamento com a enzima. Os sintomas de neurotoxicidade incluem depressão, fadiga, sonolência, confusão, irritabilidade, agitação, tontura e suas ocorrências são mais frequentes em paciente adultos (LOUREIRO, 2010).

Devido à redução dos níveis séricos da L-Asparagina nos pacientes que fazem uso da L-Asparaginase, vários efeitos adversos podem ocorrer, como a diminuição da síntese proteica em tecidos normais como o fígado e o pâncreas (KURTZBERG et al., 2011; NARTA; KANWAR;AZMI, 2007). No pâncreas, pode ocorrer pancreatite, além da redução da secreção de insulina e de enzimas que atuam na digestão (QUINTANILLA-FLORES et al., 2014). Quanto ao fígado, os efeitos que podem ser observados são a diminuição dos níveis séricos de albumina 
e de lipoproteínas (PIETERS et al., 2011; SAISON et al., 2014; NARTA; KANWAR;AZMI, 2007).

Outro sinal de toxicidade que pode ocorrer está relacionado a anormalidades de coagulação, devido à deficiência de fatores de coagulação. Diante disso, vale ressaltar que os problemas de coagulação podem assumir a forma de trombose espontânea relacionada com a deficiência dos fatores S, C ou de antitrombina III ou, com menor frequência, de episódios hemorrágicos (BRUNTON; LAZO;PARKER, 2010; SHRIVASTAVA et al., 2015).

No Brasil, o uso da L-Asparaginase para a maioria das aplicações clínicas ainda depende da sua importação e, por isso, o preço da droga é extremamente elevado, o que ocasiona uma grande limitação no uso terapêutico por parte dos pacientes (WINK, 2009). Além disso, notícias em meios de divulgação populares e científicos, em meados do ano de 2013, relatam que a produção de L-Asparaginase foi suspensa pelo fabricante estrangeiro que fornece o medicamento para o Brasil, causando assim, a interrupção do fornecimento do medicamento e grande preocupação por parte das sociedades médicas e órgãos do Ministério da Saúde (MS) (SOBOPE, 2013).

\subsection{FUNGOS FILAMENTOSOS PRODUTORES DE ASPARAGINASE}

Fungos filamentosos são organismos metabolicamente ativos e, por isso, são explorados comercialmente como fontes celulares para a produção de uma grande variedade de enzimas e de outros metabólitos. Diversas espécies, fontes de compostos bioativos, são conhecidas e as pesquisas que visam o isolamento desses produtos são muito expressivas em todo o mundo (SUN et al., 2011). Entre os exemplos de origem fúngica estão o antibiótico penicilina, o imunossupressor ciclosporina e 0 agente hipocolesterolemiante lovastatina (BRAKHAGE;SCHROECKH, 2011). Alguns exemplos de fungos filamentosos e sua produção de metabólitos ativos estão apresentados na Tabela 1. 
Tabela 1 - Metabólitos de importância para a Indústria Farmacêutica produzidos por fungos filamentosos.

\begin{tabular}{ccc}
\hline Composto & Fungos filamentosos & Principal aplicação \\
\hline Alcalóides do Ergot & Claviceps purpurea & Tratamento da \\
Cefalosporina & Acremonium chrysogenum & Antibiótico \\
Ciclosporina & Tolypocladium nivenum & Imunossupressor \\
Griseofulvina & Penicillium griseofulvum & Agente antifúngico \\
Lovastatina & Monascus ruber, & Hipocolesterolemiante \\
Penicilina & Aspergillus terreus & \\
\hline Fonte: (BENNETT, 1998; MEYER, 2008).
\end{tabular}

Alguns produtos naturais de origem fúngica tem se mostrado fármacos revolucionários contra diversos processos patológicos e também tem servido como inspiração para fármacos inovadores. Neste contexto, pode-se citar a enzima LAsparaginase que, ao longo das últimas décadas, tem surgido como um excelente agente anti-neoplásico, especialmente utilizado no tratamento da LLA (SINGH;SRIVASTAV, 2013). A enzima pode ser produzida a partir de uma variada gama de organismos vivos, incluindo plantas, animais e micro-organismos. Apesar disso, são as fontes bacterianas as mais utilizadas para a produção desta enzima (MISHRA, 2006; RAMYA et al., 2012).

Atualmente, a L-Asparaginase de origem bacteriana é produzida em escala industrial, disponível comercialmente e utilizada na clínica (CORTIJOCASCAJARES; JIMÉNEZ-CEREZO;TEJADA, 2012; RIZZARI et al., 2013), entretanto, está frequentemente associada à ocorrência de reações adversas (SHRIVASTAVA et al., 2012). Além disso, outro problema envolvido com a enzima bacteriana, é a produção intracelular da mesma. Esse fato torna o processo de extração e purificação da enzima muito difícil e bastante oneroso (MAHAJAN et al., 2013). Diante disso, a busca por outras fontes de L-Asparaginase tem sido alvo de muitas pesquisas, com o objetivo de se obter a produção de enzimas extracelulares 
pelos micro-organismos, com altos rendimentos, além de apresentar menos efeitos adversos (SARQUIS et al., 2004).

Várias espécies de fungos filamentosos são conhecidas por produzir a enzima L-Asparaginase e, entre elas, pode-se destacar as espécies dos gêneros Aspergillus, Penicillium, Fusarium e Cladosporium (NAKAHAMA et al., 1973; SHRIVASTAVA et al., 2012; MOHAN KUMAR;MANONMANI, 2013; PATRO et al., 2014). No entanto, alguns desses gêneros podem produzir micotoxinas, entre as quais destacam-se a aflatoxina, ocratoxina, zearalenona, entre outras. As micotoxinas são metabólitos secundários, de baixo peso molecular, que apresentam efeitos extremamente tóxicos para o homem e outros animais. Os fungos produzem muitos metabólitos e, diante disso, para que uma substância seja caracterizada como micotoxina, ela deve satisfazer alguns critérios como ser causadora de doenças em homens ou animais, ocorrer na natureza, ser produzida por fungo e apresentar toxicidade aguda ou crônica (ESPOSITO;AZEVEDO, 2010; MAZIERO;BERSOT, 2010).

Foram descritas muitas espécies de fungos produtoras de L-Asparaginase, tais como as de Aspergillus acolumnaris, A. alliaceus, A. amstelodami, A. awamori, A. flavus, A. japonicus, A. nidulans, A. niger, A. niveus, A. oryzae, A. penicilliformis, A. puniceus, A. striatus, A. sunderbanii, A. tamarii, A. terreus, A. wentii, Cladosporium sp., Fusarium anguioides, F. caucasicum, $F$. culmorum, $F$. moniliforme, F. oxysporum, F. roseum, F. semitectum, F. solani, F. tricinctum, Penicillium aculeatum, $P$. chrysogenum, $P$. citrinum, $P$. claviforme, $P$. crustosum, $P$. digitatum, $P$. expansum, $P$. granulatum, $P$. nelicum, $P$. nigricans, $P$. urticae and also Tilachlidium humicola e Verticillium malthoasei (SCHEETZ; WHELAN;WRISTON, 1971; NAKAHAMA et al., 1973; GULATI; SAXENA;GUPTA, 1997; RANI; SUNDARAM;VASANTHA, 2012; TIPPANI;SIVADEVUNI, 2012; MOHAN KUMAR;MANONMANI, 2013; IMADA et al., 1973).

Muitos fatores nutricionais e condições de cultivo podem ser utilizados para a produção enzimática a partir de micro-organismos. A produção de L-Asparaginase, por exemplo, é muito influenciada pela composição do meio de cultivo e depende também dos diferentes fatores que envolvem as condições do processo fermentativo como a temperatura do incubador, o $\mathrm{pH}$ do meio de cultivo, o tamanho do inóculo utilizado, a taxa de agitação do processo, além do tempo de incubação (WEI;LIU, 1998; HYMAVATHI et al., 2009; GURUNATHAN;SAHADEVAN, 2012). 
Shrivastava e colaboradores (2012) produziram L-Asparaginase a partir da espécie Penicillium digitatum, utilizando o meio Czapek Dox modificado (CDM) composto por glicose $2 \mathrm{~g} / \mathrm{L}$, L-Asparagina $10 \mathrm{~g} / \mathrm{L}, \mathrm{KH}_{2} \mathrm{PO}_{4} 1,52 \mathrm{~g} / \mathrm{L}, \mathrm{KCl}$ 0,52 g/L, $\mathrm{MgSO}_{4} .7 \mathrm{H} 2 \mathrm{O} 0,52 \mathrm{~g} / \mathrm{L}$, traços de $\mathrm{CuNO}_{3} .3 \mathrm{H} 2 \mathrm{O}, \mathrm{ZnSO}_{4} .7 \mathrm{H} 2 \mathrm{O}, \mathrm{FeSO}_{4} .7 \mathrm{H} 2 \mathrm{O}$ e pH 6,2 (SHRIVASTAVA et al., 2012). Meio de cultura muito semelhante foi utilizado, com resultados positivos, para a produção de L-Asparaginase a partir da espécie Aspergillus terreus. Esses estudos realizaram a otimização da produção enzimática a partir de parâmetros como temperatura, agitação e tempo de incubação, tamanho do inóculo, além da relação $\mathrm{C}: \mathrm{N}$ e do valor de pH na composição do meio de cultivo (GURUNATHAN;SAHADEVAN, 2011, 2012). Sarquis e colaboradores (2004) também utilizaram o meio CDM, variando as fontes de nitrogênio (L-Asparagina, LProlina, uréia e glutamina), para a produção da enzima a partir das espécies $A$. terreus e A. tamarri. (SARQUIS et al., 2004).

Zia e colaboradores (2013) utilizaram subprodutos de resíduos agroindustrias para a produção de L-Asparaginase a partir da espécie A. niger (ZIA et al., 2013). Patro e colaboradores (2014) obtiveram valores positivos de produção de LAsparaginase a partir de uma cepa de A. flavus. Neste trabalho, os autores testaram diferentes condições de cultivo como o tempo de incubação, $\mathrm{pH}$ do meio e diferentes fontes de carbono e nitrogênio (PATRO et al., 2014). Akilandeswari e colaboradores (2012) utilizaram isolados fúngicos de amostras de água para produzir asparaginase e obtiveram resultados positivos a partir de uma cepa de $A$. niger. Além disso, os efeitos do $\mathrm{pH}$ e temperatura foram investigadas na produção enzimática (AKILANDESWARI; KAVITHA;VIJAYALAKSHMI, 2012).

Em estudo realizado por Nakahama e colaboradores (1973), várias espécies de Fusarium foram produtoras de L-Asparaginase e apenas três das cinquenta cepas testadas não produziram a enzima em níveis superiores a $0,1 \mathrm{Ul} / \mathrm{mL}$ (NAKAHAMA et al., 1973). Imada e colaboradores (1973) também obtiveram produção de L-Asparaginase a partir de espécies do gênero Fusarium, assim como do gênero Penicillium (IMADA et al., 1973). Fatores nutricionais relacionados com a produção de L-Asparaginase pelas espécies $F$. semitectum, $F$. oxysporum e $F$. moniliforme foram estudados por Tippani e colaboradores (2012) (TIPPANI;SIVADEVUNI, 2012).

Apesar de a fermentação submersa ser a técnica mais utilizada para a produção de enzimas, fermentações em estado sólido também foram utilizadas para 
produzir L-Asparaginase a partir de fungos filamentosos (ORLANDELLI et al., 2012). Mishra e colaboradores (2006) realizaram um estudo a partir de uma cepa da espécie $A$. niger, onde obtiveram a produção de L-Asparaginase em fermentação em estado sólido, utilizando resíduos agroindustriais. Rani e colaboradores (2012) conseguiram produzir L-Asparaginase a partir de uma espécie de Aspergillus. Foi utilizada a técnica de fermentação em estado sólido usando diferentes substratos. Entre os vinte substratos testados, foi com a casca de laranja que foram obtidos os maiores níveis de produção enzimática (RANI; SUNDARAM;VASANTHA, 2012). Alguns trabalhos tem demonstrado que a utilização de farelo de trigo como substrato em fermentações em estado sólido resulta em valores de produção de LAsparaginase positivos, quando utilizadas as espécies Aspergillus terreus, Fusarium oxysporum e Cladosporium sp (PALLEM; NAGARJUN;SRIKANTH, 2011; MOHAN KUMAR;MANONMANI, 2013; NAIR et al., 2013).

A existência de vários organismos produtores de L-Asparaginase é uma grande vantagem para a obtenção de enzimas que possam ser utilizadas clinicamente, entretanto, alguns pontos são cruciais para a obtenção de um produto final eficaz. Broome (1968) relatou em seu trabalho que, para que esta enzima seja utilizada clinicamente como um medicamento antineoplásico, é necessário que ela seja facilmente isolada, estável e ativa em $\mathrm{pH}$ e temperatura fisiológicos e que apresente um baixo valor de $\mathrm{Km}$, ou seja, uma alta afinidade da enzima pelo substrato (BROOME, 1968). Além disso, a seleção de fungos produtores deve levar em consideração o fato de a espécie não produzir micotoxinas nas condições de cultivo em questão, não ser patogênica ao homem e ser de fácil manipulação genética (RAJASEKARAN; CHANDRASEKARAN;MUTHUSELVAM, 2008).

\subsection{O CERRADO BRASILEIRO}

O modelo vigente de produção e consumo na sociedade moderna ocasionou muitos avanços tecnológicos, bem como modificações no comportamento das pessoas, no meio ambiente e nas relações sócio culturais. No entanto, igualmente, ensejou uma profunda degradação ambiental, afetando a biodiversidade, e, por consequência, a saúde humana. Assim, revela-se de grande importância a 
manutenção da diversidade biológica e a sustentabilidade dos ecossistemas (SILVA, 2013).

A preocupação ambiental decorre do fato de que o modo de produção, fundado no uso desenfreado dos recursos naturais, produziu danos irreparáveis ao meio ambiente, ensejando o reconhecimento da necessidade de uma mudança de paradigma. Assim, faz-se importante dar preponderância aos métodos fundados no desenvolvimento sustentável, de modo a combinar os interesses econômicos com a proteção à natureza (SILVA, 2013).

O Brasil é reconhecido, mundialmente, como um dos países que possui maior riqueza e exuberância natural, com uma ampla diversidade biológica dispersa ao longo dos vários ecossistemas. Estima-se que $10 \%$ de toda a biota terrestre encontra-se no país (MACHADO et al., 2004; SILVA, 2013). Embora, na literatura, sejam encontradas diferentes estimativas de riqueza, a enorme quantidade de espécies encontradas no território brasileiro, além da sua dimensão continental, do isolamento geográfico observado no passado remoto e da grande variação de ecossistemas, são algumas das razões que explicam sua grande importância como fornecedor de bioprodutos industriais e farmacêuticos (MACHADO et al., 2004; FUNARI;FERRO, 2005).

O Cerrado é o segundo maior bioma do Brasil, sendo sua área original superada apenas pela Floresta Amazônica (KLINK;MACHADO, 2005; QUEIROZ, 2009). Possuindo cerca de 203 milhões de hectares, segundo IBGE (2004) o que corresponde a aproximadamente dois milhões de $\mathrm{km}^{2}$ ou $25 \%$ de todo território brasileiro, a região do Cerrado comporta uma extensa dimensão física, compreendendo parte dos Estados de Goiás, Tocantins, Mato Grosso, Mato Grosso do Sul, Bahia, Minas Gerais, São Paulo, Maranhão, Piauí, Paraná e Rondônia, além do Distrito Federal (QUEIROZ, 2009; BRASIL, 2011).

O termo Cerrado é comumente utilizado para designar o conjunto de ecossistemas (savanas, matas, campos e matas de galeria) que ocorrem no Brasil Central. O clima da região é citado como estacional, caracterizado por um período de chuva que ocorre nos meses de outubro a março, seguido um período seco, que compreende os meses de abril a setembro. As temperaturas médias anuais giram em torno de $22^{\circ} \mathrm{C}$ a $27^{\circ} \mathrm{C}$ e a precipitação média anual é de $1.500 \mathrm{~mm}$ (KLINK;MACHADO, 2005). 
A biodiversidade do Cerrado é bastante expressiva e muito associada com a composição vegetal e variação dos ecossistemas (MACHADO et al., 2004; KLINK;MACHADO, 2005). A região abriga, aproximadamente, um terço da biota brasileira e sua riqueza mínima é estimada em 320 mil espécies (FERRO;DINIZ, 2007). Estima-se que existam 7.000 espécies de plantas, 199 de mamíferos, 837 de aves, 150 de anfíbios, 180 de répteis, 1.200 espécies de peixes e cerca de 90 mil espécies de insetos (FERRO;DINIZ, 2007; SIQUEIRA, 2010).

A microbiota fúngica também é bem elevada no bioma Cerrado brasileiro. A riqueza florística da região, com alto nível de endemismo, contribui para a biodiversidade de espécies de fungos encontradas neste bioma. Os fungos do solo são cruciais para a manutenção desse ecossistema, pois desempenham funções essenciais como a decomposição e ciclagem de nutrientes, além das diversas interações com outros organismos (SIQUEIRA, 2010). Fungos endofíticos, aqueles que são caracterizados por colonizar os tecidos das plantas de forma simbiótica, sendo assim responsáveis pela grande quantidade de metabólitos secundários produzidos, também já foram isolados de espécies vegetais características do Cerrado brasileiro (SOUZA et al., 2004; MESQUITA, 2011; CHAPLA; BIASETTO;ARAUJO, 2013).

As crescentes transformações de degradação ocorridas no Cerrado brasileiro, iniciada desde que a capital brasileira foi transferida para a região, ocasionaram um estado de depleção devido aos impactos humanos de proporção sem precedentes, como construções, desmatamento e queimadas descontroladas, além das práticas de agricultura e pecuária, muito realizadas na região (KLINK;MACHADO, 2005; VILELA et al., 2012). A situação de vulnerabilidade deste bioma pode causar graves consequências ambientais como a extinção da biodiversidade, erosão dos solos, poluição de aquíferos, fragmentação de habitat, degradação de ecossistemas, desequilíbrios no ciclo de carbono e modificações climáticas na região (SIQUEIRA, 2010).

Por possuir uma elevada biodiversidade e que, devido à atual situação de degradação e fragmentação, torna-se ameaçada, muitos trabalhos levaram o Cerrado a ser classificado como um hotspot, isto é, como um dos vinte e cinco biomas terrestres (Figura 2) em situação mais crítica em termos de endemismo e ameaça à suas espécies (MITTERMEIER et al., 1998; MEYERS et al., 2000; KLINK;MACHADO, 2005; QUEIROZ, 2009; VILELA et al., 2012). 


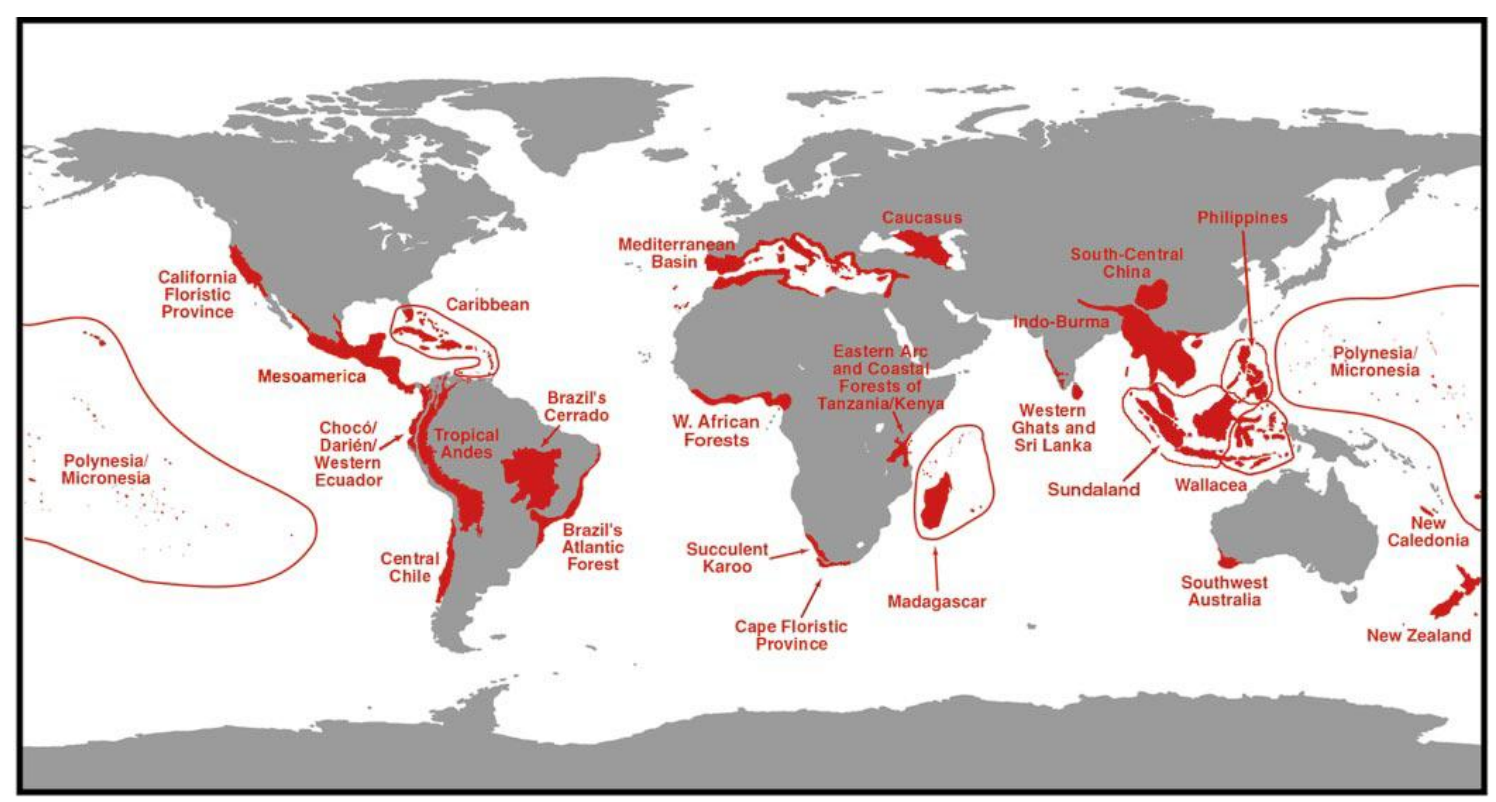

Figura 2 - Os 25 hotspots. As extensões de hotspot compreendem de 3 a $30 \%$ das áreas vermelhas (MEYERS et al., 2000).

Em relatório técnico elaborado no ano de 2010, que utilizou 121 imagens do satélite LANDSAT, datadas de 2009 , os autores concluíram que $48,54 \%$ do bioma Cerrado já havia sido desmatado ou transformado pela ação do homem. No período de 2009-2010, a taxa anual de desmatamento foi de 0,3\%, a maior taxa dentre os seis biomas brasileiros (BRASIL, 2011).

Uma reduzida parcela do bioma Cerrado brasileiro se submete à proteção por meio de sua qualificação como unidades de conservação federais, estaduais e municipais, sendo que essa área representa $7,44 \%$ da área total do bioma. Dessa parcela, 2,91\% se qualifica como unidade de conservação de proteção integral, de que são exemplos os Parques Nacionais (BRASIL, 2011). 


\section{OBJETIVOS}

Este trabalho tem como objetivo avaliar a produção extracelular da enzima LAsparaginase por diferentes espécies de fungos filamentosos isolados do bioma Cerrado, da região Centro-Oeste brasileira.

Para que o objetivo proposto fosse alcançado, os seguintes objetivos específicos foram estabelecidos:

- Padronizar a metodologia para a determinação da atividade enzimática;

- Isolar e identificar fungos filamentosos do solo e endofíticos do bioma Cerrado, da região Centro-Oeste brasileira;

- Identificar, em meio sólido (triagem inicial), os fungos com capacidade de produção de L-Asparaginase;

- Realizar a produção de L-Asparaginase em meio líquido;

- Avaliar a melhor condição de cultivo para a produção de L-Asparaginase em shaker, a partir da variação de alguns parâmetros como pH, concentração de inóculo e relação Carbono:Nitrogênio. 


\section{MATERIAIS E MÉTODOS}

\subsection{PADRONIZAÇÃO DA METODOLOGIA PARA A DETERMINAÇÃO DA ATIVIDADE ENZIMÁTICA}

Para a padronização da metodologia a ser utilizada neste trabalho, três diferentes protocolos foram avaliados e comparados quanto à quantificação da atividade enzimática de L-Asparaginase. Os três métodos utilizam a técnica de Nesslerização e expressam seus resultados em Ul/mL. No entanto, o volume e concentração dos reagentes, tempo de incubação e preparo da amostra são diferentes para cada protocolo. A padronização foi realizada a partir da utilização da enzima L-Asparaginase padrão (Sigma-Aldrich) e também de uma cepa conhecida como produtora de L-Asparaginase: Aspergillus terreus (PC-1.7.A). Foram construídas curvas padrões com diferentes concentrações de sulfato de amônio, para cada uma das metodologias, separadamente.

Uma unidade da atividade de L-asparaginase (UI) foi definida como a quantidade de enzima necessária para formar um $\mu \mathrm{mol}$ de amônia por minuto.

\subsubsection{Protocolo Sigma para determinação da atividade enzimática}

A reação se deu em duas etapas. Na primeira, a mistura da reação foi constituída de $1,0 \mathrm{~mL}$ de tampão Tris- $\mathrm{HCl}(0,05 \mathrm{M}), \mathrm{pH} 8,6 ; 0,9 \mathrm{~mL}$ de água purificada; $0,1 \mathrm{~mL}$ de amostra; e $0,1 \mathrm{~mL}$ de L-Asparagina (189 mM). A mistura foi incubada a $37^{\circ} \mathrm{C}$ por 30 minutos sem agitação e a reação foi interrompida com a adição de $0,1 \mathrm{~mL}$ de ácido tricloroacético (TCA) (1,5 M). Foi preparado o branco da amostra, que se diferencia do tubo teste pela adição da amostra apenas após a adição do TCA. Após os 30 minutos de reação e adição do TCA, todas as amostras foram centrifugadas durante 2 minutos para clarificação.

$\mathrm{Na}$ segunda etapa do teste, a mistura da reação foi constituída por $200 \mu \mathrm{L}$ da mistura resultante da primeira etapa; $4,3 \mathrm{~mL}$ de água purificada e $0,5 \mathrm{~mL}$ do reagente de Nessler (Merck). A reação entre a amônia formada na $1^{\text {a }}$ etapa do teste e o reagente de Nessler produz coloração amarelada, cuja absorbância foi medida em espectrofotômetro a $436 \mathrm{~nm}$. 


$$
U I / m L \text { enzima }=\frac{(\mu \mathrm{mol} \text { de NH3 liberado }) \times(2,2)}{(0,2) \times(30) \times(0,1)}
$$

$2,2=$ volume total da primeira etapa do ensaio $(\mathrm{mL})$.

$0,2=$ volume da primeira etapa $(\mathrm{mL})$ utilizado na segunda etapa do ensaio.

$30=$ tempo do ensaio em minutos.

$0,1=$ volume da amostra $(\mathrm{mL})$ utilizado no ensaio.

\subsubsection{Protocolo Imada para determinação da atividade enzimática}

Neste protocolo, a reação também ocorre em duas etapas. A mistura da primeira etapa da reação contém $0,1 \mathrm{~mL}$ de tampão Tris- $\mathrm{HCl}(0,05 \mathrm{M}), \mathrm{pH} 7,2$; $0,1 \mathrm{~mL}$ de água purificada; $0,2 \mathrm{~mL}$ de L-Asparagina $(0,04 \mathrm{M})$ e $0,1 \mathrm{~mL}$ de amostra. $\mathrm{A}$ incubação foi realizada a $37^{\circ} \mathrm{C}$ durante $60 \mathrm{~min}$. A reação foi interrompida pela adição de $0,1 \mathrm{~mL}$ de TCA $(1,5 \mathrm{M})$. Foram preparados tubos para o branco da amostra e o branco do substrato. No branco da amostra, o conteúdo de substrato foi substituído por tampão Tris-HCl 0,05 M. Já para o branco do substrato, a quantidade de $0,1 \mathrm{~mL}$ de amostra que foi trocada por tampão Tris-HCl.

Para a segunda etapa do teste foram adicionados, em um novo tubo, $0,75 \mathrm{~mL}$ de água purificada, $0,1 \mathrm{~mL}$ da mistura obtida na primeira etapa e $0,15 \mathrm{~mL}$ de reagente de Nessler (Merck). Depois de manter essa mistura a $20{ }^{\circ} \mathrm{C}$ durante 20 minutos, a absorbância foi medida a $450 \mathrm{~nm}$, em espectrofotômetro.

$$
U I / m L \text { enzima }=\frac{(\mu \mathrm{mol} \text { de NH3 liberado }) \times(0,6)}{(0,1) \times(60) \times(0,1)}
$$

$0,6=$ volume total da primeira etapa do ensaio $(\mathrm{mL})$.

$0,1=$ volume da primeira etapa $(\mathrm{mL})$ utilizado na segunda etapa do ensaio.

$60=$ tempo do ensaio em minutos.

$0,1=$ volume da amostra $(\mathrm{mL})$ utilizado no ensaio. 


\subsubsection{Protocolo Microplaca para determinação da atividade enzimática}

A reação se deu em duas etapas, ambas realizadas em microplaca e não em cubetas, como nos dois protocolos descritos acima. Na primeira etapa, a mistura da reação foi constituída de $0,05 \mathrm{~mL}$ de tampão Tris- $\mathrm{HCl}(0,05 \mathrm{M}), \mathrm{pH}$ 7,2; 0,2 mL de LAsparagina $(0,04 \mathrm{M}) ; 0,05 \mathrm{~mL}$ de amostra. A mistura foi incubada em estufa a $37^{\circ} \mathrm{C}$ por 60 minutos e a reação foi interrompida com a adição de 0,05 mL de TCA (1,5 M). Foram preparados tubos para o branco da amostra e o branco do substrato. No branco da amostra, o conteúdo de substrato foi substituído por tampão Tris- $\mathrm{HCl}$ $0,05 \mathrm{M}$. Já, para o branco do substrato, a quantidade de amostra que foi trocada por tampão Tris-HCl.

$\mathrm{Na}$ segunda etapa do teste, a mistura da reação foi constituída por $187,5 \mu \mathrm{L}$ de água purificada, $25 \mu \mathrm{L}$ da mistura resultante da primeira etapa e $37,5 \mu \mathrm{L}$ do reagente de Nessler (Merck). Essa mistura foi incubada a temperatura ambiente, durante 20 minutos. A absorbância resultante da reação entre o reagente de Nessler e a amônia formada foi medida em leitora de microplaca, a $450 \mathrm{~nm}$.

$$
U I / m L \text { enzima }=\frac{(\mu \mathrm{mol} \text { de NH3 liberado }) \times(0,35)}{(0,025) \times(60) \times(0,05)}
$$

$0,35=$ volume total da primeira etapa do ensaio $(\mathrm{mL})$.

0,025 = volume da primeira etapa $(\mathrm{mL})$ utilizado na segunda etapa do ensaio.

$60=$ tempo do ensaio em minutos.

$0,05=$ volume da amostra $(\mathrm{mL})$ utilizado no ensaio.

\subsubsection{Preparo dos reagentes e soluções utilizadas}

\subsubsection{Tampão Tris- $\mathrm{HCl} 0,05 \mathrm{M}$}

O preparo do Tampão Tris- $\mathrm{HCl}$ 0,05 M foi realizado através da solubilização de $3,03 \mathrm{~g}$ de Tris em $400 \mathrm{~mL}$ de água purificada. $\mathrm{O}$ pH do tampão foi ajustado com solução de $\mathrm{HCl}$ 1,0 M e, após o ajuste, adicionou-se água purificada até completar o 
volume para $500 \mathrm{~mL}$. Foram preparadas soluções tampão em dois valores de $\mathrm{pH}$, 7,2 e 8,6. O tampão foi armazenado sob refrigeração.

\subsubsection{Solução de L-Asparagina 0,04 M}

A solução de L-Asparagina foi preparada a partir da dissolução de $0,132 \mathrm{~g}$ de L-Asparagina em Tampão Tris- $\mathrm{HCl} 0,05 \mathrm{M}$, de $\mathrm{pH} 7,2$ ou 8,6. A solução foi preparada momentos antes da realização do experimento e armazenada sob refrigeração.

\subsubsection{Solução de L-Asparagina 0,189 M}

A solução de L-Asparagina foi preparada a partir da dissolução de $0,624 \mathrm{~g}$ de L-Asparagina em Tampão Tris- $\mathrm{HCl} 0,05 \mathrm{M}$, de $\mathrm{pH} 7,2$ ou 8,6. A solução foi preparada momentos antes da realização do experimento e armazenada sob refrigeração.

\subsubsection{Solução de ácido tricloroacético (TCA) 1,5M}

A solução foi preparada a partir da dissolução de 6,12 g de TCA em Tampão Tris- $\mathrm{HCl} 0,05 \mathrm{M}$, de $\mathrm{pH} 7,2$ ou 8,6. A solução foi preparada momentos antes da realização do experimento e armazenada sob refrigeração.

\subsubsection{Processo de ultrafiltração}

Para o processo de ultrafiltração das amostras, foram utilizados $10 \mathrm{~mL}$ do caldo filtrado proveniente do processo fermentativo. Foi utilizada membrana de 3,0 kDa (Vivaspin GE) para a realização da ultrafiltração sob as seguintes condições: $8000 \mathrm{rpm}, 25$ minutos, $4 \stackrel{\circ}{\mathrm{C}}$. Ao térmico do processo de ultracentrifugação, os volumes da amostra concentrada e da ultrafiltrada foram aferidos. 


\subsubsection{Processo de diálise}

A diálise das amostras obtidas a partir dos cultivos de micro-organismos em meio líquido foi realizada durante 24 horas, em câmara fria, com tampão Tris-HCl $0,001 \mathrm{M}(\mathrm{pH} 7,2)$ e membrana de celulose (Sigma-Aldrich). Durante as 24 horas, foram realizadas três trocas de tampão e, após esse período, a diálise foi finalizada e a amostra armazenada sob refrigeração. O fator de diluição foi calculado.

\subsubsection{Preparo do Tampão Tris- $\mathrm{HCl} 0,001 \mathrm{M}$}

O preparo do Tampão Tris- $\mathrm{HCl}$ 0,001 M foi realizado a partir da utilização de $80 \mathrm{~mL}$ do Tampão Tris- $\mathrm{HCl}$ 0,05 M, previamente preparado. Aos $80 \mathrm{~mL}$ foi adicionada água purificada até completar o volume para $4000 \mathrm{~mL}$. A solução tampão foi preparada no dia anterior a realização da diálise e mantida sob refrigeração.

\subsubsection{Avaliação de diferentes condições de centrifugação da amostra}

Após a obtenção do extrato bruto, a partir do processo de filtração utilizando papel Whatman $n^{\circ} 1$, que visa à separação do caldo e do micélio, foram realizados diferentes processos de centrifugação com o extrato fúngico. Os parâmetros utilizados variaram entre a não centrifugação da amostra, até a rotação máxima de $4000 \mathrm{~g}$, durante 5 minutos. Após estes processos, as amostras foram dialisadas e a atividade enzimática foi determinada.

\subsubsection{Avaliação de diferentes tempos de incubação durante a reação de determinação da atividade enzimática}

Após a obtenção da amostra filtrada e dialisada, a atividade enzimática foi determinada a cada 10 minutos de reação, até o tempo máximo de 60 minutos. 0 melhor tempo de incubação foi determinado a partir do maior valor de atividade encontrado. 


\subsubsection{Avaliaçao de diferentes concentrações de substrato na determinação da atividade enzimática}

Após a obtenção da amostra filtrada e dialisada, a atividade enzimática foi avaliada frente a diferentes concentrações de substratos utilizados durante a reação. As concentrações de substratos testadas variaram de 0,02 $\mathrm{M}$ até $0,16 \mathrm{M}$.

\subsection{TEOR DE PROTEÍNAS TOTAIS}

O teor de proteínas totais foi determinado como descrito por Bradford (1976). A reação foi iniciada pela adição de $0,1 \mathrm{~mL}$ de amostra a $1,0 \mathrm{~mL}$ do reagente. Após cinco minutos, foi feita a leitura a $595 \mathrm{~nm}$. Para os cálculos da concentração de proteína, foi preparada uma curva padrão utilizando albumina de soro bovino (BSA), em concentrações que variaram de 5,0 até $200 \mu \mathrm{g} / \mathrm{mL}$ (BRADFORD, 1976).

\subsubsection{Preparo do Reagente de Bradford}

O preparo do reagente de Bradford foi realizado através da dissolução de $100 \mathrm{mg}$ de Azul de Comassie G-250 (BIORAD) em uma solução que continha a seguinte mistura: $50 \mathrm{~mL}$ de metanol a $95 \%$ e $100 \mathrm{~mL}$ de ácido fosfórico a $85 \%$. Após a completa dissolução do corante, adicionou-se água até completar o volume para 1,0 litro. Essa solução foi filtrada e estocada em frasco âmbar, sob refrigeração.

\subsection{MEDIDA DA BIOMASSA FÚNGICA}

Para a determinação do crescimento fúngico, a medida da biomassa foi analisada a partir de um método direto denominado peso seco. É um dos métodos mais utilizados para medir o crescimento dos fungos desenvolvidos em meios não sólidos. Consiste em separar a biomassa do caldo de cultura, por filtração, e secar a biomassa obtida em estufa, aproximadamente a $105^{\circ} \mathrm{C}$, até alcançar peso constante (ESPOSITO;AZEVEDO, 2010). 


\subsection{ISOLAMENTO E IDENTIFICAÇÃO DOS FUNGOS FILAMENTOSOS}

\subsubsection{Isolamento dos fungos do solo}

Os fungos filamentosos isolados do bioma Cerrado da região Centro-Oeste brasileira foram identificados fenotipicamente pelo professor Dr. Luís Roberto Batista, do Laboratório de Microbiologia de Alimentos, da Universidade Federal de Lavras (UFLA). As diferentes espécies isoladas e identificadas encontram-se depositadas na Micoteca do Laboratório de Enzimologia, do Instituto de Ciências Biológicas, da Universidade de Brasília (UnB), dentro do âmbito da rede SisBiota Brasil (Sistema Nacional de Pesquisa em Biodiversidade - CNPq) de fungos filamentosos. A autorização de acesso e de remessa de amostras de componente do patrimônio genético possui número 010770/2013-5 e apresenta-se sob supervisão do Professor Dr. Edivaldo Ximenes. O procedimento de isolamento dos fungos filamentosos foi realizado a partir do método de plaqueamento direto e diluição seriada em placas de petri e a Figura 3 representa, de forma simplificada, esse processo.
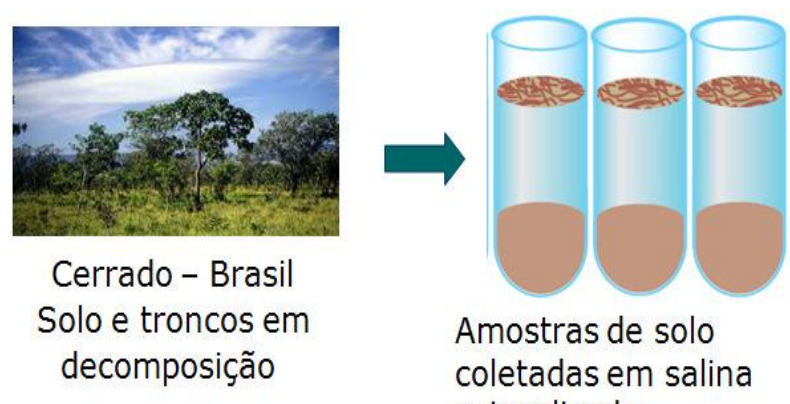

Amostras de solo coletadas em salina esterelizada

Isolamento por plaqueamento direto e diluição seriada.
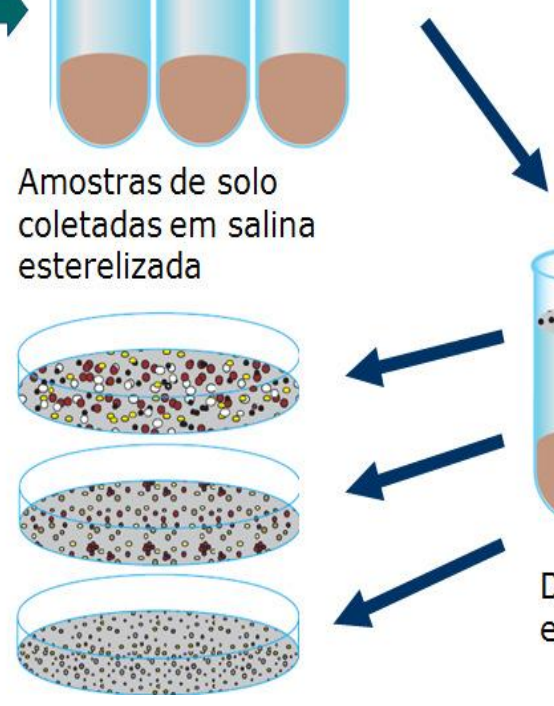

Meio + Antibiótico

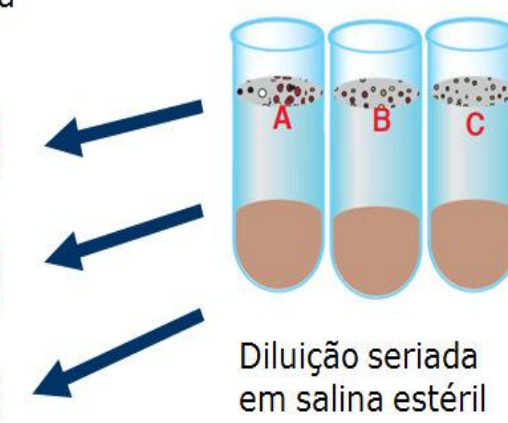

Figura 3 - Esquema simplificado do isolamento de fungos filamentosos do solo do bioma Cerrado da região Centro-Oeste brasileira (BARROS, 2014). 


\subsubsection{Isolamento dos fungos endofíticos}

$O$ isolamento dos fungos endofíticos de espécies importantes $\mathrm{e}$ características do bioma Cerrado da região Centro-Oeste brasileira foi realizado a partir da obtenção de folhas das espécies vegetais. Inicialmente, as folhas foram lavadas em água corrente e com a utilização de detergente líquido neutro. Após esssa etapa, foi realizada a descontaminação da superfície da folha, por imersão, com etanol e hipoclorito de sódio (com teor de cloro ativo de $2 \%$ ). Depois, as folhas foram lavadas em três recipientes distintos contendo água destilada previamente autoclavada. Após a descontaminação e lavagem, foram obtidos pequenos fragmentos das folhas, com o auxílio de pinças e tesouras previamente autoclavadas, que foram aplicados na superfície de placas de petri contendo $20 \mathrm{~mL}$ de meio de cultura dextrose Sabouraud. Foram preparadas duas placas para os controles negativos de crescimento microbiano. A primeira utilizou uma amostra da última água de lavagem e a segunda foi realizada a partir da impressão da superfície da folha, após a descontaminação (MESQUITA, 2011).

Todas as placas foram incubadas a $28^{\circ} \mathrm{C}$, até o crescimento das diferentes colônias fúngicas. Repiques sucessivos foram realizados, até o completo isolamento de apenas uma espécie por placa (MESQUITA, 2011).

\subsection{PREPARAÇÃO DO INÓCULO}

Todos os isolados de fungos, previamente armazenados em glicerol a $-80^{\circ} \mathrm{C}$ foram reativados em meio de cultura batata-dextrose-ágar (BDA), a $28 \stackrel{\circ}{\circ}$, durante cerca de sete dias ou até seu completo crescimento. Discos de cinco $\mathrm{mm}$ de micélio foram utilizados nos testes para a seleção de fungos produtores em meio sólido (Teste do Halo), enquanto que, nos testes para a produção da enzima em meio líquido, $1,0 \mathrm{~mL}$ de uma solução contendo cerca de $1 \times 10^{7}$ esporos $/ \mathrm{mL}$ foi utilizada como inóculo. Essa solução era composta por solução salina $0,9 \%$ e tween $1 \%$ na proporção de 49:1 e a contagem de esporos foi realizada em Câmara de Neubauer. 


\subsection{SELEÇÃO DE FUNGOS QUANTO À PRODUÇÃO DE L-ASPARAGINASE EM MEIO SÓLIDO}

Todos os isolados de fungos foram cultivados em meio de cultura batatadextrose-ágar (BDA) durante sete dias ou até seu completo crescimento. Discos de cinco $\mathrm{mm}$ de micélio foram transferidos para placas de Petri contendo o meio ágar CDM. O ensaio em placa de ágar foi utilizado para selecionar possíveis fungos produtores de L-Asparaginase. $O$ meio foi composto por glicose $(2,0 \mathrm{~g} / \mathrm{L})$, LAsparagina (10,0 g/L), $\mathrm{KH}_{2} \mathrm{PO}_{4}(1,52 \mathrm{~g} / \mathrm{L}), \mathrm{KCl}(0,52 \mathrm{~g} / \mathrm{L}), \mathrm{MgSO}_{4} .7 \mathrm{H}_{2} \mathrm{O}(0,52 \mathrm{~g} / \mathrm{L})$, $\mathrm{CuNO}_{3} .3 \mathrm{H}_{2} \mathrm{O}(0,001 \mathrm{~g} / \mathrm{L}), \mathrm{ZnSO}_{4} .7 \mathrm{H}_{2} \mathrm{O}(0,001 \mathrm{~g} / \mathrm{L}), \mathrm{FeSO}_{4} .7 \mathrm{H}_{2} \mathrm{O}(0,001 \mathrm{~g} / \mathrm{L}), \mathrm{pH} 6,2$ e suplementado com vermelho de fenol $(0,009 \%$ concentração final) (GULATI; SAXENA;GUPTA, 1997), que foi utilizado como indicador de possível produção de L-Asparaginase. Placas sem L-Asparagina foram utilizadas como controle. Todas as placas foram incubadas a $30^{\circ} \mathrm{C}$, durante cinco dias. A zona avermelhada formada indica uma possível produção de L-Asparaginase pelo fungo.

\subsection{SELEÇÃO DE FUNGOS QUANTO À PRODUÇÃO DE L-ASPARAGINASE EM MEIO LÍQUIDO}

As condições de cultivo em meio líquido foram realizadas em duas etapas:

$1^{\text {a) }}$ Etapa Pré-fermentativa:

O objetivo desta primeira etapa foi a obtenção de massa micelial. Um mililitro contendo cerca de $1 \times 10^{7}$ esporos foi inoculado em erlenmeyers de $250 \mathrm{~mL}$ contendo $50 \mathrm{~mL}$ do meio. $\mathrm{O}$ meio de cultura foi composto de: Sabouraud 3\% e extrato de levedura 1\%; e o pH foi ajustado para 8,5 com hidróxido de potássio $(\mathrm{KOH}) 1,0 \mathrm{M}$. A

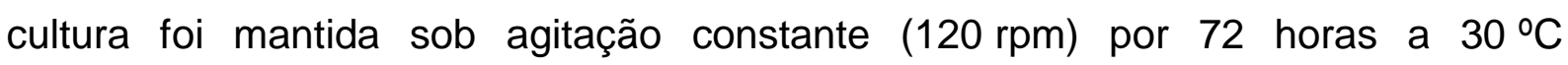
(LOUREIRO, 2010).

2a) Etapa Fermentativa:

Em seguida na $2^{\text {a }}$ etapa, fermentativa, cujo objetivo foi a produção de LAsparaginase, o micélio foi filtrado e reincubado em erlenmeyers de $250 \mathrm{~mL}$ contendo $50 \mathrm{~mL}$ de meio CDM, composto por glicose (2,0 g/L), L-Prolina $(20,0 \mathrm{~g} / \mathrm{L})$, $\mathrm{KH}_{2} \mathrm{PO}_{4}(1,52 \mathrm{~g} / \mathrm{L}), \mathrm{KCl}(0,52 \mathrm{~g} / \mathrm{L}), \mathrm{MgSO}_{4} .7 \mathrm{H}_{2} \mathrm{O}(0,52 \mathrm{~g} / \mathrm{L}), \mathrm{ZnSO}_{4} .7 \mathrm{H}_{2} \mathrm{O}(0,01 \mathrm{~g} / \mathrm{L})$, $\mathrm{FeSO}_{4} \cdot 7 \mathrm{H}_{2} \mathrm{O}(0,01 \mathrm{~g} / \mathrm{L})$ e Cu. $\mathrm{SO}_{4} \cdot 5 \mathrm{H}_{2} \mathrm{O}(0,0087 \%)$ e $\mathrm{pH}$ ajustado para 8,5 . As 
condições da $1^{\underline{a}}$ etapa foram mantidas na $2^{\mathrm{a}}$ etapa, exceto pelo tempo de incubação que foi de cinco dias. Por último, o fluido da cultura foi separado do micélio por filtração utilizando papel de filtro Whatman ํo 1 e armazenado em refrigerador (LOUREIRO, 2010).

\subsection{PRESERVAÇÃO DOS FUNGOS PRODUTORES DE L-ASPARAGINASE}

Os fungos selecionados foram mantidos (depositados) na coleção de culturas microbianas do Instituto de Biologia da UnB e foram preservados pelo método do congelamento a $-80^{\circ} \mathrm{C}$ (NAKASONE; PETERSON;JONG, 2004). A solução contendo glicerol e tween 80 , utilizada no armazenamento fúngico, foi preparada a partir da dissolução de $0,9 \mathrm{~g}$ de cloreto de sódio $(\mathrm{NaCl})$ em $50 \mathrm{~mL}$ de água purificada. Após a completa dissolução, foram acrescentados a mistura salina $50 \mathrm{~mL}$ de glicerol e $0,2 \mathrm{~mL}$ de tween 80 . A solução foi fracionada em criotubos $(1,0 \mathrm{~mL}) \mathrm{e}$ autoclavada durante 20 minutos a $120^{\circ} \mathrm{C}$.

\subsection{AVALIAÇÃO DA MELHOR CONDIÇÃO DE CULTIVO PARA A PRODUÇÃO ENZIMÁTICA EM SHAKER}

Foram testados diferentes parâmetros de cultivo a fim de avaliar a melhor condição de produção enzimática de L-Asparaginase em shaker. A partir da utilização do meio líquido CDM (conforme descrito no item 4.7), variaram-se as fontes de nitrogênio e carbono utilizadas, além da realização, ou não, da etapa préfermentativa (também descrita no item 4.7). Diferentes valores de $\mathrm{pH}$ inicial do meio de cultivo também foram testados, variando de 4,5 até 8,5. A Tabela 2 apresenta as fontes de nitrogênio e carbono utilizadas no experimento. 
Tabela 2 - Fontes de nitrogênio e de carbono utilizadas na composição do meio de cultivo CDM.

\begin{tabular}{cc}
\hline Fonte & Substâncias e concentrações utilizadas \\
\hline \multirow{2}{*}{ Nitrogênio } & L-Asparagina $(2 \%)$ \\
& L-Prolina $(2 \%)$ \\
& L-Prolina $(2 \%)+$ Ácido glutâmico $(0,5 \%)$ \\
Carbono & Glicose $(0,2 \%)$ \\
& Amido $(0,2 \%)$ \\
\hline
\end{tabular}

\subsection{ANÁLISE ESTATÍSTICA}

Todos os resultados apresentados representam a média dos experimentos, \pm desvio padrão de, no mínimo, três ensaios diferentes. As análises estatísticas foram obtidas utilizando GraphPad Prism versão 5.01 e, quando necessário, os valores encontrados foram comparados a partir do teste one-way ANOVA, seguido pelo teste de análise de Tukey. 


\section{RESULTADOS E DISCUSSÃO}

\subsection{PADRONIZAÇÃO DA METODOLOGIA DE DETERMINAÇÃO DA ATIVIDADE ENZIMÁTICA}

Diferentes métodos podem ser utilizados para a quantificação da produção de L-Asparaginase em amostras biológicas. O método condutimétrico, descrito por Drainas e Drainas, baseado no aumento da condutividade que ocorre devido à produção de amoníaco e/ou aspartato, é um destes (DRAINAS, D.;DRAINAS, 1985). Outra forma de identificação da enzima L-Asparaginase foi proposta por Padjak e Padjak $(1974,1972)$, em um método baseado na formação de um complexo branco insolúvel a partir da reação do tetrafenilborato de sódio com o íon amônio $\left[\mathrm{NaB}\left(\mathrm{C}_{6} \mathrm{H}_{5}\right)^{4}-\mathrm{NH}_{4}{ }^{+}\right]$. A amostra contendo a enzima e outras proteínas é submetida à eletroforese não desnaturante e, após a separação das proteínas, o gel é então colocado em contato com tetrafenilborato, formando um halo branco em torno da banda correspondente à L-Asparaginase (PADJAK;PADJAK, 1972, 1974). Drainas e colaboradores (1977) descreveram um método fundamentado na formação de $\beta$ hidroximato aspártico a partir de asparagina e hidroxilamina (DRAINAS, C.; KINGHORN;PATEMAN, 1977).

Apesar da existência de diferentes metodologias, as mais empregadas para determinação da atividade de L-Asparaginase são aquelas baseadas na determinação da amônia liberada pela L-Asparagina, como resultado da ação da enzima, utilizando-se o reagente de Nessler, onde se pode verificar a formação de coloração amarelo-alaranjada. São métodos espectrofotométricos descritos como de boa reprodutibilidade, mas que requerem atenção (GULATI; SAXENA;GUPTA, 1997; WINK, 2009; IMADA et al., 1973).

Embora a utilização de ensaios espectrofotométricos de Nesslerização esteja bem estabelecida, são utilizadas as mais variadas concentrações e volumes de tampão, substrato e amostra durante a reação. Além disso, após a separação da biomassa microbiana e do caldo fermentado, a amostra é processada de diversas maneiras (GULATI; SAXENA;GUPTA, 1997; LOUREIRO, 2010; RANI; SUNDARAM;VASANTHA, 2012; SHRIVASTAVA et al., 2012). Assim, a padronização de um método seguro e eficaz frente ao preparo da amostra e à 
determinação da atividade da enzima L-Asparaginase foi de grande importância para que ensaios de cinética fossem confiáveis, tanto para enzimas purificadas quanto para extratos brutos obtidos a partir de fermentações microbianas.

No presente estudo, foi realizada a análise de três diferentes metodologias utilizando o princípio de Nesslerização e, além disso, diferentes parâmetros durante o preparo da amostra também foram testados e avaliados. As amostras utilizadas nos testes foram a enzima L-Asparaginase purificada, obtida a partir de Escherichia coli (Sigma-Aldrich) e a enzima de origem fúngica, obtida a partir de culturas da cepa de Aspergillus terreus (PC-1.7.A), anteriormente descrita como produtora (LOUREIRO, 2010).

Os primeiros testes realizados utilizaram a enzima purificada. Foram preparadas duas concentrações conhecidas da enzima e as três metodologias, descritas anteriormente no item 4.1, testadas e avaliadas. Conforme demonstrado na Tabela 3, os valores de atividade enzimática encontrados, a partir da utilização da solução de concentração enzimática de $1,0 \mathrm{UI} / \mathrm{mL}$, foram diferentes quando as três metodologias foram comparadas.

Tabela 3 - Valores de atividade enzimática obtidos a partir da utilização de uma solução de concentração conhecida da enzima L-Asparaginase $(1,0 \mathrm{Ul} / \mathrm{mL})$.

\begin{tabular}{cccc}
\hline Metodologia & \multicolumn{3}{c}{ Atividade enzimática $(\mathrm{Ul} / \mathrm{mL})$} \\
\hline Imada & \multicolumn{3}{c}{ Não foi possível medir* } \\
Microplaca & 1,195 & 1,189 & 1,138 \\
Sigma & 0,820 & 0,854 & 0,779 \\
\hline
\end{tabular}

${ }^{*} \mathrm{~A}$ amostra precipitou, o que impossibilitou a leitura.

Os resultados demonstram que o protocolo Imada (modificado) obteve resultados que impossibilitaram a leitura em espectrofotômetro, com formação de precipitado nesta concentração enzimática. As outras duas metodologias apresentaram resultados próximos ao valor real de concentração da solução enzimática. O mesmo teste foi realizado ainda com solução enzimática de concentração maior, 2,0 Ul/mL (Tabela 4). E os resultados demonstram que, apesar dos valores serem muito semelhantes entre os dois testes, o teste da Microplaca foi mais exato, atingindo valores mais próximos da concentração real. 
Tabela 4 - Valores de atividade enzimática obtidos a partir de uma solução de concentração conhecida da enzima L-Asparaginase $(2,0 \mathrm{UI} / \mathrm{mL})$, encontrados a partir da realização de duas diferentes metodologias.

\begin{tabular}{cccc}
\hline Metodologia & \multicolumn{3}{c}{ Atividade enzimática $(\mathrm{UI} / \mathrm{mL})$} \\
\hline Microplaca & 1,969 & 1,953 & 1,882 \\
Sigma & 1,779 & 1,879 & 1,733 \\
\hline
\end{tabular}

Os valores encontrados demonstram que o protocolo da Sigma, em ambas concentrações da enzima purificada, apresentou valores próximos ao real, entretanto, quando comparado ao protocolo realizado em microplaca, teve resultado inferior.

As três metodologias foram testadas também a partir da utilização da enzima fúngica, produzida a partir de um cultivo de $A$. terreus. Após a obtenção do caldo fermentado, a atividade enzimática foi quantificada. Foi possível perceber que as metodologias descritas por Imada e a da Microplaca não puderam ser utilizadas na quantificação, pois, após a adição do regente de Nessler à reação, ocorreu a formação de um precipitado, impossibilitando a leitura em espectrofotômetro. Quando se adiciona o reagente de Nessler [solução alcalina de tetraiodomercurato (II) de potássio] a uma solução que contém amônia livre, a mesma reage com o reagente de forma rápida, porém não instantaneamente, e forma um composto castanho alaranjado que, depois de um longo período, fica em solução coloidal e flocula. Essa reação pode ser representada por: $2 \mathrm{~K}_{2}\left[\mathrm{Hgl} \mathrm{I}_{4}\right]+2 \mathrm{NH}_{3}=\mathrm{NH}_{2} \mathrm{Hg}_{2} \mathrm{I}_{3}+4 \mathrm{KI}$ $+\mathrm{NH}_{4} \mathrm{l}$ (VOGEL, 1981).

A formação do precipitado durante a realização das metodologias Imada e Microplaca não se deve a um longo período de tempo entre a reação e leitura em espectrofotômetro, visto que ocorreu muito rapidamente após a adição do reagente de Nessler à amostra. Uma possível explicação para a ocorrência do fato pode ser entendida a partir da grande quantidade de amônia livre que pode estar presente no caldo fermentado de origem fúngica. Sabendo que a leitura colorimétrica deve ser realizada antes da floculação/precipitação (VOGEL, 1981), esta não pôde ser realizada durante a execução dos protocolos Imada e Microplaca testados nesta etapa do trabalho. 
A reação de precipitação não ocorreu durante a execução do protocolo da Sigma, entretanto, um outro problema foi encontrado nas três metodologias avaliadas. A absorbância encontrada para o tubo branco do teste e para os tubos testes foram muito semelhantes, o que reforça a suposição de que ocorre a formação de uma quantidade muito superior de amônia durante o processo fermentativo, quando comparada àquela formada apenas durante o tempo de incubação do teste. A produção de amônia durante a fermentação pode ser explicada devido ao fato de que a única fonte de nitrogênio presente no meio de cultivo fermentativo são os aminoácidos. Todo aminoácido, ao sofrer desaminação oxidativa, irá produzir amônia $\left(\mathrm{NH}_{3}\right)$ (NELSON;COX, 2002).

Diante do fato de que a quantidade de amônia nas amostras de culturas fúngicas foram bem mais elevadas do que aquelas obtidas durante a reação enzimática, tornou-se imprescindível a retirada deste interferente. Assim, duas técnicas foram testadas: a primeira, foi a utilização de uma membrana de ultrafiltração de 3,0 kDa (Vivaspin - GE); a segunda técnica avaliada foi a realização do processo de diálise, utilizando membrana de celulose (Sigma-Aldrich), durante 24 horas. Os resultados obtidos podem ser observados na Figura 4.
(A)
(B)
(C)
(D)

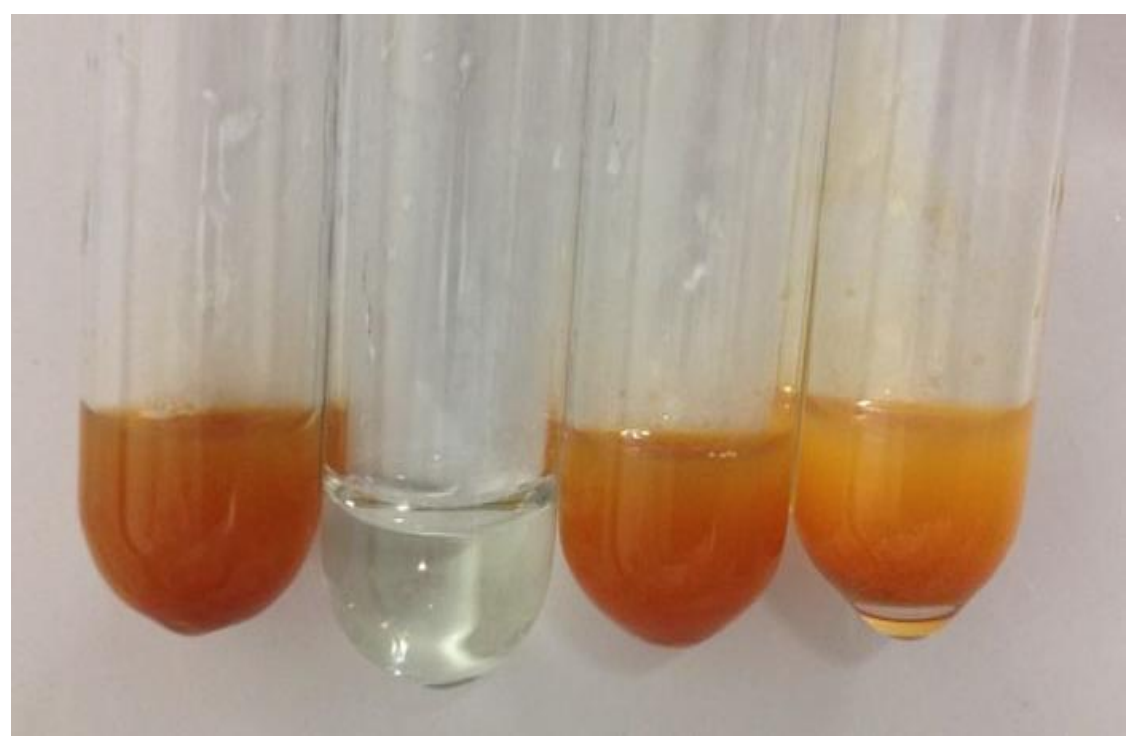

Figura 4 - Amostras do caldo fermentado, após a realização de diferentes técnicas, a fim de eliminar a amônia formada durante o processo fermentativo em meio líquido. (A) Extrato bruto; (B) Amostra dialisada; (C) Amostra concentrada em membrana de ultrafiltração - 3,0 kDa; (D) Amostra ultrafiltrada em membrana de ultrafiltração - 3,0 kDa. 
De acordo com Faedo e colaboradores (2013), a operação de separação por membranas é baseada em mecanismos físicos e não envolve processos químicos, biológicos ou trocas térmicas. Refere-se apenas à separação dos diferentes componentes de uma mistura pela rejeição daqueles que possuem ou não tamanho para atravessar os poros da membrana. Diferentes processos de separação utilizando as mais variadas membranas podem ser executados. Muitos princípios ou mecanismos de separação podem ser aplicados visando o fracionamento de diferentes compostos químicos presentes em uma mistura (FAEDO et al., 2013).

A partir da visualização da Figura 4, pode-se observar que a amostra dialisada (Figura 4B) foi a única que apresentou resultado positivo para a eliminação da amônia proveniente do processo fermentativo. Após a adição do reagente de Nessler nas respectivas amostras, foi a única que não precipitou e nem ocorreu alteração de coloração. Além disso, verifica-se, a partir da Tabela 5, que não foram encontrados valores positivos de absorbância para as amostras dialisadas. $\mathrm{Na}$ referida tabela, pode-se visualizar apenas os resultados obtidos com a realização do protocolo Sigma, isso por que, durante a realização das outras duas metodologias (Imada e Microplaca), ocorreu a formação de precipitados e, por isso, as amostras não-dialisadas não puderam ser lidas em espectrofotômetro, o que impossibilitou a comparação com os resultados encontrados após a diálise.

Tabela 5 - Valores de absorbância encontrados antes e após a realização do processo de diálise.

\begin{tabular}{cccc}
\hline $\begin{array}{c}\text { A. terreus } \\
\text { (PC-1.7.A) }\end{array}$ & \multicolumn{3}{c}{ Absorbância 436 nm (Sigma) } \\
\hline $\begin{array}{c}\text { Amostra Não- } \\
\text { dialisada }\end{array}$ & 0,292 & 0,301 & 0,289 \\
Amostra Dialisada & 0,000 & 0,000 & 0,000 \\
\hline
\end{tabular}

A força motriz que rege o movimento entre as membranas em um processo de separação depende das características da membrana e, em geral, são aplicados gradientes de pressão ou concentração. A ultrafiltração é um exemplo de processo que utiliza o gradiente de pressão como força motriz, enquanto que, na diálise, o processo de transporte de constituintes ocorre a partir da utilização de uma membrana semipermeável em que a força motriz resultante é a diferença de concentração. A passagem de íons e substâncias de baixos pesos moleculares 
ocorre ao mesmo tempo em que se preservam aquelas com pesos mais altos (FAEDO et al., 2013).

Metodologia semelhante foi relatada em estudos anteriores. Loureiro (2010), em trabalho que avaliou a produção de L-Asparaginase por A. terreus (cepa PC1.7.A), realizou o processo de diálise após a obtenção do fluido da cultura (LOUREIRO, 2010). Patro e colaboradores (2014), em estudo que estabeleceu um novo meio de cultura para a produção de L-Asparaginase fúngica, também realizaram o processo de diálise antes da realização do ensaio enzimático (PATRO et al., 2014).

Novas quantificações de atividade enzimática foram realizadas, com a amostra dialisada, a partir das diferentes metodologias propostas. Os resultados obtidos podem ser obervados na Tabela 6 e demonstram a detecção, a partir da utilização do protocolo da Sigma, de valores de atividade muito mais baixos, quando comparados aos valores obtidos a partir da utilização das outras duas metodologias testadas neste estudo (Imada e Microplaca).

Tabela 6 - Valores de atividade enzimática obtidos a partir de uma amostra dialisada, de um único cultivo de $A$. terreus, utilizando as diferentes metodologias propostas neste trabalho.

\begin{tabular}{clcc}
\hline Metodologia & \multicolumn{3}{c}{ Atividade enzimática $(\mathrm{UI} / \mathrm{mL})$} \\
\hline Imada & 0,182 & 0,189 & 0,197 \\
Microplaca & 0,130 & 0,126 & 0,124 \\
Sigma & 0,063 & 0,035 & 0,057 \\
\hline
\end{tabular}

Esse fato poderia ser explicado devido à grande diluição realizada durante a execução do protocolo da Sigma, o que pode ter causado perda de sensibilidade do método. Diante desse resultado, foi realizado um experimento utilizando diferentes concentrações da enzima pura, a fim de demonstrar a precisão e exatidão dos três métodos avaliados neste trabalho. Segundo legislação oficial, devem ser realizadas no mínimo cinco replicatas em, pelo menos, cinco concentrações (BRASIL, 2012). Foram realizadas cinco repetições deste ensaio, utilizando seis concentrações enzimáticas diferentes, e os resultados podem ser visualizados na Tabela 7. 
Tabela 7 - Valores (média das cinco repetições) de atividade enzimática obtidos a partir da realização das três metodologias, utilizando soluções com diferentes concentrações da enzima L-Asparaginase purificada (Sigma-Aldrich).

\begin{tabular}{ccccccc}
\hline Metodologia & \multicolumn{5}{c}{ Concentrações da enzima L-Asparaginase purificada } \\
\hline \multirow{2}{*}{ Imada } & $1 \mathrm{Ul} / \mathrm{mL}$ & $0,5 \mathrm{Ul} / \mathrm{mL}$ & $0,3 \mathrm{Ul} / \mathrm{mL}$ & $0,2 \mathrm{Ul} / \mathrm{mL}$ & $0,1 \mathrm{Ul} / \mathrm{mL}$ & $0,05 \mathrm{Ul} / \mathrm{mL}$ \\
\cline { 2 - 6 } Microplaca & $*$ & 0,595 & 0,361 & 0,326 & 0,189 & 0,082 \\
Sigma & 1,256 & 0,569 & 0,313 & 0,206 & 0,124 & 0,051 \\
& 0,791 & 0,361 & 0,139 & 0,036 & 0,019 & 0,018 \\
\hline
\end{tabular}

* Não foi possível medir. A amostra precipitou, o que impossibilitou a leitura em espectrofotômetro.

Após análise estatística dos resultados obtidos nas cinco replicatas, foram encontrados valores de precisão e exatidão adequados a partir da utilização do protocolo da Microplaca (Tabela 8). O protocolo Imada, apesar de possuir uma precisão muito parecida com o da Microplaca, obteve exatidão muito fora dos padrões aceitáveis, detectando, em todas as leituras, valores muito acima dos reais. O protocolo Sigma apresentou resultados ainda menos precisos e exatos, o que pode ser explicado pela falta de sensibilidade a partir da utilização de concentrações baixas da enzima.

Tabela 8 - Valores (média das seis concentrações testadas) de precisão e exatidão obtidos para as três metodologias testadas.

\begin{tabular}{ccc}
\hline Metodologia & $\begin{array}{c}\text { Coeficiente de Variação (\%) } \\
\text { Média experimental }\end{array}$ & $\begin{array}{c}\text { Exatidão (\%) } \\
\text { Média experimental }\end{array}$ \\
\hline Imada & 11,26 & 151,38 \\
Microplaca & 10,69 & 112,35 \\
Sigma & 50,99 & 45,24 \\
\hline
\end{tabular}

A precisão de um método bioanalítico representa a proximidade dos resultados obtidos por repetidas aferições de múltiplas alíquotas. Considerando que a precisão, expressa como desvio padrão relativo (DPR) ou coeficiente de variação (CV\%), não deve admitir valores superiores a 15\% (BRASIL, 2012), os resultados encontrados para cada concentração analisada, durante a execução do protocolo da 
Microplaca, mostraram que a metodologia desenvolvida pode ser considerada precisa (Tabela 9).

Tabela 9 - Valores obtidos para a precisão do protocolo da Microplaca, a partir da utilização de seis concentrações diferentes.

\begin{tabular}{cccc}
\hline $\begin{array}{c}\text { Valor real } \\
(\mathbf{U l} / \mathbf{m L})\end{array}$ & $\begin{array}{c}\text { Valor encontrado } \\
(\mathbf{U l} / \mathbf{m L})\end{array}$ & $\begin{array}{c}\text { Desvio } \\
\text { padrão }\end{array}$ & $\begin{array}{c}\text { Coeficiente de } \\
\text { variação }(\%)\end{array}$ \\
\hline $\mathbf{1 , 0}$ & 1,256 & 0,070 & 5,604 \\
$\mathbf{0 , 5}$ & 0,569 & 0,081 & 14,194 \\
$\mathbf{0 , 3}$ & 0,313 & 0,029 & 9,169 \\
$\mathbf{0 , 2}$ & 0,206 & 0,025 & 12,023 \\
$\mathbf{0 , 1}$ & 0,124 & 0,012 & 9,805 \\
$\mathbf{0 , 0 5}$ & 0,051 & 0,006 & 13,380 \\
\hline
\end{tabular}

A exatidão é definida como a concordância entre o resultado de um ensaio e um valor de referência (BRASIL, 2012). É calculada como porcentagem de recuperação da quantidade conhecida do analito adicionado à amostra, ou como a diferença porcentual entre as médias e o valor verdadeiro aceito, acrescida dos intervalos de confiança (FARINELLI, 2008). Para a obtenção da exatidão do método que apresentou a melhor precisão (Microplaca), pode-se analisar os resultados encontrados na Tabela 10. 
Tabela 10 - Valores de exatidão obtidos a partir da execução da metodologia da Microplaca.

\begin{tabular}{ccc}
\hline $\begin{array}{c}\text { Valor real } \\
(\mathrm{UI} / \mathrm{mL})\end{array}$ & $\begin{array}{c}\text { Valor encontrado } \\
(\mathrm{Ul} / \mathrm{mL})\end{array}$ & $\begin{array}{c}\text { Exatidão } \\
(\%)\end{array}$ \\
\hline $\mathbf{1 , 0}$ & 1,256 & 125,58 \\
$\mathbf{0 , 5}$ & 0,569 & 113,96 \\
$\mathbf{0 , 3}$ & 0,313 & 104,40 \\
$\mathbf{0 , 2}$ & 0,206 & 103,00 \\
$\mathbf{0 , 1}$ & 0,124 & 124,40 \\
$\mathbf{0 , 0 5}$ & 0,051 & 102,8 \\
\hline
\end{tabular}

Um método bioanalítico é considerado exato quando os valores obtidos experimentalmente tenham uma flutuação máxima de $15 \%$ em relação a média teórica, ou seja, de 85 a 115\% (BRASIL, 2012). Os resultados obtidos com a metodologia da Microplaca apresentaram apenas dois pontos, dentre os seis testados, que não estão de acordo com a literatura oficial, uma vez que para $1,0 \mathrm{UI} / \mathrm{mL}$ o valor de exatidão foi superior ao valor teórico em $25,58 \%$ e na concentração de $0,1 \mathrm{Ul} / \mathrm{mL}$, em 24,40\% (Tabela 10).

Os resultados obtidos com a utilização das metodologias Imada e Sigma não foram suficientemente adequados, apresentando valores de precisão e exatidão muito superiores aos limites preconizados pela Resolução de Diretoria Colegiada (RDC) ํㅡ 27, de 17 de maio de 2012, publicada pela ANVISA. O protocolo da Microplaca, entretanto, mostrou-se uma opção mais segura a ser utilizada, apresentando valores médios de precisão e exatidão dentro dos limites oficiais.

Diante dos resultados positivos obtidos a partir do metodologia da Microplaca, a linearidade do método também foi determinada, utilizando-se o coeficiente de regressão linear da curva analítica das soluções de diferentes concentrações enzimáticas, preparadas a partir da enzima pura. $O$ valor do coeficiente de regressão linear é considerado o indicador de linearidade do método, visto que, as concentrações analisadas devem corresponder, proporcionalmente, às absorbâncias encontradas (FARINELLI, 2008). Como resultado, o coeficiente de regressão linear 
obtido na curva analítica apresentada na Figura 5 apresentou o valor de 0,9961, o que garante a linearidade do método.

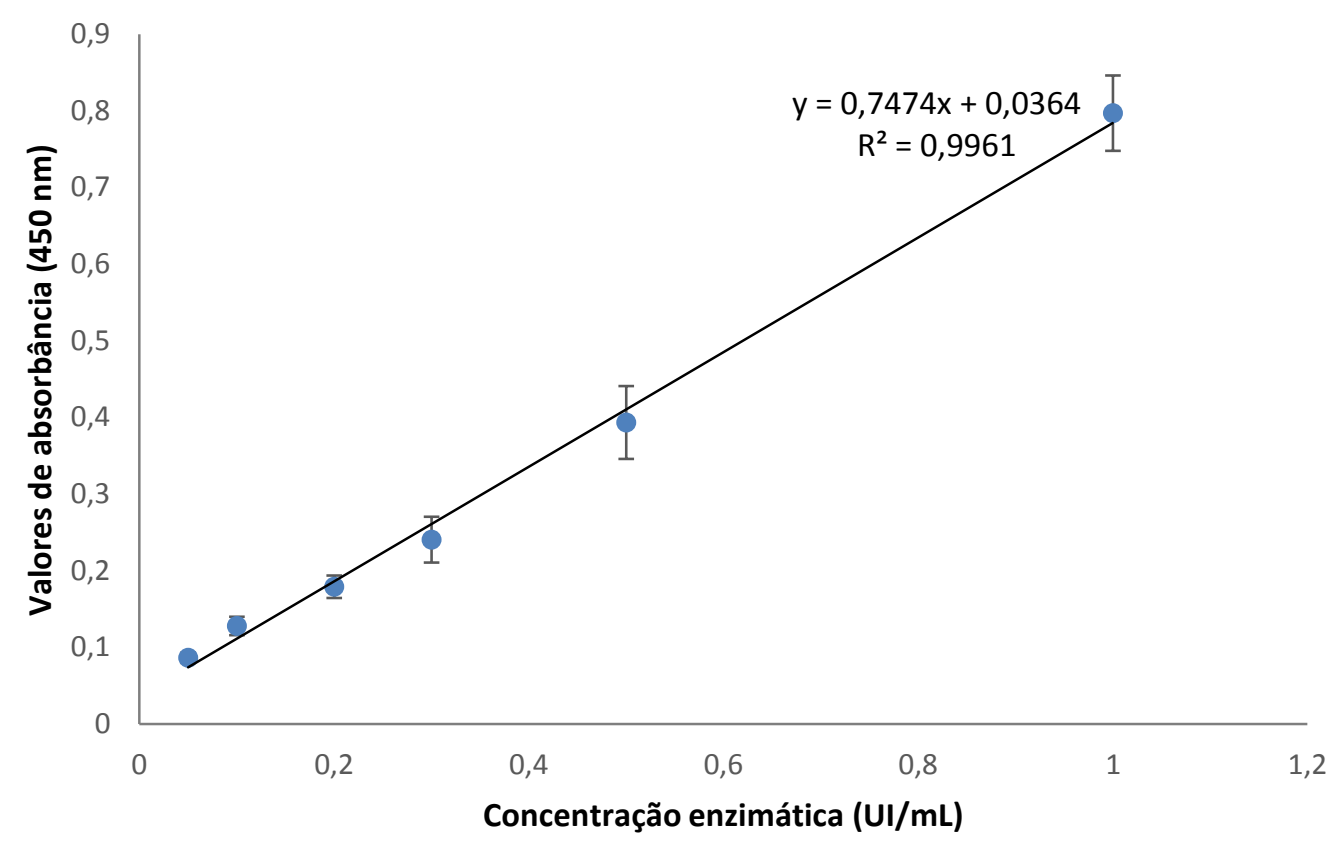

Figura 5 - Curva analítica de L-Asparaginase (Sigma-Aldrich)

Dentre os três protocolos estudados, o da Microplaca apresentou os melhores resultados de precisão e exatidão. O protocolo Imada parece superestimar os valores de atividade enzimática, apresentando uma precisão de 11,26\%, o que é considerado adequado, porém, o valor de exatidão foi superior ao valor teórico em $51,38 \%$. Já o protocolo da Sigma, subestima os valores de L-Asparaginase, apresentando precisão de 50,99\% e exatidão inferior ao valor teórico em 54,76\%.

Melhores resultados poderiam ter sido encontrados no protocolo da Microplaca, entretanto, a falta de precisão e exatidão da própria técnica de Nesslerização, podem ser considerados fatores cruciais que resultaram em valores fora dos limites estabelecidos, em algumas das análises individuais. $O$ fato de que a reação, após a adição do reagente de Nessler, não apresenta um ponto final e que, a formação de um composto castanho alaranjado após a reação do reagente com a amônia livre, depois de um longo período, pode apresentar-se em solução coloidal e flocular, aumentam as chances de erros analíticos. Somam-se a isso, a formação de um complexo instável durante a reação da amônia livre com o reagente de Nessler, 
além de possíveis erros referentes à falta de experiência do operador (VOGEL, 1981).

Outro ponto a ser destacado é referente à sensibilidade do protocolo da Sigma. Pode-se perceber que, quando obtem-se concentrações pequenas da enzima, o teste da Sigma, por apresentar uma diluição maior da amostra, perde sensibilidade. Além disso, pode-se sugerir que os valores abaixos do ideal, encontrados a partir da utilização do teste Sigma, podem estar relacionados com o tempo de reação. O protocolo Sigma descreve um tempo de reação de 30 minutos, enquanto o padronizado para as outras duas metodologias, foi de 60 minutos.

De acordo com a literatura, o tempo de incubação da reação enzimática para a determinação da atividade de L-Asparaginase é um parâmetro que varia bastante entre os autores. Foram reportados tempos de reação enzimática de 10 minutos (USHA et al., 2011; TIPPANI;SIVADEVUNI, 2012), 15 minutos (NARAYANA; KUMAR;VIJAYALAKSHMI, 2008; SHRIVASTAVA et al., 2012), 30 minutos (RANI; SUNDARAM;VASANTHA, 2012; PRADHAN; DASH;SAHOO, 2013; ZIA et al., 2013) e 60 minutos (THEANTANA; HYDE;LUMYONG, 2007). Diante desses dados, foi realizado um experimento de cinética enzimática a fim de avaliar o tempo de reação ideal para a determinação da atividade da L-Asparaginase (Figuras 6 e 7).

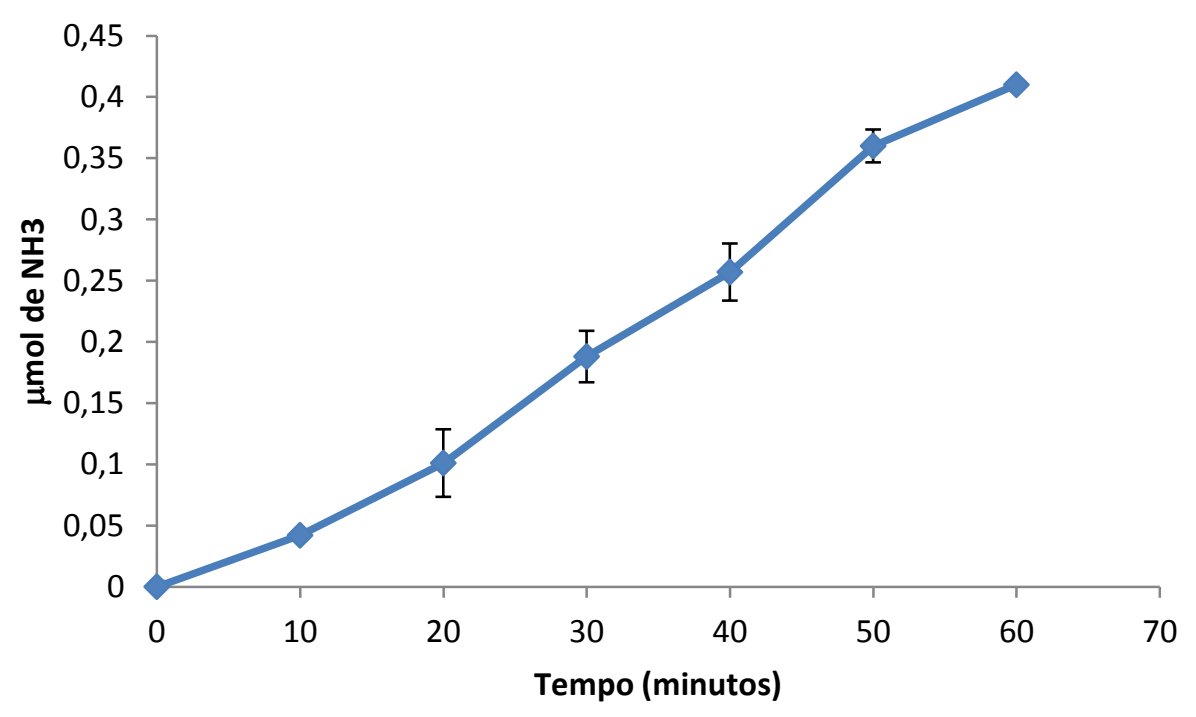

Figura 6 - Cinética enzimática utilizando como amostra uma solução com concentração de $2 U \mathrm{Ul} / \mathrm{mL}$ da enzima purificada (Sigma-Aldrich). 


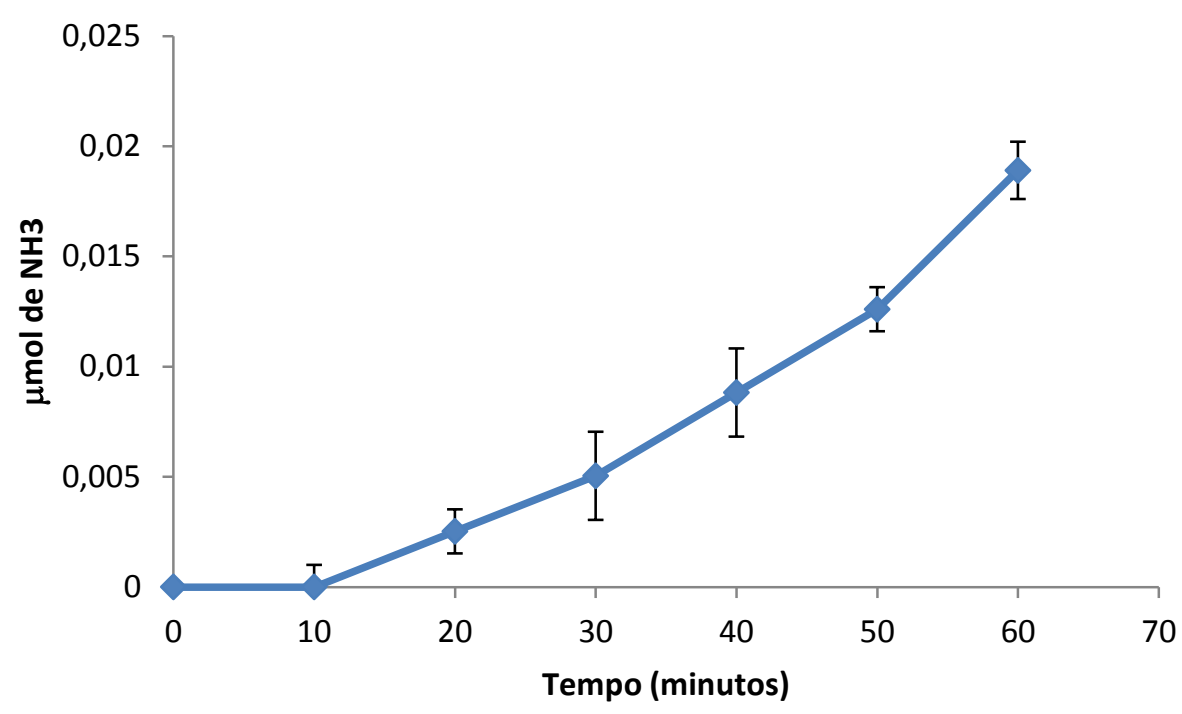

Figura 7 - Cinética enzimática utilizando como amostra a enzima de origem fúngica (filtrado da cultura dialisado), da cepa A. terreus (PC-1.7.A).

Os resultados revelaram que o melhor tempo de reação, dentre os tempos testados, foi de 60 minutos (Figura 6 e 7). Tanto no experimento realizado com a enzima pura $(2 \mathrm{UI} / \mathrm{mL})$, como naquele que utilizou a amostra que continha a enzima de origem fúngica ( $A$. terreus), a quantidade de substrato liberado $\left(\mathrm{NH}_{3}\right)$ foi crescente, atingindo o maior valor no tempo de 60 minutos.

Outra vantagem de grande importância, relacionada ao protocolo realizado em microplaca, é a utilização de pequenas quantidades de reagente, principalmente quando destacamos o emprego do reagente de Nessler, produzido pela reação entre $\mathrm{KI}$ e $\mathrm{Hgl}_{2}$ em solução de $\mathrm{KOH}$, que apresenta toxicidade importante tanto para o pesquisador como para o meio ambiente. $O$ risco ambiental decorrente da geração de resíduos tem aumentado bastante com o progresso tecnológico e, em face disso, há grandes preocupações com os riscos potenciais decorrentes da rotina de indústrias químico-farmacêuticas, bem como de laboratórios de ensino e pesquisa associados (GIL et al., 2007).

O Brasil já conta com uma legislação de controle e descarte de resíduos vigente e rigorosa, porém a falta de fiscalização torna-a, muitas vezes, inexequível. As indústrias estão situadas dentro de um setor mais preocupado com a questão ambiental, devido a grande quantidade de resíduos gerados. Por outro lado, os laboratórios de pesquisas das Universidades brasileiras não são efetivamente fiscalizados e, em grande parte deles, o descarte ainda ocorre de maneira inadequada (GERBASE et al., 2005). 
A determinação da atividade enzimática de L-Asparaginase, em amostras biológicas obtidas a partir de micro-organismos apresenta os mais variados protocolos descritos. Uma diferença importante, ainda no preparo da amostra, são as condições de centrifugação utilizadas após a obtenção do fluido da cultura. Nakahama e colaboradores (1973), em estudo que avaliou a produção de LAsparaginase em diferentes espécies do gênero Fusarium, realizaram o processo de centrifugação utilizando os parâmetros de $8000 \mathrm{~g}$, durante 10 minutos (NAKAHAMA et al., 1973). Outros estudos citam a realização de centrifugações utilizando forças de $6000 \mathrm{~g}$ e $9000 \mathrm{~g}$, durante 10 minutos, a temperatura de $4{ }^{\circ} \mathrm{C}$ (KUMAR et al., 2013; ZIA et al., 2013). Akilandeswari e colaboradores (2012) citam parâmetros ainda mais variados: $2000-3000 \mathrm{rpm}$, durante 15 minutos (AKILANDESWARI; KAVITHA;VIJAYALAKSHMI, 2012). Diante desses dados, diferentes metodologias de centrifugação foram realizadas antes da quantificação da atividade enzimática. Amostras de um segundo cultivo de A. terreus (PC-1.7.A) foram preparadas e a atividade enzimática foi quantificada (Figura 8).

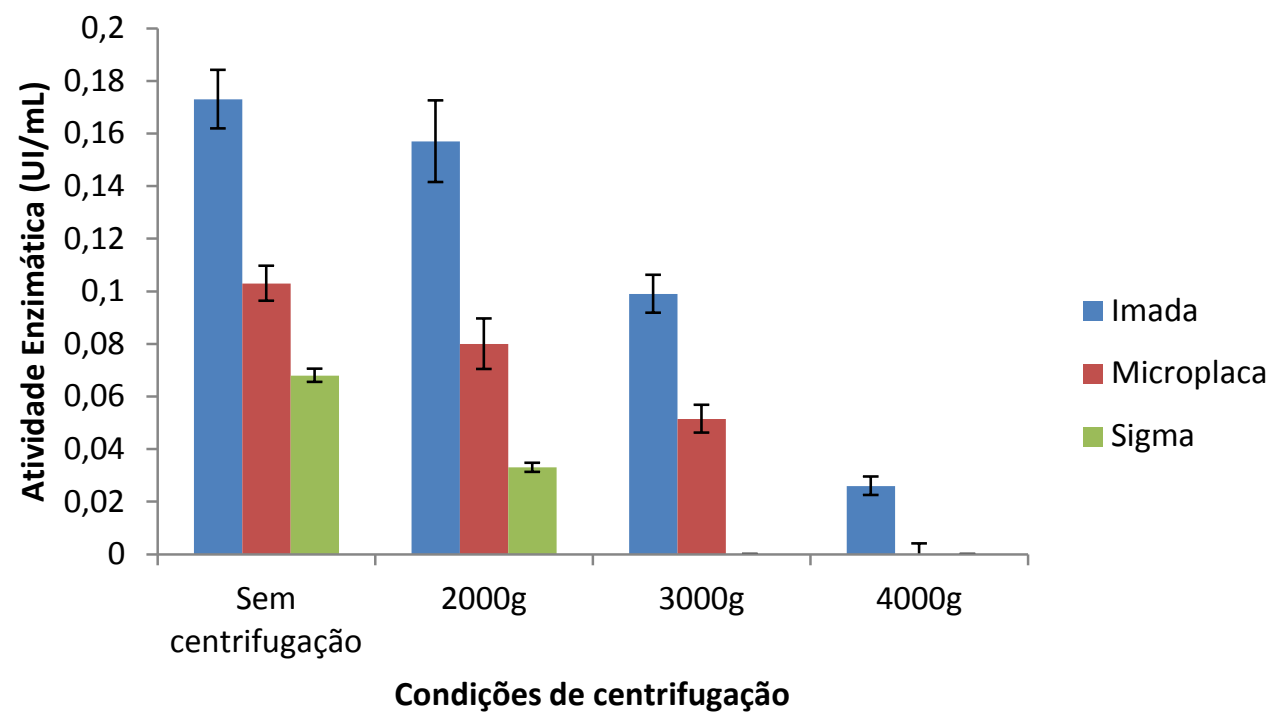

Figura 8 - Valores de atividade enzimática obtidos a partir de amostras dialisadas, de um único cultivo de $A$. terreus (PC-1.7.A), expostas a diferentes parâmetros de centrifugação. Todas as centrifugações foram realizadas durante 5 minutos.

Os resultados obtidos corroboram com a maioria dos trabalhos encontrados, sugerindo que este processo é inadequado para a preservação da atividade enzimática da L-Asparaginase. Trabalhos realizados por diversos autores não utilizam deste processo para a obtenção da enzima microbiana, sendo relatado 
apenas a realização da filtração à vácuo (LOUREIRO, 2010; GURUNATHAN;SAHADEVAN, 2012; SHRIVASTAVA et al., 2012; SARQUIS et al., 2004). Gulati e colaboradores (1997), utilizaram da técnica de centrifugação apenas para as culturas bacterianas, nas condições de $6000 \mathrm{rpm}$, durante 15 minutos (GULATI; SAXENA;GUPTA, 1997).

Outro parâmetro importante na determinação da atividade enzimática é a quantidade de substrato utilizado durante a reação. Diferentes concentrações de LAsparagina são utilizadas em protocolos de determinação da atividade de LAsparaginase, variando de 0,003 M (TIPPANI;SIVADEVUNI, 2012) até 0,02 M (THEANTANA; HYDE;LUMYONG, 2007). Assim, foram preparadas soluções contendo L-Asparagina em diferentes concentrações e a determinação da atividade enzimática foi avaliada em solução de concentração conhecida $(1 \mathrm{Ul} / \mathrm{mL})$ da enzima purificada (Sigma-Aldrich), assim como em amostras do caldo de cultura filtrado e dialisado de A. terreus (PC-1.7.A). Esse experimento foi conduzido a partir da utilização do protocolo da Microplaca.

Nos resultados obtidos com a enzima pura, a concentração de $0,16 \mathrm{M}$ de substrato pareceu exercer uma pequena inibição frente a atividade enzimática (Figura 9). Quando foram utilizadas as amostras obtidas a partir de cultivos fúngicos, a melhor concentração de substrato a ser utilizada na reação parece ser a de 0,04 M (concentração final na reação de $0,026 \mathrm{M}$ ), entretanto, não houve diferença significativa entre os valores de atividade enzimática encontrados (Figura 10). 


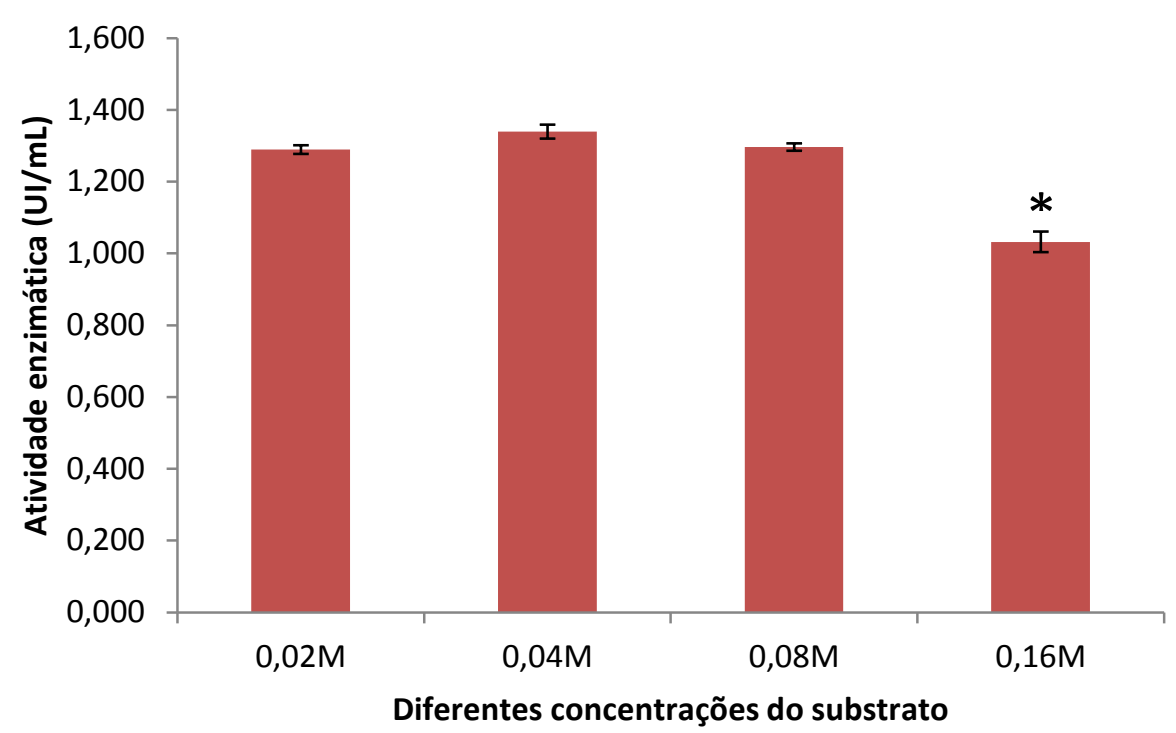

Figura 9 - Valores de atividade enzimática obtidos a partir de solução de concentração conhecida da enzima L-Asparaginase purificada (Sigma-Aldrich), utilizando diferentes concentrações de substrato durante a reação. * nível de significancia igual a 95\%.

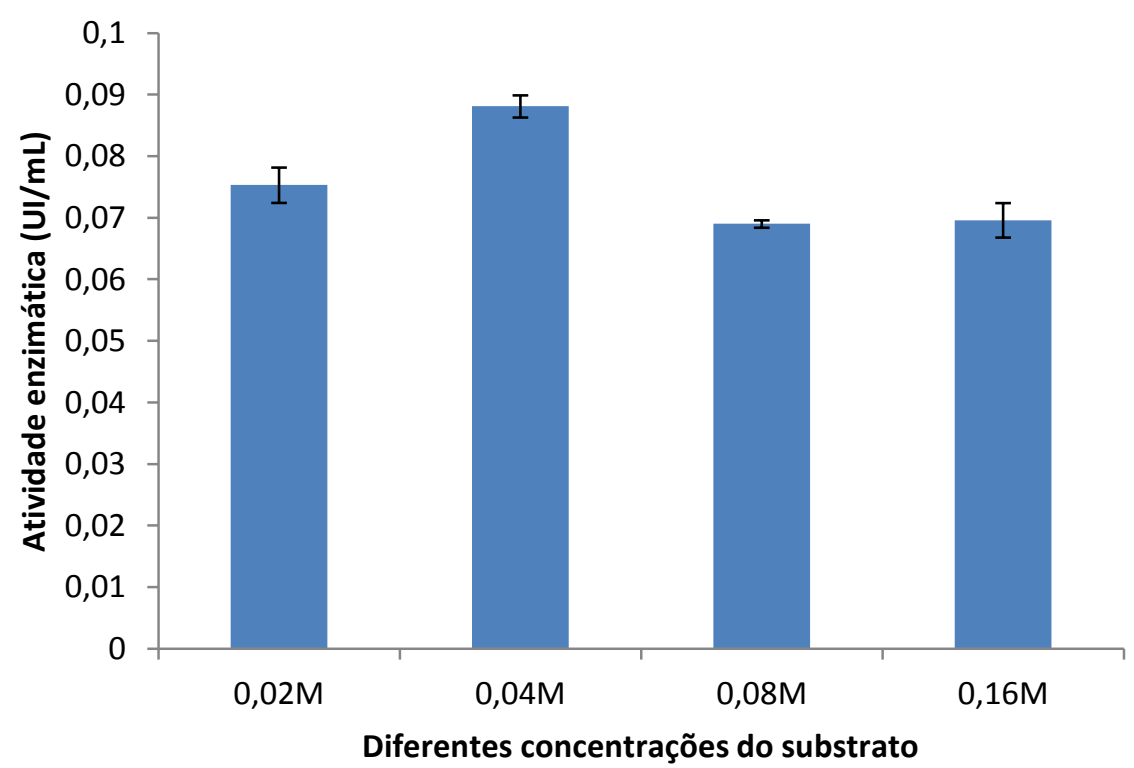

Figura 10 - Valores de atividade enzimática, de amostra de cultivo de $A$. terreus (PC-1.7.A), utilizando diferentes concentrações de substrato durante a reação.

A diminuição dos valores de atividade enzimática, observada durante a utilização da maior concentração de substrato testada (Figura 9), pode ser explicada como uma possível inibição da atividade da L-Asparaginase ocasionada a partir da utilização de uma concentração maior de L-Asparagina durante a reação.

Os valores de linearidade, precisão e exatidão encontrados para a metodologia da Microplaca encontram-se dentro dos limites oficiais. Além disso, o 
teste utiliza pouca quantidade de reagente quando comparado a outros testes encontrados na literatura, ponto importante para o controle de resíduos produzidos dentro de laboratórios de pesquisa e de indústrias farmacêuticas. A retirada do interferente (amônia proveniente do processo fermentativo) das amostras só foi eficiente a partir da realização da diálise, que se mostrou indispensável para a correta quantificação da produção enzimática.

\subsection{PADRONIZAÇÃO DO PROCESSO DE PRODUÇÃO DE L-ASPARAGINASE EM MEIO LÍQUIDO}

A padronização do processo de produção de L-Asparaginase foi realizada com o objetivo de predizer quais serão as condições de produção a serem utilizadas nas diferentes espécies que apresentaram halo positivo no cultivo em meio sólido. Vale ressaltar que, as condições adotadas aqui serão utilizadas apenas com o objetivo de triagem inicial de produtores em meio líquido. A produção da enzima LAsparaginase naqueles fungos que apresentarem maiores valores de atividade foi otimizada no último capítulo deste trabalho.

A maioria dos trabalhos utilizam o aminoácido L-Asparagina na composição dos meios líquidos de cultivo para a produção de L-Asparaginase (RANI; SUNDARAM;VASANTHA, 2012; SHRIVASTAVA et al., 2012; ZIA et al., 2013). Entretanto, muitos vem substituindo esse aminoácido pela L-Prolina e estão obtendo bons resultados (AKILANDESWARI; KAVITHA;VIJAYALAKSHMI, 2012; TIPPANI;SIVADEVUNI, 2012; PATRO et al., 2014; SARQUIS et al., 2004). Assim, foram avaliados alguns parâmetros frente a dois cultivos diferentes da cepa $A$. terreus (PC-1.7.A), um utilizando L-Asparagina e outro L-Prolina, como componentes do meio líquido de cultivo.

Foram realizadas curvas de crescimento de sete dias, a partir dos dois cultivos de A. terreus (PC-1.7.A) e, ao final de cada dia de cultivo, as amostras foram separadas do micélio através de filtração com papel filtro Whatman $n^{\circ} 1.0$ caldo filtrado foi dialisado durante vinte e quatro horas e armazenado sob refrigeração para análises posteriores. $O$ micélio fúngico retido foi utilizado para as análises de crescimento fúngico (medida de biomassa). Alguns parâmetros como medidas de biomassa, proteína total, $\mathrm{pH}$ final do meio e atividade enzimática foram avaliados. 


\subsubsection{Medidas de biomassa}

O resultado obtido a partir das medidas de biomassa encontradas demonstra que houve melhor crescimento no meio que continha a L-Prolina em sua composição. Além disso, os dois cultivos parecem possuir o mesmo padrão, ou seja, crescimento fúngico crescente até o quinto dia e queda brusca no sexto dia (Figura 11).

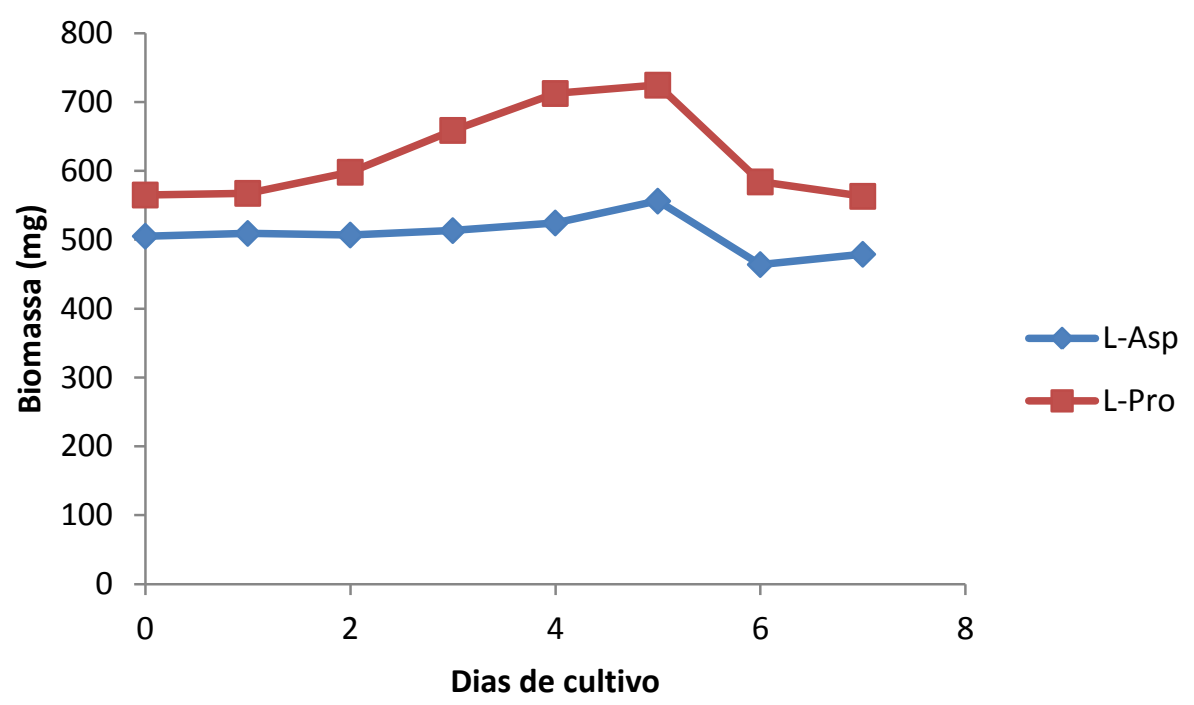

Figura 11 - Crescimento da cepa fúngica durante sete dias, em dois meios líquidos de cultivo. A linha vermelha representa o crescimento em meio composto por glicose, L-Prolina e sais, enquanto a linha azul representa um meio que utilizou L-Asparagina, em substituição a L-Prolina, mais glicose e sais.

\subsubsection{Valores de $\mathrm{pH}$ final dos meios de cultivo}

Segundo Colen (2006), o metabolismo do fungo, durante o crescimento, altera o pH do meio de cultivo, seja pela absorção de ânions ou cátions ou pela produção de ácidos orgânicos ou amônia (COLEN, 2006). Avaliando estas possíveis alterações de $\mathrm{pH}$ ocasionadas durante o processo fermentativo, a Figura 12 reporta os resultados encontrados ao final de cada dia de cultivo. Vale ressaltar que essa verificação foi realizada após a filtração para separação do micélio e do caldo fermentado e antes da realização do processo de diálise. 


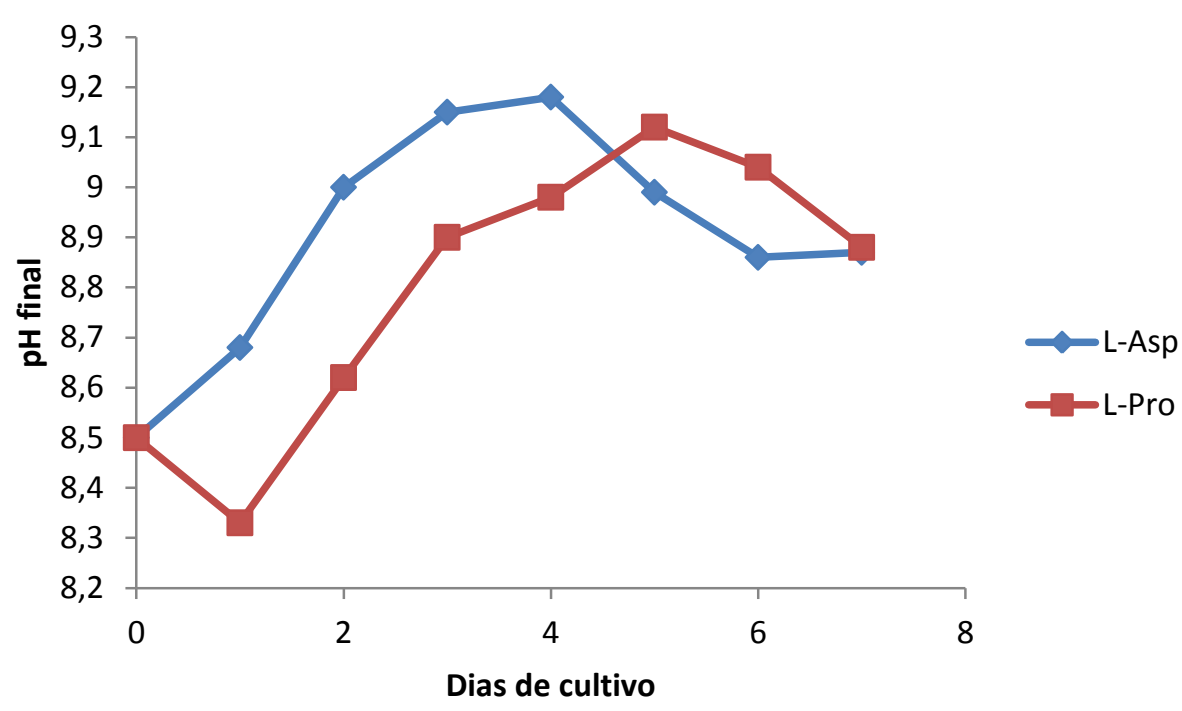

Figura 12 - Valores de $\mathrm{pH}$ final dos meios de cultivo, obtidos durante os sete dias da curva de crescimento. A linha vermelha representa o cultivo em meio composto por glicose, L-Prolina e sais, enquanto a linha azul representa um meio que utilizou L-Asparagina em substituição a L-Prolina.

Os resultados obtidos nos dois meios de cultivo são muito semelhantes e, apesar de discreto, os valores de $\mathrm{pH}$ apresentaram-se aumentados, quando comparados ao $\mathrm{pH}$ inicial do meio $(8,5)$. Os maiores valores obtidos foram de 9,12 e 9,18 para os cultivos contendo, respectivamente, L-Prolina (quinto dia) e LAsparagina (quarto dia). Uma vez que, a L-Asparaginase, uma amino hidrolase, catalisa a hidrólise do aminoácido L-Asparagina, formando ácido aspártico e amônia (DHARMSTHITI;LUECHAI, 2011; EBRAHIMINEZHAD; RASOUL-AMINI;GHASEMI, 2011; NOMME et al., 2012), o aumento do pH do meio de cultura pode estar relacionado com a liberação de amônia (GULATI; SAXENA;GUPTA, 1997; DHALE;MOHAN-KUMARI, 2014).

Em estudo realizado por De Jong (1972), foi destacada uma possível correlação do aumento do $\mathrm{pH}$ final do meio de cultivo, com a produção enzimática de L-Asparaginase, o que pode ser constatado também por Gulati e colaboradores (1997), em trabalho que descreveu uma metodologia para a realização de triagem de micro-organismos produtores de L-Asparaginase (DEJONG, 1972; GULATI; SAXENA;GUPTA, 1997). 


\subsubsection{Proteína total}

Os resultados encontrados foram favoráveis à utilização do meio com LProlina, quando comparado aquele que apresenta L-Asparagina na sua composição. Pode-se perceber, a partir da Figura 13, que os valores de proteínas totais obtidos a partir do cultivo com L-Prolina foram bem superiores, quando comparados ao cultivo com L-Asparagina, a partir do quinto dia de cultivo.

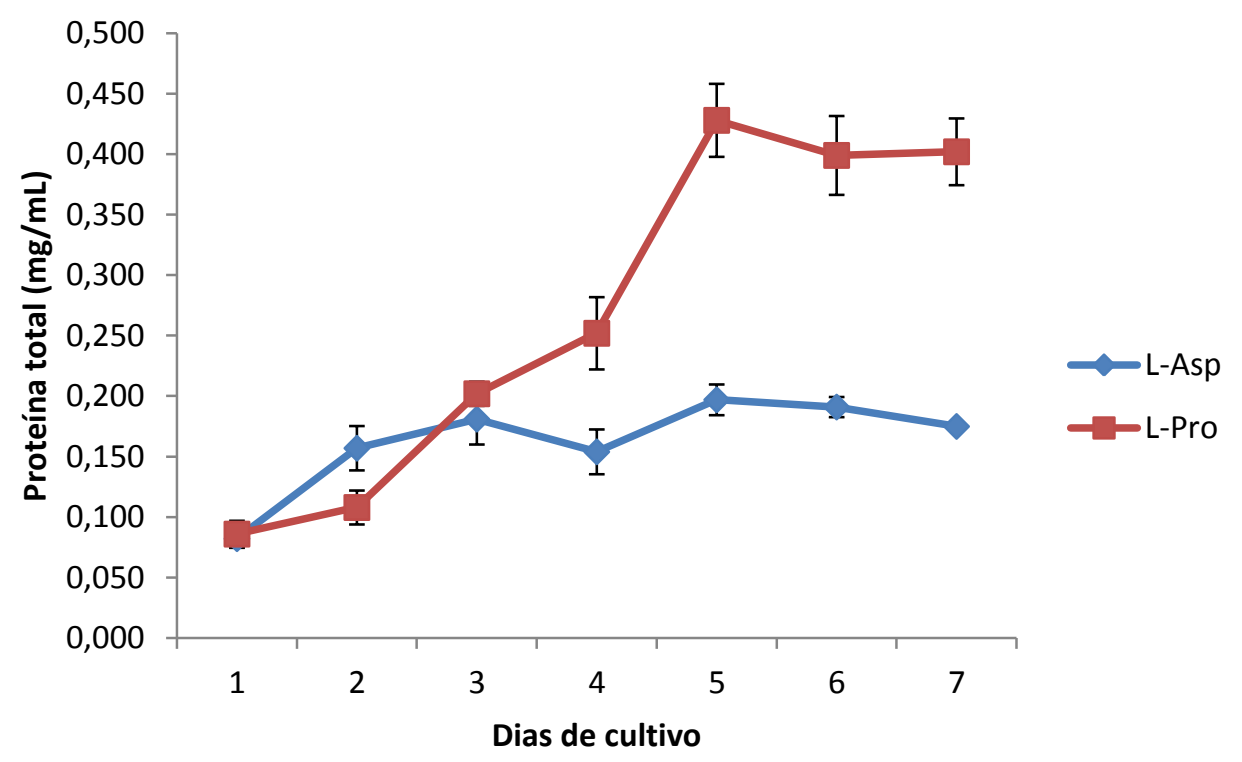

Figura 13 - Valores de proteína total produzida durante os sete dias de cultivo. A linha vermelha representa o cultivo em meio composto por glicose, L-Prolina e sais, enquanto a linha azul representa um meio que utilizou L-Asparagina em substituição a L-Prolina.

\subsubsection{Atividade enzimática}

Os resultados apontam que a utilização do aminoácido L-Prolina na composição dos meios líquidos de cultivo, quando comparado à L-Asparagina, é mais favorável à produção enzimática. Os valores máximos de atividade foram encontrados em dias diferentes quando se comparam os dois meios utilizados. $O$ meio que continha L-Prolina em sua composição apresentou valor máximo de atividade enzimática no quinto dia de cultivo $(0,0974 \mathrm{UI} / \mathrm{mL})$, enquanto que, para o meio que leva L-Asparagina, o valor máximo ocorreu no quarto dia $(0,0488 \mathrm{UI} / \mathrm{mL})$ (Figura 14). 


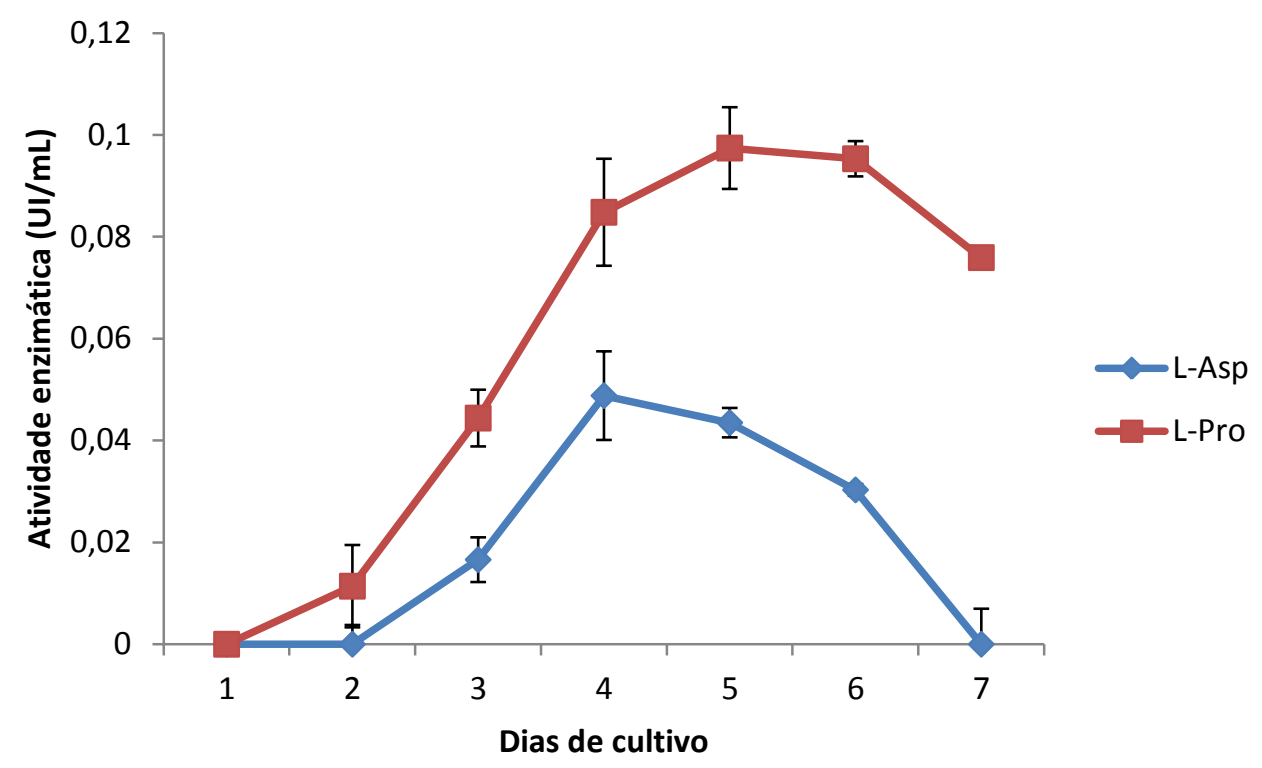

Figura 14 - Valores de atividade enzimática de L-asparaginase, durante os sete dias de cultivo. A linha vermelha representa o cultivo em meio composto por glicose, L-Prolina e sais, enquanto a linha azul representa um meio que utilizou L-Asparagina em substituição a L-Prolina.

De acordo com a literatura, diferentes tempos de incubação são utilizados para a produção de L-Asparaginase por fungos. A grande maioria dos trabalhos utiliza e também demonstra que, em 96 horas de incubação foram encontrados os melhores valores de atividade enzimática (RANI; SUNDARAM;VASANTHA, 2012; SHRIVASTAVA et al., 2012; ZIA et al., 2013). Por outro lado, alguns estudos demonstram outros tempos ótimos para a produção desta enzima.

Dados que divergem dos encontrados neste estudo foram relatados em dois trabalhos que utilizaram cepas de $A$. terreus, onde os níveis mais altos de produção enzimática foram encontrados em 48 e 58 horas de cultivo (GURUNATHAN;SAHADEVAN, 2012; SARQUIS et al., 2004). Tippani e colaboradores (2012), em trabalho que avaliou o efeito de fatores nutricionais na produção de L-Asparaginase por diferentes espécies de Fusarium, utilizaram um período de incubação de 16 dias, em meio de cultura líquido (TIPPANI;SIVADEVUNI, 2012). Diferentemente dos trabalhos acima citados, é relevante destacar a existência de estudo que, embora não descreva qual foi a metodologia utilizada para a determinação da atividade da L-Asparaginase, utilizou a cepa Aspergillus flavus e demonstrou que o período com maior produção enzimática permaneceu em torno do $10^{\circ}$ e $12^{\circ}$ dia de incubação (PATRO et al., 2014). 
Diante de todos os resultados obtidos a partir da comparação de cultivos utilizando, em sua composição, L-Asparagina ou L-Prolina, verificou-se um maior crescimento fúngico, maior produção de proteínas totais e maior atividade enzimática de L-Asparaginase no meio contendo o aminoácido L-Prolina. Frente a estes dados, optou-se por adotar a L-Prolina, ao invés da L-Asparagina, na composição do meio de cultivo padrão a ser utilizado com todas as cepas que apresentarem halo positivo no teste de triagem.

$\mathrm{O}$ teste que avaliou as medidas de $\mathrm{pH}$ final dos dois meios de cultivo apresentou valores bem similares, porém, quando relacionados com os valores de atividade de L-Asparaginase, é possível concluir que o aumento do $\mathrm{pH}$ do meio pode não estar relacionado apenas a produção de amônia pela ação da L-Asparaginase. Nos últimos anos, um grande progresso foi feito na descoberta de diferentes rotas metabólicas e vias de sinalização que relacionam o desenvolvimento dos fungos com a biossíntese de muitos produtos naturais. No entanto, ainda há muito a ser compreendido. A complexidade destas redes reguladoras, com vários locais-alvo e interligações com outros mecanismos de regulação, torna a sua completa elucidação uma tarefa desafiadora (CALVO et al., 2002).

Quanto ao período de incubação, corroborando com a grande maioria dos trabalhos disponíveis, os maiores níveis de atividade enzimática foram encontrados entre $\circ 4^{\circ}$ e $\circ 6^{\circ}$ dias de cultivo. Assim, optou-se pela utilização de períodos de 5 dias de incubação, durante os cultivos em meio líquido, para todas as cepas testadas.

\subsection{ISOLAMENTO E IDENTIFICAÇÃO DOS FUNGOS FILAMENTOSOS}

\subsubsection{Fungos endofíticos}

Folhas de cinco espécies vegetais características do bioma Cerrado da região Centro-Oeste brasileira foram utilizadas para 0 isolamento de espécies fúngicas endofíticas. A Tabela 11 e a Figura 15 destacam as cinco espécies utilizadas, incluindo imagens das mesmas, além da quantidade de isolados obtidos de cada uma delas. 

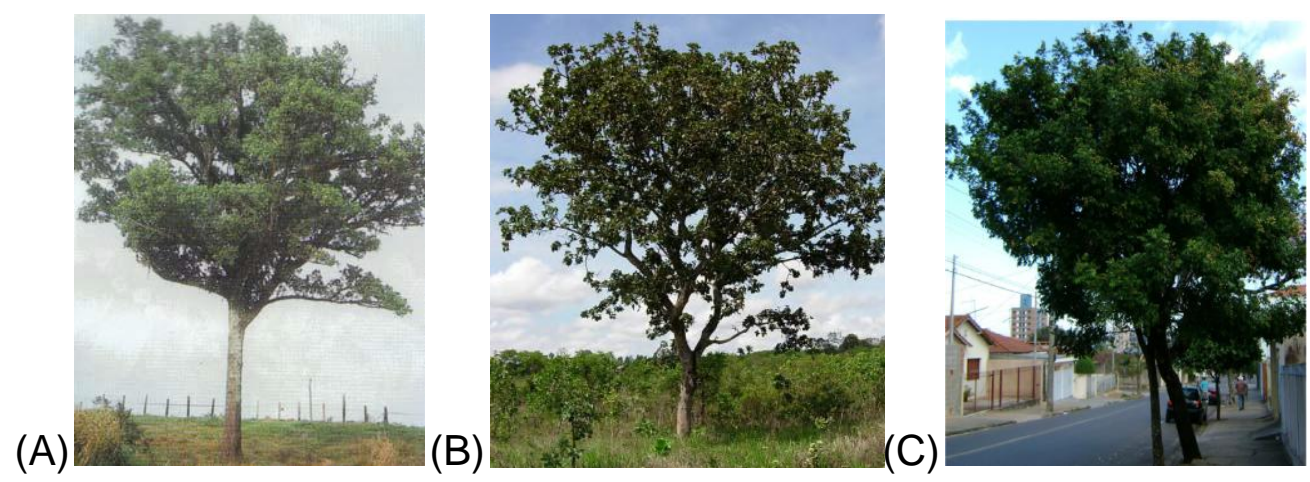

(D)
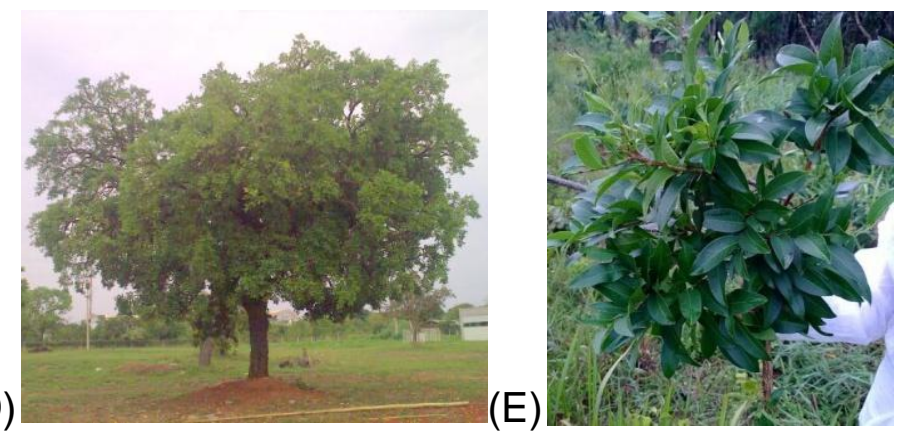

Figura 15 - Imagens das espécies vegetais utilizadas para o isolamento de fungos endofíticos. (A) Calophyllum brasiliensis; (B) Eriotheca pubescens; (C) Sapindus saponaria; (D) Eugenia dysenterica; (E) Erythroxylum daphnites (NERY, 2006; BARBOSA, 2008; GRISI, 2010; SILVA, 2013).

Tabela 11 - Espécies vegetais utilizadas para o isolamento de fungos endofíticos.

\begin{tabular}{cc}
\hline Espécie vegetal & $\begin{array}{c}\text { № total de } \\
\text { isolados }\end{array}$ \\
\hline Calophyllum brasiliensis & 2 \\
Eugenia dysenterica & 5 \\
Erythroxylum daphnites & 3 \\
Eriotheca pubescens & 4 \\
Sapindus saponaria & 3 \\
\hline
\end{tabular}

Foram isolados um total de dezessete fungos endofíticos e todos foram encaminhados para identificação. A Figura 16 ilustra, resumidamente, algumas etapas no isolamento de uma cepa fúngica a partir da espécie vegetal Erythroxylum daphnites. 
(A)

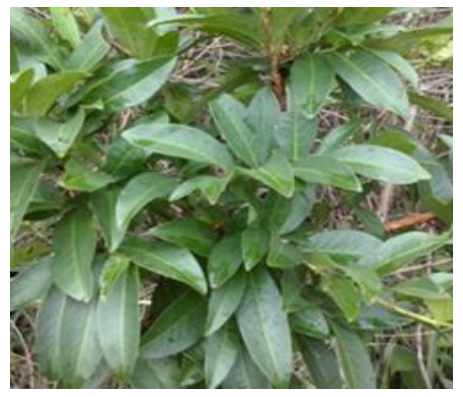

(B)

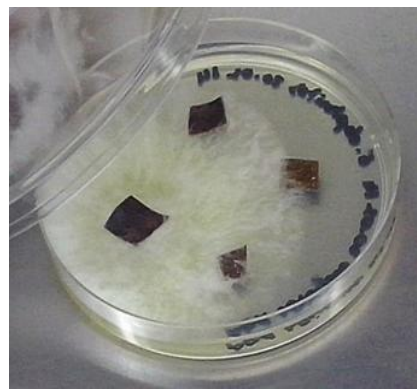

(C)

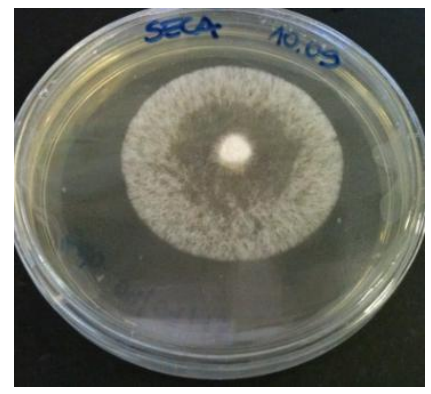

Figura 16 - Etapas do isolamento de fungos endofíticos. (A) Folhas da espécie vegetal Erythroxylum daphnites; (B) Material vegetal aplicado em placas de petri contendo o meio de cultura dextrose Sabouraud, onde já é possível a visualização de crescimento fúngico; (C) O fungo endofítico isolado.

\subsubsection{Fungos isolados do solo}

O isolamento de cepas fúngicas a partir de amostras de solo do bioma Cerrado da região Centro-Oeste brasileira foi realizado pela equipe de pesquisa do Instituto de Biologia da Universidade de Brasília, coordenada pelo Professor Edivaldo Ximenes Ferreira Filho, responsável pelo Laboratório de Enzimologia e colaborador desse projeto. Um total de vinte e cinco cepas, de diferentes espécies, foram gentilmente cedidas para este estudo (Tabela 12).

Tabela 12 - Fungos filamentosos isolados de diferentes regiões do solo do bioma Cerrado da região Centro-Oeste brasileira, utilizados neste trabalho.

\begin{tabular}{cc}
\hline \multicolumn{2}{c}{ Espécies } \\
\hline Aspergillus flavus & Penicillium crustosum \\
Aspergillus foetidus & Penicillium decumbens \\
Aspergillus sydowii & Penicillium felutanum \\
Aspergillus terreus & Penicillium funiculosum \\
Aspergillus versicolor & Penicillium glandicola \\
Fusarium sp. & Penicillium restrictum \\
Fusarium oxysporum & Penicillium rugulosum \\
Fusarium semitectum & Penicilium roqueforti \\
Fusarium solani & Penicillium variabile \\
Mucor sp. & Phaecilomyces lilacinus \\
Penicillium aurantiogriseum & Phaecilomyces variotti \\
Penicillium citrino & Trichoderma sp. \\
Penicillium corylophilum & \\
\hline
\end{tabular}




\subsection{SELEÇÃO DE FUNGOS QUANTO À PRODUÇÃO DE L-ASPARAGINASE EM MEIO SÓLIDO}

O screening realizado a partir do teste do halo, em ágar CDM, acrescido de vermelho de fenol, revelou que das quarenta e duas cepas isoladas, vinte e duas apresentaram halo vermelho ao redor da colônia (Tabela 13). O surgimento do halo ocorre devido a presença do vermelho de fenol na composição do meio sólido utilizado no teste. $\mathrm{O}$ vermelho de fenol é um indicador de $\mathrm{pH}$ que muda de uma coloração amarela em condições ácidas, para vermelha em condições básicas/alcalinas (Figura 17). A zona avermelhada que surge ao redor da colônia fúngica indica alteração do $\mathrm{pH}$, que pode ter sido ocasionada a partir do acúmulo de amônia no meio (GULATI; SAXENA;GUPTA, 1997; THEANTANA; HYDE;LUMYONG, 2007).

(A)

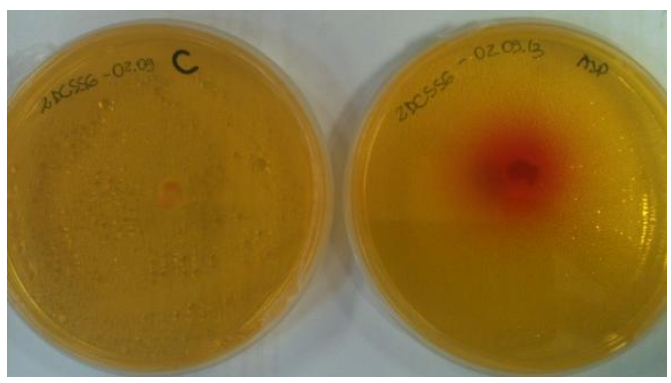

(C)

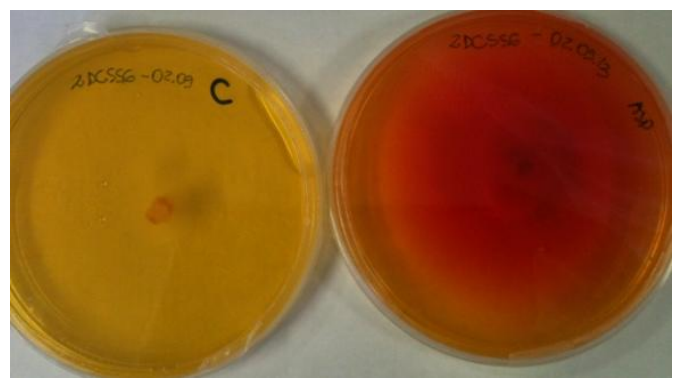

(B)

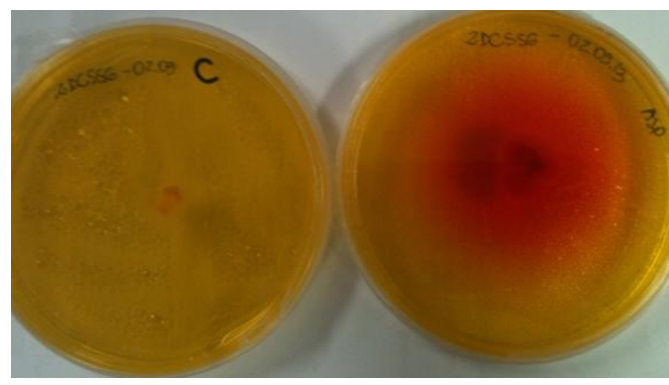

(D)

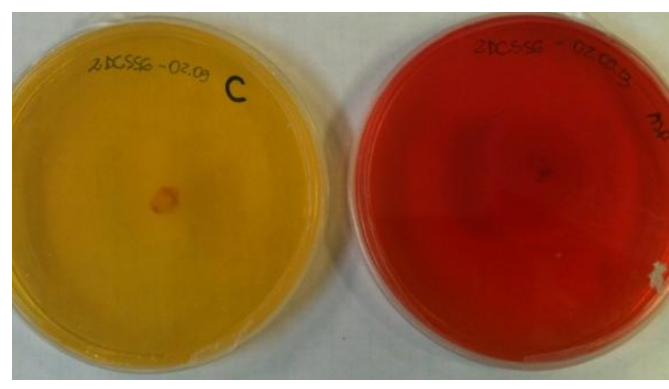

Figura 17 - Formação de halo vermelho ao redor da colônia indicando a possível produção de LAsparaginase pela espécie fúngica. Todas as figuras apresentam uma placa controle (esquerda) e uma placa teste (direita). (A) 24 horas de incubação; (B) 48 horas de incubação; (C) 72 horas de incubação; (D) 96 horas de incubação.

Neste teste, foram preparadas e semeadas placas controle que não continham em sua formulação o aminoácido L-Asparagina. Desta maneira, pode-se sugerir que o aparecimento do halo apenas na placa teste, é um forte indício de que o aumento do $\mathrm{pH}$ do meio é devido a quebra da L-Asparagina pela enzima LAsparaginase (GULATI; SAXENA;GUPTA, 1997; HOLKER; HOFER;LENZ, 2004; THEANTANA; HYDE;LUMYONG, 2007). 
Tabela 13 - Vinte e dois isolados fúngicos que exibiram zona avermelhada em torno de colônias.

\begin{tabular}{ccc}
\hline Identificação & Espécie & $\begin{array}{c}\text { Formação do halo } \\
\text { ao redor da colônia* }\end{array}$ \\
\hline RCFS 14 & Aspergillus flavus & ++ \\
DCFS 9 & Aspergillus sydowii & +++ \\
2DCSS6 & Aspergillus terreus & +++ \\
DCFS 1 & Aspergillus versicolor & ++ \\
DCFS 10 & Fusarium sp. & ++ \\
2DSST1 & Fusarium oxysporum & ++ \\
ACFS 16 & Fusarium semitectum & +++ \\
FEC2 & Guignardia mangiferae & +++ \\
DCFT P7 & Mucor sp. & + \\
2DSST10 & Penicillium aurantiogriseum & ++ \\
RCFS 24 & Penicillium citrinum & +++ \\
2DMGSE2 & Penicillium corylophilum & ++ \\
DCFF 2 & Penicillium crustosum & ++ \\
DCFS 6 & Penicillium decumbens & +++ \\
RCFS 6 & Penicillium felutanum & +++ \\
2DSSSE1 & Penicillium funiculosum & +++ \\
DCFF 4 & Penicillium glandicola & ++ \\
RCFT 14 & Penicillium restrictum & ++ \\
2RCSS1 & Penicillium variable & ++ \\
RCFS 16 & Phaecilomyces lilacinus & ++ \\
RCFS 21 & Trichoderma sp. & ++ \\
FB2 & NI & ++ \\
\hline${ }^{*}$ halo pequeno (+); médio (++); grande (+++). & \\
${ }^{*}$ Não identificado. & &
\end{tabular}

Gulati e colaboradores (1997), Rani e colaboradores (2012) e Thirunavukkarasu e colaboradores (2011), durante a realização do teste do halo, utilizando o indicador de $\mathrm{pH}$ vermelho de fenol, também verificaram a ocorrência de halo vermelho ao redor da colônia de diferentes espécies de Aspergillus, Penicillium e Fusarium (GULATI; SAXENA;GUPTA, 1997; THIRUNAVUKKARASU et al., 2011; RANI; SUNDARAM;VASANTHA, 2012). Em outro trabalho, diversas espécies de fungos endofíticos também exibiram grandes diâmetros de zona vermelha, quando comparados ao diâmetro da colônia (THEANTANA; HYDE;LUMYONG, 2007).

Das cepas fúngicas que apresentaram halo vermelho ao redor da colônia, foram encontrados genes descritos para a produção da enzima L-Asparaginase apenas para as espécies Aspergillus terreus e Aspergillus flavus. Essa informação 
foi obtida após pesquisa realizada no banco de dados do National Center for Biotechnology Information (NCBI). Vale ressaltar que, não foram obtidas informações sobre o genoma de nove dentre as espécies pesquisadas.

A formação do halo avermelhado está, provavelmente, relacionada ao aumento do $\mathrm{pH}$ do meio devido a degradação do substrato L-Asparagina e consequente liberação de amônia. No entanto, não é possível afirmar que este aumento do $\mathrm{pH}$ do meio tenha ocorrido devido a produção de L-Asparaginase pelos fungos inoculados. Outros metobólitos fúngicos podem ser responsáveis pela elevação do $\mathrm{pH}$ do meio e, consequentemente, pelo aparecimento do halo vermelho ao redor da colônia.

\subsection{SELEÇÃO DE FUNGOS QUANTO À PRODUÇÃO DE L-ASPARAGINASE EM MEIO LÍQUIDO}

A partir do resultado do screnning, as vinte e duas cepas fúngicas que apresentaram formação de halo vermelho ao redor da colônia foram submetidas a um cultivo em meio líquido. O período de incubação foi de três dias no pré-inóculo e mais cinco dias no meio fermentativo, totalizando oito dias de incubação. No oitavo dia, o extrato bruto foi separado do micélio fúngico através de filtração e, em seguida, dialisado durante vinte e quatro horas a $4^{\circ} \mathrm{C}$

Após a diálise, as amostras foram submetidas à análise da atividade enzimática pelo método da Microplaca e, como resultado, dez fungos foram capazes de produzir a enzima L-Asparaginase. As atividades enzimáticas encontradas variaram entre 0,019 e $0,610 \mathrm{Ul} / \mathrm{mL}$ (Tabela 14). Os isolados FEC2, DCFS9, FB2 foram os que exibiram maiores níveis de atividade: 0,610, 0,131 e 0,0982 Ul/mL, respectivamente. Alguns autores relatam produção de L-Asparaginase fúngica com níveis muito semelhantes aos encontrados neste trabalho (THEANTANA; HYDE;LUMYONG, 2007; IMADA et al., 1973; SARQUIS et al., 2004). 
Tabela 14 - Produção enzimática de L-Asparaginase, em meio líquido, encontrada em dez dos vinte e dois isolados fúngicos testados.

\begin{tabular}{cccc}
\hline Identificação & Espécie & Origem & $\begin{array}{c}\text { Atividade } \\
\text { enzimática } \\
\text { (UI/mL) }\end{array}$ \\
\hline FEC2 & Guignardia mangiferae & $\begin{array}{c}\text { Eugenia dysenterica } \\
\text { Amostra solo }\end{array}$ & 0,610 \\
DCFS 9 & Aspergillus sydowii & NI & 0,131 \\
FB2 & Eugenia dysenterica & 0,098 \\
DCFF 2 & Penicillium crustosum & Amostra solo & 0,094 \\
2DCSS6 & Aspergillus terreus & Amostra solo & 0,089 \\
DCFS 6 & Penicillium decumbens & Amostra solo & 0,079 \\
DCFF 4 & Penicillium glandicola & Amostra solo & 0,073 \\
DCFS 1 & Aspergillus versicolor & Amostra solo & 0,054 \\
2DSST10 & Penicillium aurantiogriseum & Amostra solo & 0,040 \\
DCFS 10 & Fusarium sp. & Amostra solo & 0,019 \\
\hline
\end{tabular}

${ }^{*}$ Não identificado

Theantana e colaboradores (2007) analisaram diferentes cepas fúngicas endofíticas e os níveis de produção da enzima L-Asparaginase variaram entre 0,014 e $1,530 \mathrm{UI} / \mathrm{mL}$ (THEANTANA; HYDE;LUMYONG, 2007). Os resultados deste trabalho foram semelhantes àqueles relatados por Sarquis e colaboradores (2004), onde a cepa de $A$. terreus apresentou valores de atividade de L-Asparaginase, em meio líquido, de 58,8 UI/L (SARQUIS et al., 2004). Loureiro (2010) também utilizou uma cepa da espécie $A$. terreus para produzir L-Asparaginase e obteve um resultado de $0,254 \mathrm{Ul} / \mathrm{mL}$, entretanto, vale ressaltar que, a metodologia para determinação da atividade enzimática, neste estudo, não utilizou a técnica de Nesslerização (LOUREIRO, 2010).

Nakahama e colaboradores (1973) demonstraram que várias espécies de Fusarium foram capazes de produzir L-Asparaginase. Apenas três, das cinquenta estirpes de Fusarium testadas não produziram L-Asparaginase com níveis maiores que $0,1 \mathrm{Ul} / \mathrm{mL}$ (NAKAHAMA et al., 1973). Estudo publicado por Imada e colaboradores (1973) testaram diferentes espécies de Fusarium e Penicillium visando a produção de L-Asparaginase e, como resultado, os níveis de produção variaram entre $0,10 \mathrm{UI} / \mathrm{mL}$ com $F$. roseum a 1,32 UI/mL com Penicillium urticae. Para as espécies $P$. expansum e $P$. grabulatum, os valores foram de $0,83 \mathrm{Ul} / \mathrm{ml}$ e $0,44 \mathrm{Ul} / \mathrm{mL}$, respectivamente. Quanto as espécies de Fusarium, todas apresentaram valores positivos de produção (IMADA et al., 1973). 
Alguns trabalhos relatam valores acima dos encontrados neste trabalho. Igarasi e colaboradores (1974) relatam atividade da L-Asparaginase obtida a partir da espécie Fusarium oxysporum, com valores de $2,5 \mathrm{UI} / \mathrm{mL}$ (IGARASI et al., 1974). Zia e colaboradores (2013) reportaram produção de L-Asparaginase a partir de Aspergillus niger, com valores máximos de $5,40 \mathrm{UI} / \mathrm{mL}$ (ZIA et al., 2013). Outros estudos recentes também revelaram produções enzimática acima daquelas encontradas neste trabalho, a partir das espécies Penicillium digitatum e Aspergillus flavus (SHRIVASTAVA et al., 2012; PATRO et al., 2014). O trabalho que utilizou a cepa de A. flavus, inclusive, não descreve a metodologia utilizada para a determinação da atividade da enzima (PATRO et al., 2014).

Os resultados encontrados por Patro e colaboradores (2014) são dados que divergem dos que foram encontrados neste estudo. A atividade enzimática de Aspergillus flavus chegou ao valor máximo de $42,3 \mathrm{UI} / \mathrm{mg}$ de proteína (PATRO et al., 2014). Gurunathan e colaboradores (2012) utilizaram a espécie Aspergillus terreus para a produção de L-Asparaginase e obtiveram o valor de 40,97 Ul/ml como atividade máxima da enzima (GURUNATHAN;SAHADEVAN, 2012). Diferenças na produção de metabólitos a partir de fungos de uma mesma espécie podem estar relacionadas às adaptações que ocorrem entre o micro-organismo e seu habitat (ESPOSITO;AZEVEDO, 2010).

Ao estudar o habitat dos fungos, é importante considerar que diferentes fatores ambientais como temperatura, $\mathrm{pH}$, disponibilidade de água e oxigênio podem afetar diretamente o seu metabolismo (ESPOSITO;AZEVEDO, 2010). A produção de metabólitos primários e secundários promove adaptações evolutivas que, muitas vezes, servem de proteção para determinada espécie. O pigmento fúngico melanina é um exemplo de metabólito que contribui para a sobrevivência do esporo, protegendo-o contra a luz UV (CALVO et al., 2002).

Quando a concordância entre o ensaio em meio sólido e o método espectrofotométrico foi examinada, doze isolados apresentaram resultado negativo para a produção de L-Asparaginase em meio líquido, apesar da presença de significativos raios de zona avermelhada. Esse resultado foi semelhante ao encontrado por Lee e colaboradores (2005) e Theantana e colaboradores (2007) e já foi discutido em trabalho de Holker e colaboradores (2004), onde foi sugerido que a capacidade de algumas espécies fúngicas em produzir enzimas e outros produtos 
parece ser diferente em condições de estado sólido e de estado líquido (HOLKER; HOFER;LENZ, 2004; LEE et al., 2005; THEANTANA; HYDE;LUMYONG, 2007).

Outro fator que pode estar relacionado a essa discrepância entre a produção em meio sólido e em meio liquido é que, no meio sólido, o aumento de pH pode não estar relacionado à produção de L-Asparaginase. Outros metobólitos envolvidos em processos bioquímicos de crescimento dos micro-organismos podem estar relacionados com o aumento do $\mathrm{pH}$ do meio e, consequentemente, o aparecimento do halo vermelho ao redor da colônia (CALVO et al., 2002; ESPOSITO;AZEVEDO, 2010).

\subsection{MELHORAMENTO DA PRODUÇÃO DE L-ASPARAGINASE EM SHAKER}

Diferentes condições de cultivo foram avaliadas com o objetivo de melhorar a produção de L-Asparaginase em meio líquido. Neste capítulo, foram utilizadas as três cepas fúngicas, isoladas do bioma Cerrado, que apresentaram os maiores níveis de atividade enzimática em meio líquido (Tabela 15 e Figura 18). A cepa de $A$. terreus (PC-1.7.A), utilizada nos testes de padronização (metodologia e produção), também foi avaliada neste capítulo. 


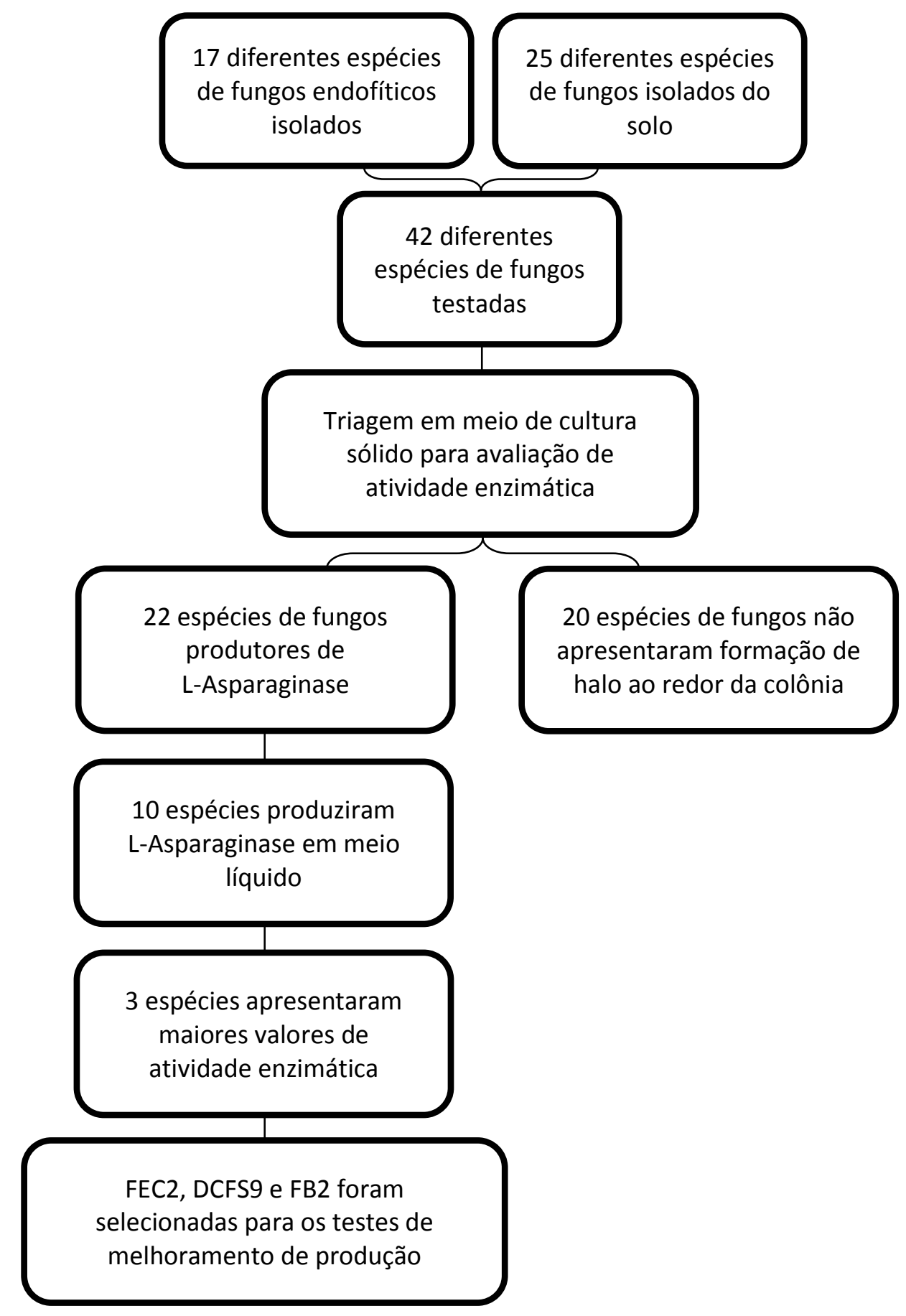

Figura 18 - Organograma geral dos fungos isolados do bioma Cerrado utilizados nesse trabalho.

Um estudo realizado por Rani e colaboradores (2012), que avaliou a produção de L-Asparaginase a partir de cepas fúngicas isoladas do solo, de diferentes regiões da Índia, indicou que os solos podem ser considerados ricas fontes de fungos produtores enzimáticos (RANI; SUNDARAM;VASANTHA, 2012). Theantana e colaboradores (2007) relataram a obtenção de cento e dezessete cepas fúngicas 
endofíticas a partir de apenas cinco espécies de plantas medicinais. O resultado encontrado pelos autores demonstra que quarenta e uma espécies produziram a enzima L-Asparaginase em meio sólido e, dessas, vinte e três apresentaram produção em meio líquido (THEANTANA; HYDE;LUMYONG, 2007).

Tabela 15 - Valores de atividade enzimática e origem das três cepas de fungos filamentosos, isoladas do bioma Cerrado da região Centro-Oeste brasileira, que apresentaram melhores níveis de atividade de L-Asparaginase.

\begin{tabular}{cccc}
\hline Origem & Identificação & Espécie & $\begin{array}{c}\text { Atividade } \\
\text { enzimática } \\
(\mathbf{U I} / \mathbf{m L})\end{array}$ \\
\hline $\begin{array}{c}\text { Cepa endofítica } \\
\text { (Eugenia dysenterica) }\end{array}$ & FEC2 & Guignardia mangiferae & 0,610 \\
$\begin{array}{c}\text { Cepa isolada solo } \\
\begin{array}{c}\text { Cepa endofítica } \\
(\text { Eugenia dysenterica })\end{array}\end{array}$ & DCFS 9 & Aspergillus sydowii & 0,131 \\
\hline${ }^{*}$ Não identificado & & $\mathrm{Nl}^{*}$ & 0,098 \\
\hline
\end{tabular}

Hymavathi e colaboradores (2009), em estudo que avaliou a produção da LAsparaginase utilizando Bacillus circulans, em fermentação em estado sólido, sugerem que a concentração de biomassa inicial de inóculo utilizada é um dos fatores mais importantes, necessitando de uma regulação muito fina para que ocorra uma produção efetiva da enzima (HYMAVATHI et al., 2009). Em outro trabalho, utilizando uma cepa de A. terreus (MTCC 1782), a otimização das condições de cultivo por fermentação submersa foi estudada objetivando a produção de LAsparaginase. Neste trabalho, os autores avaliaram, além de outros parâmetros, o tamanho do inóculo utilizado. A melhor produção enzimática ocorreu quando utilizouse um pré-inóculo, preparado em meio de cultura CDM, utilizando $1 \%(\mathrm{v} / \mathrm{v})$ de inóculo de esporos, com contagem de $2 \times 10^{7}-10^{8}$ esporos $/ \mathrm{mL}$ (GURUNATHAN;SAHADEVAN, 2012). Loureiro (2010), que em seu trabalho também utilizou a espécie $A$. terreus, relatou a utilização de um pré-inóculo para a produção de L-Asparaginase (LOUREIRO, 2010).

Diante dos trabalhos acima descritos, o primeiro parâmetro avaliado neste capítulo, frente a uma melhor produção enzimática, foi a realização de cultivos com 
e sem a utilização de pré-inóculo. Os resultados reforçam o que foi encontrado por Gurunathan e colaboradores (2012), demonstrando a importância da utilização do pré-inóculo durante o cultivo, elevando assim os níveis de produção enzimática (Figura 19).

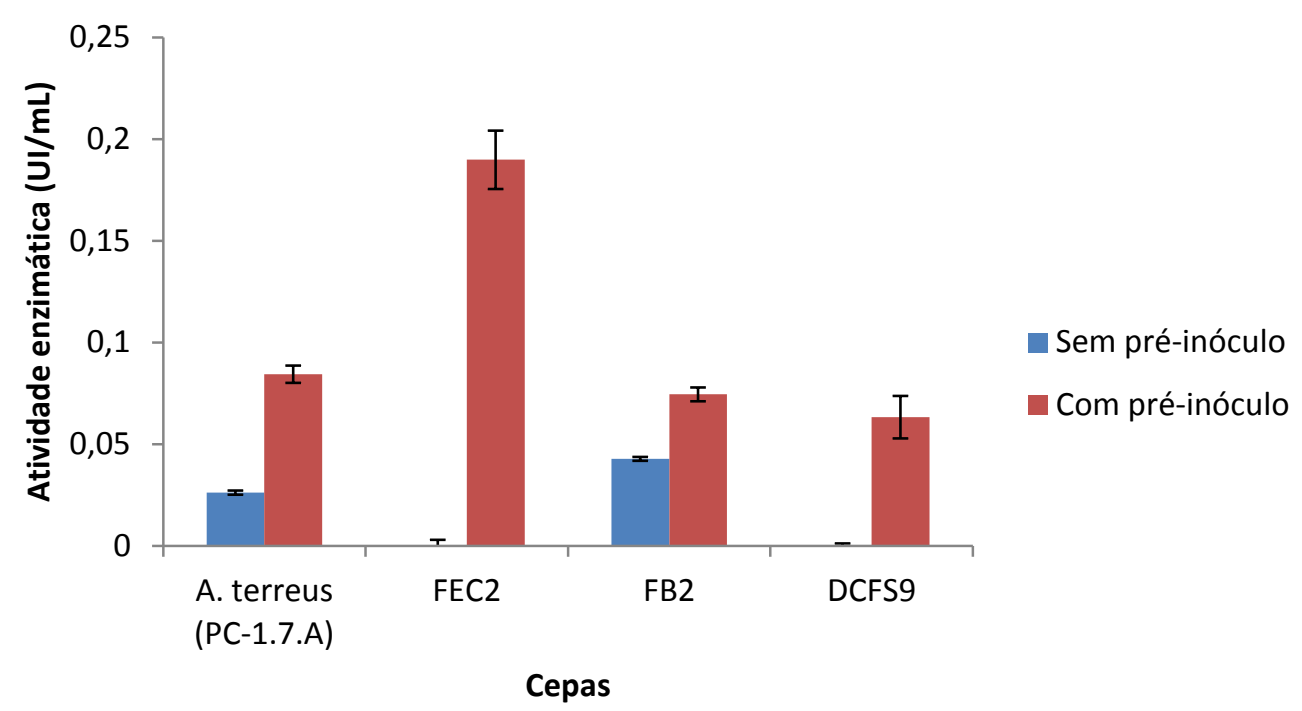

Figura 19 - Cultivos realizados a fim de avaliar a produção enzimática frente à utilização ou não de pré-inóculo.

Os resultados sugerem que a utilização de uma maior biomassa inicial do fungo parece ser efetiva para uma melhor produção de L-Asparaginase. Além disso, frente aos resultados encontrados, pode-se destacar ainda que, para duas cepas testadas (FEC2 e DCFS9), a utilização do pré-inóculo foi essencial para que a produção ocorresse.

$\mathrm{O}$ pH do meio de cultivo também parece influenciar a produção enzimática de L-Asparaginase em diferentes micro-organismos. Patro e colaboradores (2014) relatam que os valores máximos de atividade enzimática foram obtidos quando a espécie Aspergillus flavus foi cultivada em meio com pH 4,5 (PATRO et al., 2014). Estudos realizados com isolados da espécie Aspergillus niger divergem quanto ao pH ótimo de produção, variando de 6,5 até 8,0 (MISHRA, 2006; AKILANDESWARI; KAVITHA;VIJAYALAKSHMI, 2012; ZIA et al., 2013). Dados semelhantes foram encontrados a partir da utilização de Pseudomonas aeruginosa (EL-BESSOUMY; SARHAN;MANSOUR, 2004; PRADHAN; DASH;SAHOO, 2013). Pallem e colaboradores (2011), em estudo que avaliou a produção de L-Asparaginase a partir de Fusarium oxysporum, constataram que o $\mathrm{pH}$ 7,0 induziu melhores níveis de 
produção (PALLEM; NAGARJUN;SRIKANTH, 2011). Narayana e colaboradores (2008) relatam valores de $\mathrm{pH}$ entre 7,5 e 8,0 para as melhores produções de LAsparaginase utilizando Stretomyces albidoflavus (NARAYANA; KUMAR;VIJAYALAKSHMI, 2008), enquanto para Streptomyces gulbargensis, outros trabalhos relatam $0 \mathrm{pH} \quad 8,5$ como $\mathrm{pH}$ ótimo de produção (AMENA; VISHALAKSHI;PRABHAKAR, 2011).

Diante desses dados, fica claro que a alteração do pH inicial do meio de cultivo exerce grande influência na secreção de enzima. Assim, a produção de LAsparaginase sob diferentes valores de $\mathrm{pH}$ foi avaliada e os resultados estão mostrados na Figura 20.

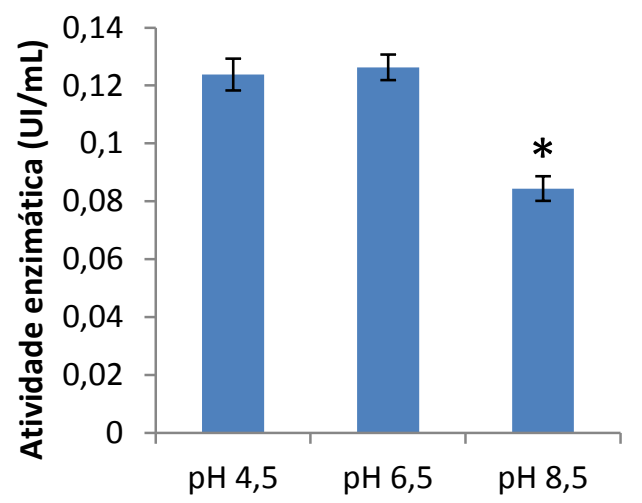

A. terreus (PC-1.7.A)

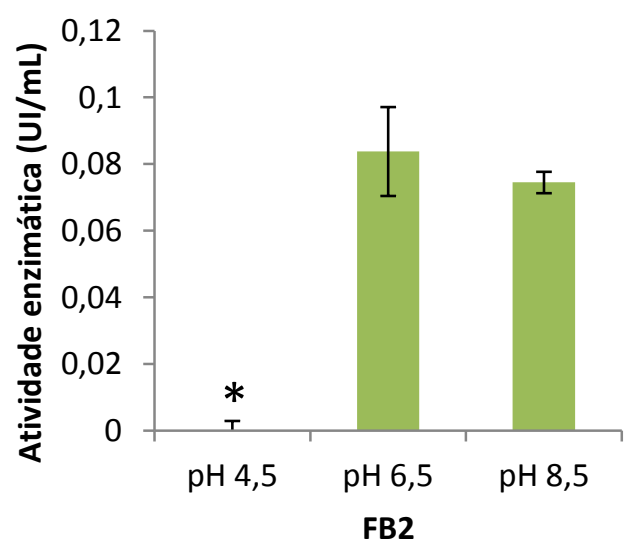

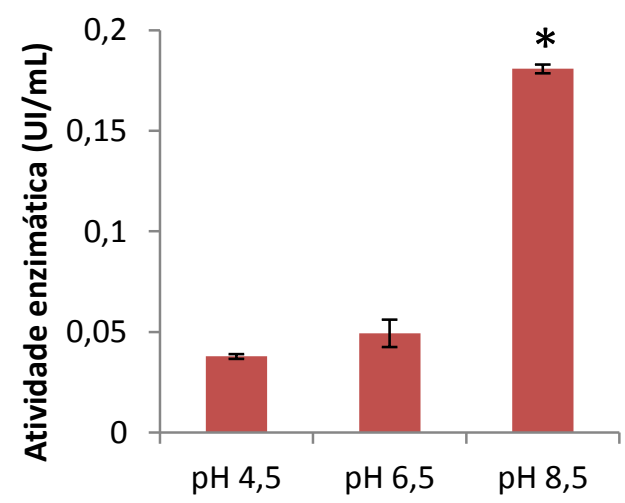

FEC2

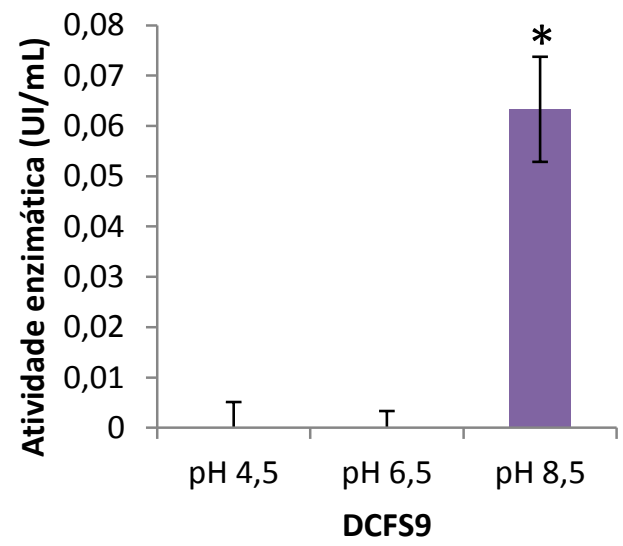

Figura 20 - Valores de atividade enzimática de quatro cepas fúngicas, em cultivos realizados em meios líquidos com diferentes valores iniciais de $\mathrm{pH}$.

Os resultados demonstram diferentes valores de $\mathrm{pH}$ ótimos de cultivo. Para a cepa de A. terreus (PC-1.7.A), o pH ótimo de cultivo, entre os três valores testados, foi na faixa ácida. Por outro lado, o pH 8,5 demonstra apresentar efeitos negativos 
sobre a produção. A cepa DCFS 9 apresentou melhor produção enzimática no meio de $\mathrm{pH}$ 8,5. As cepas endofíticas FEC2 e FB2 também apresentaram valores distintos de $\mathrm{pH}$ ótimo para a produção de L-Asparaginase. Enquanto a cepa FEC2 apresentou valores bem mais altos de produção no meio de $\mathrm{pH} 8,5$, o isolado FB2 apresentou valores de produção enzimática muito próximos quando comparados os meios de $\mathrm{pH} 6,5$ e 8,5 .

A produção de L-Asparaginase também foi avaliada frente a diferentes composições químicas dos meios de cultivo. Os macroelementos são essenciais na composição de meios de cultivo e compreendem àqueles elementos dos quais são necessárias maiores concentrações no meio, por exemplo, o carbono e o nitrogênio que, juntos com o hidrogênio, o oxigênio e em menor proporção o fósforo e 0 enxofre, participam da composição elementar da biomassa de todo ser vivo. Uma relação adequada de Carbono:Nitrogênio nos meios de cultivo é essencial para a área da tecnologia das fermentações (ESPOSITO;AZEVEDO, 2010).

A participação do carbono em alta porcentagem na composição da biomassa fúngica faz deste macroelemento o mais quantitativamente importante em um meio de cultivo (ESPOSITO;AZEVEDO, 2010). Assim, foram testadas duas fontes de carbono frente a produção de L-Asparaginase, a glicose e o amido. A utilização de amido em substituição à glicose parece exercer efeitos negativos durante a produção enzimática, nas quatro cepas testadas. Nenhuma das cepas apresentou atividade quando o amido foi utilizado, dados que divergem dos que foram relatados em estudos que utilizaram cepas de outras espécies do gênero Aspergillus, onde os valores máximos de atividade de L-Asparaginase foram encontrados em cultivos que continham essa fonte de carbono (AKILANDESWARI; KAVITHA;VIJAYALAKSHMI, 2012; PATRO et al., 2014).

Corroborando com os resultados encontrados neste trabalho, em estudo que utilizou A. terreus (MTCC 1782) para a produção enzimática de L-Asparaginase em estado sólido, foram relatados valores máximos de produção utilizando glicose como fonte de carbono (VARALAKSHMI;JAYA RAJU, 2013). Gurunathan e Sahadevan (2011), relataram que a glicose foi a melhor fonte de carbono para a produção máxima de L-Asparaginase em fermentações submersas, a partir de cultivos com a mesma cepa (GURUNATHAN;SAHADEVAN, 2011). Chankya Pallem e colaboradores (2011), relataram que a espécie Fusarium oxysporum também exibiu 
máxima produção de L-Asparaginase a partir da utilização de glicose como fonte de carbono (PALLEM; NAGARJUN;SRIKANTH, 2011).

$\mathrm{Na}$ composição elementar de uma célula fúngica, o macroelemento nitrogênio, juntamente com o carbono, é um dos elementos mais importantes (ESPOSITO;AZEVEDO, 2010). A fonte de nitrogênio presente no meio líquido de cultivo também parece exercer influência durante a produção de L-Asparaginase. As cepas FEC2, FB2 e DCFS 9 foram avaliadas quanto à produção de L-Asparaginase em meio que utilizou L-Asparagina em substituição a L-Prolina. Os resultados (Figura 21) relatam, assim como para $A$. terreus (PC-1.7.A), uma melhor produção durante a utilização de L-Prolina em cultivos com a cepa DCFS9. Enquanto isso, para as cepas endofíticas FEC2 e FB2, os valores de atividade enzimática foram muito semelhantes nos cultivos com L-Asparagina e L-Prolina, não apresentando diferença significativa entre eles.

Patro e colaboradores (2014) demonstraram que, durante a utilização de ácido glutâmico na composição do meio de cultivo, os valores de atividade aumentaram (PATRO et al., 2014). Assim, foram avaliadas produções a partir da incorporação deste ao meio contendo L-Prolina. Entretanto, os resultados relatam uma inibição da produção nas 4 cepas testadas (Figura 21). 

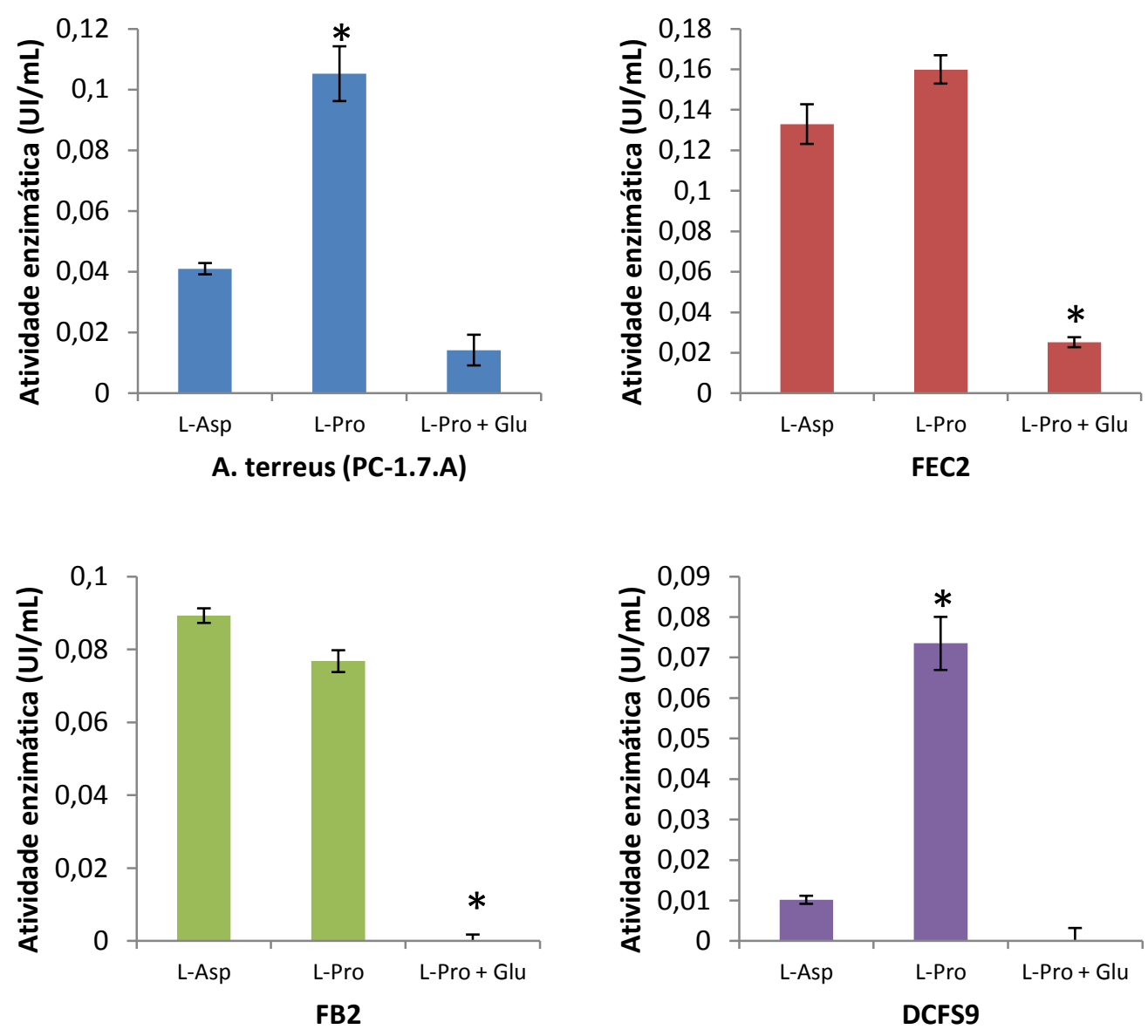

Figura 21 - Valores de atividade enzimática obtidos durante o cultivo em meio líquido, utilizando três fontes diferentes de nitrogênio.

A fonte de nitrogênio é um fator limitante em qualquer processo de fermentação e a produção enzimática de L-Asparaginase parece ser influenciada por este fator (PALLEM; NAGARJUN;SRIKANTH, 2011). Corroborando com os resultados encontrados neste estudo, muitos autores citam a L-Prolina como a melhor fonte de nitrogênio para a produção de L-Asparaginase a partir de diferentes espécies de fungos (AKILANDESWARI; KAVITHA;VIJAYALAKSHMI, 2012; TIPPANI;SIVADEVUNI, 2012; SARQUIS et al., 2004). Alguns estudos relatam a utilização de sulfato de amônio como positiva na produção de L-Asparaginase (GAFFAR;SHETHNA, 1977; VARALAKSHMI;JAYA RAJU, 2013) entretanto, este fator não foi estudado neste trabalho. 


\section{CONCLUSÕES}

Os resultados encontrados neste trabalho permitem as seguintes conclusões:

- A utilização da metodologia da Microplaca para determinação da atividade enzimática apresentou resultados de linearidade, precisão e exatidão dentro dos limites estabelecidos pela literatura oficial.

- O processo da diálise, utilizando membrana de celulose, mostrou-se adequado para a retirada de todo o interferente da amostra, proveniente do processo fermentativo.

- O bioma do Cerrado da região Centro-Oeste brasileira, demonstrou ser uma fonte rica de micro-organismos, tornando possível a obtenção de quarenta e duas cepas diferentes de fungos filamentosos, isoladas de diferentes regiões, incluindo dezessete espécies endofíticas, obtidas a partir de cinco espécies vegetais.

- Das quarenta e duas diferentes espécies de fungos filamentosos isolados do bioma Cerrado, vinte e duas indicaram a produção de L-Asparaginase em meio sólido e, dessas, dez produziram a enzima em meio líquido. Diante disso, pode-se concluir que a capacidade de algumas espécies fúngicas em produzir enzimas e outros produtos parece ser diferente em condições de estado sólido e de estado líquido.

- As diferentes fontes de carbono e nitrogênio utilizadas nos cultivos em meio líquido parecem ser determinantes para que se obtenham maiores níveis de produção de L-Asparaginase. Com relação às fontes de carbono, a utilização de glicose foi essencial para a produção enzimática, enquanto o amido parece exercer efeitos negativos. A L-Prolina parece ser a fonte de nitrogênio mais eficaz para que a produção enzimática ocorra em duas, das quatro cepas testadas. Já, a utilização do ácido glutâmico parece ocasionar efeitos contrários. 
- Faz-se necessário dar continuidade a este estudo, com a obtenção de novos isolados fúngicos e com a utilização de novas condições de cultivo para que se possam obter novas cepas produtoras, que apresentem melhores e mais constantes níveis de atividade enzimática.

- A utilização de outras metodologias para determinação da atividade enzimática de L-Asparaginase também se faz necessária, devido a falta de precisão e exatidão da própria técnica de Nesslerização. $O$ fato de que a reação, após a adição do reagente de Nessler, não apresenta um ponto final e que, a formação de um composto castanho alaranjado após a reação do reagente com a amônia livre pode se apresentar em solução coloidal e flocular, aumentam as chances de erros analíticos. Somam-se a isso, a formação de um complexo instável durante a reação da amônia livre com o reagente de Nessler, além de possíveis erros referentes à falta de experiência do operador. 


\section{REFERÊNCIAS BIBLIOGRÁFICAS}

ABIFINA. Associação Brasileira das Indústrias de Química Fina, Biotecnologia e suas Especialidades. Disponível em: www.abifina.org.br. Acesso: julho de 2013.

ADELMAN, A.; GROVES, F.; O'ROURKE, K.; SINHA, D.; HULSEY, T.; LAWSON, A.; WARTENBERG, D.; HOEL, D. Residential mobility and risk of childhood acute lymphoblastic leukaemia: an ecological study. British Journal of Cancer, v. 97, n. 1, p. $140-144,2007$.

AKILANDESWARI, K.; KAVITHA, K.; VIJAYALAKSHMI, M. Production of bioactive enzyme 1-asparaginase from fungal isolates of water sample through submerged fermentation. International Journal of Pharmacy and Pharmaceutical Sciences, v. 4, n. 4, p. 363-366, 2012.

AMENA, S.; VISHALAKSHI, N.; PRABHAKAR, M. Production, purification and characterization of L-asparaginase from Streptomyces gulbargensis. Brazilian Journal of Microbiology, v. 41, n. 1, p. 173-178, 2011.

ANDRADE, A.; BORGES, K.; SILVEIRA, V. Update on the Use of 1-Asparaginase in Infants and Adolescent Patients with Acute Lymphoblastic Leukemia. Clin Med Insights Oncol, v. 8, n., p. 95-100, 2014.

ASSELIN, B.; WHITIN, J.; COPPOLA, D.; RUPP, I.; SALLAN, S.; COHEN, H. Comparative Pharmacokinetic Studies of Three Asparaginase Preparations. Journal of Clinical Oncology, v. 11, n. 9, p. 1780-1786, 1993.

AVRAMIS, V.; SENCER, S.; PERICLOU, A.; SATHER, H.; BOSTROM, B.; COHEN, L.; ETTINGER, A.; ETTINGER, L.; FRANKLIN, J.; GAYNON, P.; HILDEN, J.; LANGE, B.; MAJLESSIPOUR, F.; MATHEW, P.; NEEDLE, M.; NEGLIA, J.; REAMAN, G.; HOLCENBERG, J. Arandomized comparison of native Escherichia coli asparaginase and polyethylene glycol conjugated asparaginase for treatment of children with newly diagnosed standard-risk acute lymphoblastic leukemia: a Children's Cancer Group study. Blood, v. 99, n. 6, p. 1986-1994, 2002.

BARBOSA, A. Recuperação de área degradada por mineração através da utilização de sementes e mudas de três espécies arbóreas do Cerrado, no Distrito Federal. 88 p. (Dissertação de mestrado) - Faculdade de Tecnologia, Departamento de Engenharia Florestal, Universidade de Brasília, Brasília, 2008.

BARROS, K. Sistema de duas fases aquosas napa/peg aplicado na purificação de proteases produzidas por fungos filamentosos. 89 p. (Tese de Doutorado) Programa de Pós-graduação em Ciências Farmacêuticas, Universidade de Brasília, Brasília, 2014. 
BEKKER-MÉNDEZ, V.; MIRANDA-PERALTA, E.; NÚÑEZ-ENRÍQUEZ, J.; OLARTECARRILLO, I.; GUERRA-CASTILLO, F.; POMPA-MERA, E.; OCAÑAMONDRAGÓN, A.; RANGEL-LÓPEZ, A.; BERNÁLDEZ-RÍOS, R.; MEDINASANSON, A.; JIMÉNEZ-HERNÁNDEZ, E.; AMADOR-SÁNCHEZ, R.; PEÑALOZA-GONZÁLEZ, J.; FLORES-CHAPA, J.; FAJARDO-GUTIÉRREZ, A.; FLORES-LUJANO, J.; RODRÍGUEZ-ZEPEDA, M.; DORANTES-ACOSTA, E.; BOLEA-MURGA， V.; NÚÑNEZ-VILLEGAS， N.; VELÁZQUEZ-AVIÑA， M.; TORRES-NAVA, J.; REYES-ZEPEDA, N.; GONZÁLEZ-BONILLA, C.; MEJÍAARANGURÉ, J. Prevalence of gene rearrangements in Mexican children with acute lymphoblastic leukemia: a population study-report from the Mexican Interinstitutional Group for the identification of the causes of childhood leukemia. Biomed Res Int, v. 2014, n., p. 1-8, 2014.

BELSON, M.; KINGSLEY, B.; HOLMES, A. Risk factors for acute leukemia in children: a review Environmental Health Perspectives, v. 115, n. 1, p. 138-145, 2007.

BENNETT, J. Mycotechnology: the role of fungi in biotechnology. J Biotechnol, v. 66, n. 23, p. 101-107, 1998.

BOROWITZ, M.; PULLEN, D.; WINICK, N.; MARTIN, P.; BOWMAN, W.; CAMITTA, B. Comparison of diagnostic and relapse flow cytometry phenotypes in childhood acute lymphoblastic leukemia: implications for residual disease detection: a report from the children's oncology group. Cytometry B Clin Cytom, v. 68, n. 1, p. 18-24, 2005.

BRADFORD, M. A rapid and sensitive method for the quantitation of microgram quantities of protein utilizing. The principle of protein-dye binding. Analytical Biochemistry, v. 72, n. 5, p. 278-254, 1976.

BRAKHAGE, A.; SCHROECKH, V. Fungal secondary metabolites - Strategies to activate silent gene clusters. Fungal Genet Biol, v. 48, n. 1, p. 15-22, 2011.

BRASIL. Ministério do Meio Ambiente. Instituto Brasileiro do Meio Ambiente e dos Recursos Naturais Renováveis. Monitoramento do Bioma Cerrado 2009-2010. Relatório Técnico não publicado. Brasília, p.1-65. 2011

. Agência Nacional de Vigilância Sanitária. RDC no 27, de 17 de maio de 2012. Dispõe sobre os requisitos mínimos para a validação de métodos bioanalíticos empregados em estudos com fins de registro e pós-registro de medicamentos. Brasília, p.1-12. 2012

BROMME, J. Evidence that the 1-asparaginase of guinea pig serum is responsible for its antilymphoma effects. I. Properties of the 1-asparaginase of guinea pig serum in 
relation to those of the antilymphoma substance. J Exp Med v. 118, n. 1, p. 99-120, 1963a.

. Evidence that the 1-asparaginase of guinea pig serum is responsible for its antilymphoma effects. II. Lymphoma 6C3HED cells cultured in a medium devoid of 1asparagine lose their susceptibility to the effects of guinea pig serum in vivo. J Exp Med, v. 118, n. 1, p. 121-148, 1963 b.

BROOME, J. D. Evidence that the L-asparaginase of guinea pig serum is responsible for its antilymphoma effects. I. Properties of the L-asparaginase of guinea pig serum in relation to those of the antilymphoma substance. Nature, v. 119, n., p. 1114-1115, 1961.

. Studies on the mechanism of tumor inhibition by L-asparaginase. Effects of the enzyme on asparagine levels in the blood, normal tissues, and 6C3HED lymphomas of mice: differences in asparagine formation and utilization in asparaginase-sensitive and -resistant lymphoma cells. Journal of Experimental Medicine, v. 127, n., p. 10551072, 1968.

BRUNTON, L. L.; LAZO, J. S.; PARKER, K. L. Goodman \& Gilman: As bases farmacológicas da terapêutica. $11^{\mathrm{a}} \mathrm{ed}$. Rio de Janeiro. 2010. 1844 p.

BUSHMAN, J.; PALMIERI, D.; WHINNA, H.; CHURCH, F. Insight into the mechanism of asparaginase-induced depletion of antithrombin III in treatment of childhood acute lymphoblastic leukemia. Leukemia Research, v. 24, n. 7, p. 559-565, 2000.

CALVO, A.; WILSON, R.; BOK, J.; KELLER, N. Relationship between Secondary Metabolism and Fungal Development. Microbiology and Molecular Biology Reviews, v. 66, n. 3, p. 447-459, 2002.

CAMARGO, B.; SANTOS, M.; REBELO, M.; REIS, R.; FERMAN, S.; NORONHA, C.; POMBO-DE-OLIVEIRA, M. Cancer incidence among children and adolescents in Brazil: first report of 14 population-based cancer registries. International Journal of Cancer, v. 126, n. 3, p. 715-720, 2010.

CANALlE, R.; BURIM, R.; TONE, L.; TAKAHASHI, C. Genetic Polymorphisms and Susceptibility to Childhood Acute Lymphoblastic Leukemia. Environmental and Molecular Mutagenesis v. 43, n. 2, p. 100-109, 2004.

CHAPLA, V.; BIASETTO, C.; ARAUJO, A. Fungos Endofíticos: Uma Fonte Inexplorada e Sustentável de Novos e Bioativos Produtos Naturais. Revista Virtual de Química, v. 5, n. 3, p. 421-437, 2013. 
CHEOK, M.; EVANS, W. Acute lymphoblastic leukaemia: a model for the pharmacogenomics of cancer therapy. Cancer, v. 6, n. 2, p. 117-227, 2006.

CHEOK, M.; LUGTHART, S.; EVANS, W. Pharmacogenomics of acute leukemia. Annu. Rev. Pharmacol. Toxicol., v. 46, n., p. 317-353, 2006.

CIMINO, G.; LO COCO, F.; BIONDI, A.; ELIA, L.; LUCIANO, A.; CROCE, C.; MASERA, G.; MANDELLI, F.; CANAANI, E. ALL-1 Gene at Chromosome 11q23 Is Consistently Altered in Acute Leukemia of Early Infancy. Blood, v. 82, n. 2, p. 544546, 1993.

CIUDAD, J.; SAN MIGUEL, J.; LOPEZ-BERGES, M.; VIDRIALES, B.; VALVERDE, B.; OCQUETEAU, M.; MATEOS, G.; CABALLERO, M.; HERNANDEZ, J.; MORO, M.; MATEOS, M.; ORFAO, A. Prognostic value of immunophenotypic detection of minimal residual disease in acute lymphoblastic leukemia. Journal of Clinical Oncology, v. 16, n. 12, p. 3774-3781, 1998.

COLEN, G. Isolamento e seleção de fungos filamentosos produtores de lipases. 206 p. (Tese de Doutorado) - Programa de Pós-graduação em Ciências de Alimentos, Universidade Federal de Minas Gerais, 2006.

CORTIJO-CASCAJARES, S.; JIMÉNEZ-CEREZO, M.; TEJADA, A. Revisión de las reacciones de hipersensibilidad a antineoplásicos. Farmacia Hospitalaria, v. 36, n. 3, p. 148-158, 2012.

COUSTAN-SMITH, E.; SONG, G.; CLARK, C.; KEY, L.; LIU, P.; MEHRPOOYA, M.; STOW, P.; SU, X.; SHURTLEFF, S.; PUI, C.; DOWNING, J.; CAMPANA, D. New markers for minimal residual disease detection in acute lymphoblastic leukemia. Blood v. 117, n. 23, p. 6267-6276, 2011.

DANIELS, J.; OLSHAN, A.; SAVITZ, D. Pesticides and childhood cancers. Environ Health Perspect, v. 105, n. 10, p. 1068-1077, 1997.

DEJONG, P. J. L-Asparaginase Production by Streptomyces griseus. Applied Microbiology v. 23, n. 6, p. 1163-1164, 1972.

DHALE, M. A.; MOHAN-KUMARI, H. P. A comparative rapid and sensitive method to screen L-asparaginase producing fungi. Journal of Microbiological Methods, v. 102, n., p. 66-68, 2014.

DHARMSTHITI, S. C.; LUECHAI, S. Purification and Characterization of Asparaginase from Solid State Culture of Aspergillus Niger AK10. International Journal of Biotechnology ando Biochemistry, v. 7, n. 1, p. 81-90, 2011. 
DIGIUSEPPE, J. Acute Lymphoblastic Leukemia: Diagnosis and Detection of Minimal Residual Disease Following Therapy. Clinics Laboratory Medicine, v. 27, n. 3, p. 533-549, 2007.

DRAINAS, C.; KINGHORN, J. R.; PATEMAN, J. A. Aspartic hydroxamate resistance and Asparaginase regulation in the fungus Aspergillus nidulans. Journal of General Microbiology, v. 98, n. 2, p. 493-501, 1977.

DRAINAS, D.; DRAINAS, C. A conductimetric method for assaying asparaginase activity in Aspergillus nidulans. Eur. J. Biochem., v. 151, n. 3, p. 591-593, 1985.

DUVAL, M.; SUCIU, S.; FERSTER, A.; RIALLAND, X.; NELKEN, B.; LUTZ, P.; BENOIT, Y.; ROBERT, A.; MANEL, A. M.; VILMER, E.; OTTEN, J.; PHILIPPE, N. Comparison of Escherichia coli-asparaginase with Erwinia-asparaginase in the treatment of childhood lymphoid malignancies: results of a randomized European Organisation for Research and Treatment of Cancer-Children's Leukemia Group phase 3 trial. Blood, v. 99, n. 8, p. 2734-2739, 2002.

EBRAHIMINEZHAD, A.; RASOUL-AMINI, S.; GHASEMI, Y. L-Asparaginase Production by Moderate Halophilic Bacteria Isolated from Maharloo Salt Lake. Indian Journal Microbiol, v. 51, n. 3, p. 307-311, 2011.

EL-BESSOUMY, A. A.; SARHAN, M.; MANSOUR, J. Production, isolation, and purification of L-asparaginase from Pseudomonas aeruginosa 50071 using solid-state fermentation. J Biochem Mol Biol, v. 37, n. 4, p. 387-393, 2004.

EL-NAGAR, N.; EL-EWASY, S.; EL-SHWEIHY, N. Microbial L-asparaginase as a Potential Therapeutic Agent for the Treatment of Acute Lymphoblastic Leukemia: The Pros and Cons. International Journal of Pharmacology, v. 10, n. 4, p. 182-199, 2014.

ESPOSITO, E.; AZEVEDO, J. Fungos: uma introdução à biologia, bioquímica e biotecnologia. Caxias do Sul: Editora da Universidade de Caxias do Sul-EDUCS. 2010. 638 p.

FAEDO, R.; BRIÃO, V.; CASTOLDI, S.; GIRARDELLI, L.; MILANI, A. Obtenção de leite com baixo teor de lactose por processos de separação por membranas associados à hidrólise enzimática. Revista CIATEC - UPF, v. 3, n. 1, p. 44-54, 2013.

FARINELLI, J. Avaliação, modificação e validação de metodologia para estudo de estabilidade de hidroquinona em creme. 98 p. (Dissertação de mestrado) Programa de pós-graduação em Ciências Farmacêuticas, UNIVERSIDADE ESTADUAL PAULISTA “JULIO DE MESQUITA FILHO”, Araraquara, 2008. 
FERNANDEZ, C.; CAI, X.; ELOZORY, A.; LIU, C.; PANETTA, J.; JEHA, S.; MOLINELLI, A.; RELLING, M. High-throughput asparaginase activity assay in serum of children with leukemia. Int J Clin Exp Med, v. 6, n. 7, p. 478-487, 2013.

FERRO, V. G.; DINIZ, I. R. Composição de espécies de Arctiidae (Insecta, Lepdoptera) em áreas de Cerrado. Revista Brasileira de Zoologia, v. 24, n. 3, p. 635-646, 2007.

FOON, K.; TODD, R. Immunologic Classification of Leukemia and Lymphoma. Blood, v. 68, n. 1, p. 1-31, 1986.

FUNARI, C.; FERRO, V. Uso ético da biodiversidade brasileira: necessidade e oportunidade. Revista Brasileira de Farmacognosia, v. 15, n. 2, p. 178-182, 2005.

GAFFAR, S.; SHETHNA, Y. Purification and Some Biological Properties of Asparaginase from Azotobacter vinelandii. Applied and Environmental Microbiology, v. 33, n. 3, p. 508-514, 1977.

GERBASE, A.; COELHO, F.; MACHADO, P.; FERREIRA, V. Gerenciamentos de resíduos químicos em instituições de ensino e pesquisa. Química Nova, v. 28, n. 1, p. 3-3, 2005.

GIL, E.; GARROTI, C.; CONCEIÇÃO, E.; SANTIAGO, M.; SOUZA, A. Aspectos técnicos e legais do gerenciamento de resíduos químico-farmacêuticos. Revista Brasileira de Ciências Farmacêuticas, v. 43, n. 1, p. 19-29, 2007.

GLASS, D.; GRAY, C.; JOLLEY, D.; GIBBONS, C.; SIM, M.; FRITSCHI, L.; ADAMS, G.; BISBY, J.; MANUELL, R. Leukemia Risk Associated With Low-Level Benzene Exposure. Epidemiology, v. 14, n. 5, p. 569-577, 2003.

GRAHAM, M. Pegaspargase: a review of clinical studies. Advanced Drug Delivery Reviews, v. 55, n. 10, p. 1293-1302, 2003.

GREAVES, M.; WIEMELS, J. Origins of chromosome translocations in childhood leukaemia. Nature Reviews Cancer, v. 3, n. 9, p. 639-649, 2003.

GRISI, P. Potencial alelopático de Sapindus saponaria L. (Sapindaceae). 127 p. (Dissertação de Mestrado) - Programa de Pós-graduação em Ecologia e Recursos Naturais, Universidade Federal de São Carlos, São Carlos, 2010.

GUILLEME, C.; DELGADO, R.; NAVARRO, J.; AGUIRRE, I.; SOLA, S.; CODINA, J.; SOLER, J.; RAMIREZ, L.; GARICANO, J.; MARTINEZ, B.; LOPES, L. 
Actualización del tratamiento con L-asparraginasa en Pediatría. An Pediatr (Barc), v. 79, n. 5, p. 329e321-329e311, 2013.

GULATI, R.; SAXENA, R. K.; GUPTA, R. A rapid plate assay for screnning L-Asparaginase producing micro-organisms. Letters in Applied Microbiology, v. 24, n. 1, p. 23-26, 1997.

GURUNATHAN, B.; SAHADEVAN, R. Design of Experiments and Artificial Neural Network Linked Genetic Algorithm for Modeling and Optimization of L-asparaginase Production by Aspergillus terreus MTCC 1782. Biotechnology and Bioprocess Engineering, v. 16, n. 1, p. 50-58, 2011.

Optimization of culture conditions and bench-scale production of L-asparaginase by submerged fermentation of Aspergillus terreus MTCC 1782. J Microbiol Biotechnol, v. 22, n. 7, p. 923-929, 2012.

HAGAG, A.; NOSAIR, N. Prognostic Impact of Neuropilin-1 Expression in Egyptian Children with B-lineage Acute Lymphoblastic Leukemia. Mediterr J Hematol Infect Dis, v. 7, n. 1, p. 1-6, 2015.

HARRIS, N.; JAFFE, E.; DIEBOLD, J.; FLANDRIN, G.; HERMELINK, K.; VARDIMAN, J.; LISTER, A.; BLOOMFIELD, C. World Health Organization Classification of Neoplastic Diseases of the Hematopoietic and Lymphoid Tissues: Report of the Clinical Advisory Committee Meeting-Airlie House, Virginia, November 1997. Journal of Clinical Oncology, v. 17, n. 12, p. 3835-3849, 1999.

HENZE, G. Early postinduction intensification therapy is essential in childhood acute lymphoblastic leukemia. Nature clinical practice oncology, v. 5, n. 9, p. 502-503, 2008.

HOLKER, U.; HOFER, M.; LENZ, J. Biotechnological advantages of laboratory-scale solidstate fermentation with fungi. Applied Microbiology and Biotechnology, v. 64, n. 2, p. $175-186,2004$.

HOLLIDAY, G. L.; MITCHELL, J. B. O.; THORNTON, J. M. Understanding the functional roles of amino acid residues in enzyme catalysis. J. Mol. Biol, v. 390, n. 1089-8638 (Electronic), p. 560-577, 2009.

HYMAVATHI, M.; SATHISH, T.; SUBBA RAO, C.; PRAKASHAM, R. Enhancement of LAsparaginase Production by Isolated Bacillus circulans (MTCC 8574) Using Response Surface Methodology. Appl Biochem Biotechnol, v. 159, n. 1, p. 191-198, 2009. 
IGARASI, S.; IMADA, A.; NAKAHAMA, K.; MATSUMOTO, T.; OOTSU, K. New antilymphoma L-asparaginase from fusarium species. Experientia, v. 30, n. 7, p. 814819, 1974.

IMADA, A.; IGARASI, S.; NAKAHAMA, K.; ISONO, M. Asparaginase and glutaminase activities of micro-organisms. Journal of General Microbiology, v. 76, n. 1, p. 8589, 1973.

JEHA, S.; PUI, C. Risk-adapted Treatment of Pediatric Acute Lymphoblastic Leukemia. Hematol Oncol Clin N Am, v. 23, n. 5, p. 973-990, 2009.

KAVITHA, A.; VIJAYALAKSHMI, M. A study on L-asparaginase of Nocardia levis MKVL_113. Scientific World Journal, v. 2012, n., p. 1-6, 2012.

KAWEDIA, J. D.; RYTTING, M. Asparaginase in Acute Lymphoblastic Leukemia. Clinical Lymphoma, Myeloma \& Leukemia, v. 14, n. S3, p. S14-S17, 2014.

KEBRIAEI, P.; ANASTAS, J.; LARSON, R. Acute lymphoblastic leukaemia: diagnosis and classification. Best Pract Res Clin Haematol, v. 15, n. 4, p. 597-621, 2003.

KERSEY, J. Fifty Years of Studies of the Biology and Therapy of Childhood Leukemia. Blood, v. 90, n. 11, p. 4243-4251, 1997.

KIDD, J. G. Regression of transplanted lymphomas induced in vivo by means of normal guinea pig serum. I. Course of transplanted cancers of various kinds in mice and rats given guinea pig serum, horse serum, or rabbit serum. Journal Experimental Medicine, v. 98, n., p. 565-581, 1953.

KLINK, C.; MACHADO, R. A conservação do Cerrado brasileiro. Megadiversidade, v. 1, n. 1, p. 147-155, 2005.

KUMAR, R.; DEVI, R. A.; NAIR, A.; BALAKRISHNAN, K. Stimulatory Effect of Acid Hydrolysed Okara Fortified with L-Asparagine on Fungal L-Asparaginase Production by Aspergillus Terreus MTCC 1782. Research Journal of Pharmaceutical, Biological and Chemical Sciences, v. 4, n. 2, p. 1458-1468, 2013.

KURTZBERG, J.; ASSELIN, B.; BERNSTEIN, M.; BUCHANAN, G. R.; POLLOCK, B. H.; CAMITTA, B. M. Polyethylene Glycol-conjugated L-asparaginase versus native Lasparaginase in combination with standard agents for children with acute lymphoblastic leukemia in second bone marrow relapse: a Children's Oncology Group Study (POG 8866). J Pediatr Hematol Oncol, v. 33, n. 8, p. 610-616, 2011. 
LEE, S.; NAKAJIMA, S.; IHARA, F.; KINOSHITA, H.; NIHIRA, T. Cultivation of Entomopathogenic Fungi for the Search of Antibacterial Compounds. Mycopathologia, v. 160, n., p. 321-325, 2005.

LEITE, E.; MUNIZ, M.; AZEVEDO, A.; SOUTO, F.; MAIA, A.; GONDIM, C.; BANDEIRA, F.; MELO, R. Fatores prognósticos em crianças e adolescentes com leucemia linfóide aguda. Rev. Bras. Saúde Matern. Infant, v. 7, n. 4, p. 413-421, 2007.

LOUREIRO, C. B. Purificação, conjugação e avaliação "in vitro" da atividade antineoplásica da L-asparaginase produzida por Aspergillus terreus (cepa PC1.7.A). 67 p. (Dissertação de mestrado) - Programa de Pós-graduação em Ciências Farmacêuticas, Universidade de São Paulo, Ribeirão Preto, 2010.

MACHADO, R.; RAMOS NETO, M.; PEREIRA, P.; CALDAS, E.; GONÇALVES, D.; SANTOS, N.; TABOR, K.; STEININGER, M. Estimativas de perda da área do Cerrado brasileiro. Relatório técnico não publicado. Conservação Internacional, Brasília, DF, p.1-23. 2004

MAHAJAN, R. V.; SARAN, S.; SAXENA, R. K.; SRIVASTAVA, A. K. A rapid, efficient and sensitive plate assay for detection and screening of 1-asparaginase-producing microorganisms. FEMS Microbiology Letters, v. 341, n. 2, p. 122-126, 2013.

MAZIERO, M.; BERSOT, L. Micotoxinas em alimentos produzidos no brasil. Revista Brasileira de Produtos Agroindustriais, v. 12, n. 1, p. 89-99, 2010.

MCNALLY, R.; EDEN, T. An infectious aetiology for childhood acute leukaemia: a review of the evidence. Br J Haematol, v. 127, n. 3, p. 243-263, 2004.

MENEGAUX, F.; BARUCHEL, A.; BERTRAND, Y.; LESCOEUR, B.; LEVERGER, G.; NELKEN, B.; SOMMELET, D.; HÉMON, D.; CLAVEL, J. Household exposure to pesticides and risk of childhood acute leukaemia. Occup Environ Med, v. 63, n. 2, p. 131-134, 2006.

MESQUITA, P. Bioprospecção de fungos endofíticos de Bauhinia variegata - busca por substâncias agonistas da isoforma gama do receptor ativado por proliferadores peroxissomais e por substâncias antioxidantes. 102 p. (Dissertação de mestrado) Programa de Pós-graduação em Ciências da Saúde, Universidade de Brasília, Brasília, 2011.

MEYER, V. Genetic engineering of filamentous fungi - Progress, obstacles and future trends. Biotechnol Adv, v. 26, n. 2, p. 177-185, 2008. 
MEYERS, N.; MITTERMEIER, R.; MITTERMEIER, C.; FONSECA, G.; KENT, J. Biodiversity hotspots for conservation priorities. Nature, v. 403, n. 6772, p. 852-858, 2000.

MISHRA, A. Production of L-Asparaginase, an Anticancer Agent, From Aspergillus niger Using Agricultural Waste in Solid State Fermentation. Applied Biochemistry and Biotechnology, v. 135, n. 1, p. 33-42, 2006.

MITTERMEIER, R.; MYERS, N.; THOMSEN, J.; FONSECA, G.; OLIVIERI, S. Biodiversity Hotspots and Major Tropical Wilderness Areas: Approaches to Setting Conservation Priorities. Conservation biology, v. 12, n. 3, p. 516-520, 1998.

MOHAN KUMAR, N. S.; MANONMANI, H. K. Purification, characterization and kinetic properties of extracellular L-asparaginase produced by Cladosporium sp. World J Microbiol Biotechnol, v. 29, n. 1573-0972 p. 577-587, 2013.

MOOLA, Z.; SCAWEN, M.; ATKINSON, T.; NICHOLLS, D. Erwinia chrysanthemi Lasparaginase: epitope mapping and production of antigenically modified enzymes. Biochem J, v. 302, n. Pt 3, p. 921-927, 1994.

MORAVEJI, S.; TORABI, A.; NAHLEH, Z.; FARRAG, S.; GAUR, S. Acute leukemia of ambiguous lineage with trisomy 4 as the sole cytogenetic abnormality: A case report and literature review. Leuk Res Rep, v. 3, n. 2, p. 33-35, 2014.

MULLER, H.; BOSS, J. Use of L-asparaginase in childhood ALL. Critical Reviews in Oncology/Hematology, v. 28, n. 2, p. 97-113, 1998.

NAIR, A.; KUMAR, R.; DEVI, R.; BALAKRISHNAN, K. Screening of commonly available solid process residues as substrate for L-asparaginase production by Aspergillus terreus MTCC 1782. Research Journal of Pharmaceutical, Biological and Chemical Sciences, v. 4, n. 2, p. 1731-1737, 2013.

NAKAHAMA, K.; IMADA, A.; IGARASI, S.; TUBAKI, K. Formation of L-Asparaginase by Fusarium Species. Journal of General Microbiology, v. 75, n. 2, p. 269-273, 1973.

NAKASONE, K.; PETERSON, A.; JONG, S. Preservation and distribution of fungal cultures. In: G. MUELLER; G. BILLSM. FOSTER (Ed.). Biodiversity of fungi, inventory and monitoring methods. San Diego: Elsevier Academic Press, 2004. Preservation and distribution of fungal cultures, p.37-47

NARAYANA, K. J.; KUMAR, K. G.; VIJAYALAKSHMI, M. L-asparaginase production by Streptomyces albidoflavus. Indian J Microbiol, v. 48, n. 3, p. 331-336, 2008. 
NARAZAKI, H.; KAIZU, K.; MIYATAKE, C.; KOIZUMI, S.; ASANO, T.; FUJINO, O. Delayed-type Hypersensitivity in Response to L-asparaginase in a Case of Acute Lymphoblastic Leukemia. J Nippon Med Sch, v. 79, n. 6, p. 489-493, 2012.

NARTA, U. K.; KANWAR, S. S.; AZMI, W. Pharmacological and clinical evaluation of 1asparaginase in the treatment of leukemia. Critical Reviews in Oncology/Hematology, v. 61, n. 3, p. 208-221, 2007.

NEHMY, R.; BRITO, A.; MOTA, J.; OLIVEIRA, B. A perspectiva dos pais sobre a obtenção do diagnóstico de leucemia linfóide aguda em crianças e adolescentes: uma experiência no Brasil. Rev Bras Saúde Matern Infant, v. 11, n. 3, p. 293-299, 2011.

NELSON, D.; COX, M. Lehninger: Princípios de Bioquímica. São Paulo: Sarvier. 2002. $1009 \mathrm{p}$.

NERY, F. Aspectos da germinação, armazenamento de sementes, crescimento inicial e anatomia de plantas jovens de Calophyllum brasiliense Cambess. 173 p. (Dissertação de mestrado) - Programa de Pós-graduação em Agronomia, Universidade Federal de Lavras, Lavras, 2006.

NIHARIKA YADAV, C.; SARKAR, S. Production of L-Asparaginase By Fusarium Oxysporum Using Submerged Fermentation. International Journal of Pharmaceutical Science Invention, v. 3, n. 6, p. 32-40, 2014.

NOMME, J.; SU, Y.; KONRAD, M.; LAVIE, A. Structures of apo and product-bound human L-asparaginase: insights into the mechanism of autoproteolysis and substrate hydrolysis. Biochemistry, v. 51, n. 34, p. 6816-6826, 2012.

NOSHCHENKO, A.; MOYSICH, K.; BONDAR, A.; ZAMOSTYAN, P.; DROSDOVA, V.; MICHALEK, A. Patterns of acute leukaemia occurence among children in the Chernobyl region. International Journal of Epidemiology, v. 30, n. 1, p. 125-129, 2001.

ONCIU, M. Acute lymphoblastic leukemia. Hematol Oncol Clin N Am v. 23, n. 4, p. 655674, 2009.

ORLANDELLI, R.; SPECIAN, V.; FELBER, A.; PAMPHILE, J. Enzimas de interesse industrial: Produção por fungos e aplicações. Rev. Saúde e Biol., v. 7, n. 3, p. 97-109, 2012. 
PADJAK, E.; PADJAK, W. A simple and sensitive method for detection of L-asparaginase by polyacrylamide gel electrophoresis. Analytical Biochemistry, v. 50, n. 1, p. 317320, 1972.

. Activity stain for the detection of L-asparaginase - Anti-L-asparaginase complexes in agar. Journal of Immunological Methods, v. 6, n. 1-2, p. 109-114, 1974.

PALLEM, C.; NAGARJUN, V.; SRIKANTH, M. Production of a tumor inhibitory enzyme, L-asparaginase through solid state fermentation using Fusarium oxysporum. International Journal of Pharmaceutical Sciences Review and Research, v. 7, n. 2, p. 189-192, 2011.

PAN, Y.; CHEN, H.; LIANG, H.; WANG, X.; WANG, L. Meta-analysis of the association between CCAAT/enhancer binding protein- $\varepsilon$ polymorphism and the risk of childhood acute lymphoblastic leukemia. Int J Clin Exp Med, v. 7, n. 12, p. 5553-5557, 2014.

PANOSYAN, E.; SEIBEL, N.; MARTIN-ARAGON, S.; GAYNON, P.; AVRAMIS, I.; SATHER, H.; FRANKLIN, J.; NACHMAN, J.; ETTINGER, L.; LA, M.; STEINHERZ, P.; COHEN, L.; SIEGEL, S.; AVRAMIS, V. Asparaginase Antibody and Asparaginase Activity in Children With Higher-Risk Acute Lymphoblastic Leukemia. J Pediatr Hematol Oncol, v. 26, n. 4, p. 217-226, 2004.

PATRO, K.; BASAK, U.; MOHAPATRA, A.; GUPTA, N. Development of new medium composition for enhanced production of L-Asparaginase by Aspergillus flavus. Journal of environmental biology, v. 35, n. 1, p. 295-300, 2014.

PIETERS, R.; HUNGER, S. P.; BOOS, J.; RIZZARI, C.; SILVERMAN, L.; BARUCHEL, A.; GOEKBUGET, N.; SCHRAPPE, M.; PUI, C. H. L-asparaginase treatment in acute lymphoblastic leukemia: a focus on Erwinia asparaginase. Cancer, v. 117, n. 2, p. 238-249, 2011.

PRADHAN, B.; DASH, S.; SAHOO, S. Optimization of some physical and nutritional parameters for the production of L-asparaginase by isolated thermophilic Pseudomonas aeruginosa strain F1. Biosciences Biotechnology Research Asia, v. 10, n. 1, p. 389-395, 2013.

PUI, C.; CAMPANA, D.; EVANS, W. Childhood acute lymphoblastic leukaemia - current status and future perspectives. Lancet Oncol, v. 2, n. 10, p. 597-607, 2001.

PUI, C.; THIEL, E. Central Nervous System Disease in Hematological Malignancies: Historical Perspective and Practical Applications. Semin Oncol, v. 36, n. 4, p. S2-S16, 2009. 
PUI, C. H.; EVANS, W. E. Treatment of Acute Lymphoblastic Leukemia. The new england journal o f medicine, v. 354, n. 2, p. 166-178, 2006.

PUI, C. H.; RELliNG, M. V.; DOWNING, J. R. Acute Lymphoblastic Leukemia. The new england journal of medicine, v. 350, n. 15, p. 1535-1548, 2004.

QUEIROZ, F. Impactos da sojicultura de exportação sobre a biodiversidade do Cerrado. Sociedade \& Natureza, v. 21, n. 2, p. 193-209, 2009.

QUINTANILLA-FLORES, D.; FLORES-CABALLERO, M.; RODRÍGUEZ-GUTIÉRREZ, R.; TAMEZ-PÉREZ, H.; GONZÁLEZ-GONZÁLEZ, J. Acute Pancreatitis and Diabetic Ketoacidosis following L-Asparaginase/Prednisone Therapy in Acute Lymphoblastic Leukemia. Case Rep Oncol Med, v. 2014, n., p. 1-3, 2014.

RAJASEKARAN， R.; CHANDRASEKARAN， R.; MUTHUSELVAM， M. Microbial biotechnology: Rapid Advances in an area of massive impact. Advanced BioTech, v. 7, n. 6, p. 19-25, 2008.

RAMYA, L.; DOBLE, M.; REKHA, V.; PULICHERLA, K. L-Asparaginase as Potent Antileukemic Agent and Its Significance of Having Reduced Glutaminase Side Activity for Better treatment of Acute Lymphoblastic Leukaemia. Appl Biochem Biotechnol, v. 167, n. 8, p. 2144-2159, 2012.

RANI, S.; SUNDARAM, L.; VASANTHA, P. Isolation and screening of L-asparaginase producing fungi from soil samples. International Journal of Pharmacy and Pharmaceutical Sciences, v. 4, n. 1, p. 279-282, 2012.

RICHARDS, N. G.; KILBERG, M. S. Asparagine synthetase chemotherapy. Annu Rev Biochem, v. 75, n., p. 629-654, 2006.

RIZZARI, C.; CONTER, V.; STARY, J.; COLOMBINI, A.; MOERICKE, A.; SCHRAPPE, M. Optimizing asparaginase therapy for acute lymphoblastic leukemia. Curr Opin Oncol, v. 25, n. 1, p. S1-S9, 2013.

SAISON, J.; BERGER, F.; LEBOSSE, F.; AUDOUAL, R.; THOMAS, X.; MICHALLET, M. Hepatomegaly and fever at the time of neutrophil recovery revealing L-asparaginase toxicity in the treatment of acute lymphoblastic leukemia. Am J Case Rep, v. 15, n. 1, p. 13-17, 2014.

SARQUIS, M. I.; OLIVEIRA, E. M.; SANTOS, A. S.; COSTA, G. L. Production of Lasparaginase by filamentous fungi. Mem Inst Oswaldo Cruz, v. 99, n. 5, p. 489-492, 2004. 
SCHEETZ, R.; WHELAN, H.; WRISTON, J. Purification and properties of an Lasparaginase from Fusarium tricinctum. Arch Biochem Biophys, v. 142, n. 1, p. 184189, 1971.

SCHOCH, C.; HAFERLACH, T.; HAASE, D.; FONATSCH, C.; LOEFFLER, H.; SCHLEGELBERGER, B.; STAIB, P.; SAUERLAND, M.; HEINECKE, A.; BUECHNER, T.; HIDDEMANN, W. Patients with de novo acute myeloid leukaemia and complex karyotype aberrations show a poor prognosis despite intensive treatment: a study of 90 patients. British Journal of Haematology, v. 112, n. 1, p. 118-126, 2001.

SHRIVASTAVA, A.; KHAN, A.; KHURSHID, M.; KALAM, M.; JAIN, S.; SINGHAL, P. Recent developments in L-asparaginase discovery and its potential as anticancer agent. Critical Reviews in Oncology/Hematology, v., n., p. 2015.

SHRIVASTAVA, A.; KHAN, A.; SHRIVASTAV, A.; JAIN, S.; SINGHAL, P. Kinetic Studies of L-Asparaginase From Penicillium digitatum. Preparative Biochemistry \& Biotechnology, v. 42, n. 6, p. 574-581, 2012.

SILVA, S. Avaliação da atividade antimicrobiana de espécies vegetais do bioma Cerrado. 113 p. (Dissertação de mestrado) - Programa de Pós-graduação em Ciências Farmacêuticas, Universidade de Brasília, Brasília, 2013.

SINGH, Y.; SRIVASTAV, S. Statistical and evolutionary optimization for enhanced production of an antileukemic enzyme, L-asparaginase, in a protease-deficient Bacillus aryabhattai ITBHU02 isolated from the soil contaminated with hospital waste. Indian J Exp Biol, v. 51, n. 4, p. 322-335, 2013.

SIQUEIRA, F. Resíduos agroindustriais com potencial para a produção de holocelulases de origem fúngica e aplicações biotecnológicas de hidrolases. $277 \mathrm{p}$. (Tese de Doutorado) - Programa de Pós-graduação em Ciências Biológicas - Biologia Molecular, Universidade de Brasília, Brasília, 2010.

SOBOPE. Sociedade Brasileira de Oncologia Pediátrica. Disponível em : http://www.sobope.org.br. Acesso em: fevereiro de 2013, 2013.

SOUZA, A.; SOUZA, A.; ASTOLFI FILHO, S.; BELÉM PINHEIRO, M.; SARQUIS, M.; PEREIRA, J. Atividade antimicrobiana de fungos endofíticos isolados de plantas tóxicas da amazônia: Palicourea longiflora (aubl.) rich e Strychnos cogens bentham. ACTA Amazonica, v. 34, n. 2, p. 185-195, 2004. 
SUN, R.; GAO, Y.; SHEN, K.; XU, Y.; WANGA, C.; LIU, H.; DONG, J. Antimicrobial metabolites from the aquatic fungus Delitschia corticola. Phytochemistry Letters, v. 4, n. 2, p. 101-105, 2011.

TALLURI, V.; BHAVANA, M.; MAHESH KUMAR, M.; RAJAGOPAL, S. L-asparaginase: An ultimate anti-neoplastic enzyme. International Letters of Natural Sciences, v. 10, n., p. 23-25, 2014.

THEANTANA, T.; HYDE, K.; LUMYONG, S. Asparaginase production by endophytic fungi isolated from thai medicinal plants. KMITL Sci. Tech. J. , v. 7, n. S1, p. 13-18, 2007.

THIRUNAVUKKARASU, $\quad$ N.; $\quad$ SURYANARAYANAN, $\quad$ T.; $\quad$ MURALI, $\quad$ T.; RAVISHANKAR, J.; GUMMADI, S. Lasparaginase from marine derived fungal endophytes of seaweeds. Mycosphere, v. 2, n. 2, p. 147-155, 2011.

TIPPANI, R.; SIVADEVUNI, G. Nutritional factors effecting the production of Lasparaginase by the Fusarium sp. African Journal of Biotechnology, v. 11, n. 15, p. 3692-3696, 2012.

TONG, W.; PIETERS, R.; TISSING, W.; VAN DER SLUIS, I. Should we use a desensitization protocol in acute lymphoblastic leukemia patients with silent inactivation of PEGasparaginase? Haematologica, v. 99, n. 1, p. 1-32, 2014.

USHA, R.; MALA, K. K.; VENIL, C. K.; PALANISWAMY, M. Screening of Actinomycetes from mangrove ecosystem for L-asparaginase activity and optimization by response surface methodology. Polish journal of microbiology, v. 60, n. 3, p. 213-221, 2011.

VAN DER SLUIS, I.; MÖRICKE, A.; ESCHERICH, G.; STACKELBERG, A.; HOLTER, W.; KLINGEBIEL, T.; FLOTHO, C.; LEGIEN, S.; TISSING, W.; BIERINGS, M.; GUIMBAL-SCHMOLCK, C.; PICHLMEIER, U.; KÜHNEL, H.; PIETERS, R. Efficacy and safety of recombinant $E$. coli-asparaginase in infants (less than one year of age) with acute lymphoblastic leukemia. Hematologica, v. 98, n. 11, p. 1697-1701, 2013.

VARALAKSHMI, V.; JAYA RAJU, K. Optimization of L-asparaginase production by Aspergillus terreus MTCC 1782 using bajra seed flour under solid state fermentation. International Journal of Research in Engineering and Technology, v. 2, n. 9, p. 121-129, 2013.

VILELA, E.; CARVALHO, T.; DUARTE, A.; NAVES, R.; SANTOS, S.; SERAPHINC, J.; FERRI, P. Spatial Structure of Eugenia dysenterica Based on Essential Oil Chemovariations and Implications for Conservation and Management of the Genetic Diversity of its Populations. J. Braz. Chem. Soc., v. 23, n. 10, p. 1776-1782, 2012. 
VOGEL, A. Química Analítica Qualitativa. São Paulo: Mestre Jou. 1981. 665 p.

WANG, J.; DICK, J. Cancer stem cells: lessons from leukemia. Trends in Cell Biology, v. 15, n. 9, p. 494-501, 2005.

WEI, D. Z.; LIU, H. Promotion of L-asparaginase production by using $\mathrm{n}$-dodecane. Biotechnology Techniques, v. 12, n. 2, p. 129-131, 1998.

WINK, P. L. Produção da enzima antileucêmica L-Asparaginase II a partir da clonagem do gene ErA de Erwinia carotovora supsp. atroseptica em Escherichia coli. 53 p. (Dissertação de mestrado) - Pós-Graduação em Medicina e Ciências da Saúde, Pontifícia Universidade Católica do Rio Grande do Sul, Porto Alegre, 2009.

YELLIN, T.; WRISTON JR, J. Antagonism of Purified Asparaginase from Guinea Pig Serum toward Lymphoma. Science, v. 151, n. 3713, p. 998-1004, 1966.

YUE, Q.; LIU, X.; CHEN, L.; LIU, Z.; CHEN, W. T-cell acute lymphoid leukemia resembling Burkitt leukemia cell morphology: A case report. ONCOLOGY LETTERS v. 9, n. 3, p. 1236-1238, 2015.

ZANROSSO, C.; HATAGIMA, A.; EMERENCIANO, M.; RAMOS, F.; FIGUEIREDO, A.; FÉLIX, T.; SEGAL, S.; GUIGLIANI, R.; MUNIZ, M.; POMBO-DE-OLIVEIRA, M. The role of methylenetetrahydrofolate reductase in acute lymphoblastic leukemia in a Brazilian mixed population. Leukemia Research, v. 30, n. 4, p. 477-481, 2006.

ZIA, M.; BASHIR, R.; AHMED, I.; IFTIKHAR, T. Production of L-Asparaginase from Aspergillus Niger using Agro Wastes By-Products in Submerged Fermentation Process. Jurnal Teknologi v. 62, n. 2, p. 47-51, 2013.

ZIMMER, K.; BORRÉ, G.; TRENTIN, D.; WOICICKOSKI JR, C.; FRASSON, A.; GRAEFF, A.; GOMES, P.; MACEDO, A. Enzimas microbianas de uso terapêutico e diagnóstico clínico. Revista Liberato, v. 10, n. 14, p. 123-137, 2009. 